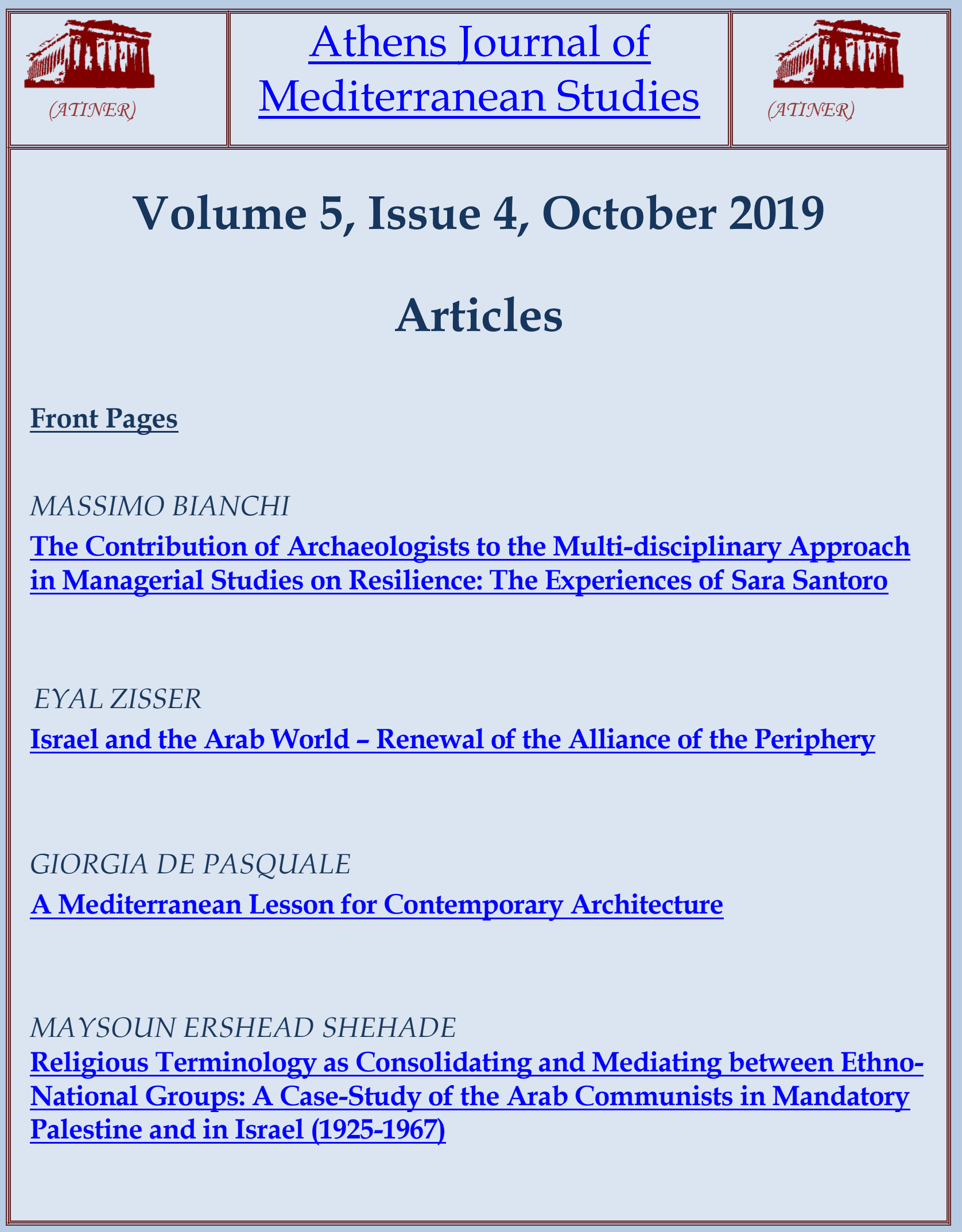




\section{Mission}

ATINER is a World Non-Profit Association of Academics and Researchers based in Athens. ATINER is an independent Association with a Mission to become a forum where Academics and Researchers from all over the world can meet in Athens, exchange ideas on their research and discuss future developments in their disciplines, as well as engage with professionals from other fields. Athens was chosen because of its long history of academic gatherings, which go back thousands of years to Plato's Academy and Aristotle's Lyceum. Both these historic places are within walking distance from ATINER's downtown offices. Since antiquity, Athens was an open city. In the words of Pericles, Athens"... is open to the world, we never expel a foreigner from learning or seeing". ("Pericles' Funeral Oration", in Thucydides, The History of the Peloponnesian War). It is ATINER's mission to revive the glory of Ancient Athens by inviting the World Academic Community to the city, to learn from each other in an environment of freedom and respect for other people's opinions and beliefs. After all, the free expression of one's opinion formed the basis for the development of democracy, and Athens was its cradle. As it turned out, the Golden Age of Athens was in fact, the Golden Age of the Western Civilization. Education and (Re)searching for the 'truth' are the pillars of any free (democratic) society. This is the reason why Education and Research are the two core words in ATINER's name. 
The Athens Journal of Mediterranean Studies ISSN NUMBER: 2241-794X- DOI: 10.30958/ajms Volume 5, Issue 4, October 2019

Download the entire issue ( $\underline{\mathrm{PDF}})$

Front Pages $\quad$ i-x

The Contribution of Archaeologists to the Multi- 207 disciplinary Approach in Managerial Studies on

Resilience: The Experiences of Sara Santoro

Massimo Bianchi

Israel and the Arab World - Renewal of the Alliance of 225 the Periphery

Eyal Zisser

A Mediterranean Lesson for Contemporary Architecture

Giorgia De Pasquale

Religious Terminology as Consolidating and Mediating 263 between Ethno-National Groups: A Case-Study of the Arab Communists in Mandatory Palestine and in Israel (1925-1967)

Maysoun Ershead Shehade 


\section{Athens Journal of Mediterranean Studies Editorial and Reviewers' Board}

\section{$\underline{\text { Editors }}$}

- Dr. Gregory T. Papanikos, President, ATINER (Economics).

- Dr. Yannis Stivachtis, Director, Center for European \& Mediterranean Affairs (CEMA) \& Director, International Studies Program Virginia Tech-Virginia Polytechnic Institute \& State University, USA (Politics \& International Affairs).

- Dr. Nicholas Pappas, Vice President of Academic Membership, ATINER \& Professor of History, Sam Houston University, USA (History).

\section{Editorial Board}

- Dr. Albert W. Harris, Professor Emeritus, Department of Politics, Humboldt State University, USA.

- Dr. Ken Roberts, Emeritus Professor, School of Sociology and Social Policy, University of Liverpool, UK.

- Dr. Emmanuel Sivan, Professor Emeritus of History, Hebrew University of Jerusalem, Israel.

- Dr. Daniel Kent Neil Johnson, Associate Chair of the Department, Professor of Economics, Editor-inChief of Lightning Abstracts, Colorado College Department of Economics and Business, USA.

- Dr. Arthur Chen, Academic Member, ATINER \& Director, Center for World Heritage Studies, School of Architecture, University of Minnesota, USA.

- Dr. Javier González Rosas, Director of Socio economic Studies and International Migration, National Population Council, Mexico.

- Dr. Richard Wittorski, Director, ESPE Academy, University of Rouen, France.

- Dr. Aieman Ahmad Al-Omari, Professor, Hashemite University, Jordan.

- Dr. Gustavo Araujo Batista, Academic Member, ATINER \& Professor, University of Uberaba (UNIUBE) \& Social Sciences College, Brazil.

- Dr. Dilek Barlas, Professor, Koç University, Turkey.

- Dr. Jesus Gaston Gutierrez Cedillo, Professor, Autonomy University of Estado, Mexico.

- Dr. Fadel Djamel, Professor, University of Souk Ahras Mohamed Cherif Messaadia, Algeria.

- Dr. Alka Obadic, Academic Member, ATINER \& Full Professor, Department of Macroeconomics and Economic Development, University of Zagreb, Croatia.

- Dr. Maria Urma, Professor, University of Art "George Enescu", Romania.

- Dr. Mario Esteban Cunsulo, Professor, National University of San Juan, Argentina.

- Dr. Montezanti Miguel Angel, Associate Professor, National University of La Plata, Argentina.

- Dr. Abdelkader Derbali, Academic Member, ATINER \& Associate Professor, Higher Institute of Management of Sousse, Tunisia.

- Dr. Ulku Doganay, Academic Member, ATINER \& Associate Professor, Ankara University, Turkey.

- Dr. Ulas Basar Gezgin, Associate Professor in Applied Communication, Turkey, Lecturer in Business \& Management, British University Vietnam (Hanoi), Vietnam.

- Dr. Anabela Gradim, Professor \& Researcher, University of Beira Interior, Portugal.

- Dr. Mohinder Partap Satija, Professor, Department of Library and Information Science, Guru Nanak Dev University, India.

- Dr. Eduardo Segarra, Academic Member, ATINER \& Professor, Department of Agricultural \& Applied Economics, Texas Tech University, USA.

- Dr. Jane Bristol-Rhys, Associate Professor, College of Sustainability Sciences and Humanities, Zayed University, United Arab Emirates.

- Dr. Essam Gouda, Associate Professor, AlAzhar University, Egypt.

- Dr. Andrej Grubacic, Associate Professor, California Institute of Integral Studies, USA.

- Dr. Lamia Jamel, Academic Member, ATINER \& Associate Professor in the Faculty of Economic Sciences and Management, University of Sousse, Tunisia. 
- Dr. Hiteshkumar Parmar, Academic Member, ATINER \& Associate Professor, P. D. Malaviya College of Commerce, India.

- Dr. Donizete Rodrigues, Associate Professor, University of Beira Interior, Portugal.

- Dr. Lehte Roots, Associate Professor, Chair of The Public Law, Tallinn University of Technology, Estonia.

- Dr. Tatiana Smetanina, Associate Professor, Institute of Economics and Management, Udmurt State University, Russia.

- Dr. Anna Svirina, Associate Professor \& Head, Economics and Management Department, Kazan National Research Technical University, Russia.

- Dr. Iman A. Hamdy Editor, Adjunct Assistant Professor, Political Science Department, The American University in Cairo, Egypt.

- Dr. Hakim Ajhar, Assistant Professor, Department of Humanities and Social Sciences, Khalifa University, United Arab Emirates.

- Dr. Zeynep Akture, Academic Member, ATINER \& Assistant Professor, Department of Architecture, Izmir Institute of Technology, Turkey.

- Dr. Aijaz Ashraf Wani, Senior Assistant Professor, Department of Political Science, University of Kashmir, India.

- Dr. Methiye Gul Coteli, Assistant Professor, Department of City and Regional Planning, Erciyes University, Turkey.

- Dr. Fatma Gürses, Academic Member, ATINER \& Assistant Professor, Faculty of Communication, Journalism Kastamonu University, Turkey.

- Dr. Jülide Karakoç, Associate Professor, Altinbas University, Istanbul, Turkey.

- Dr. Levent Kirval, Assistant Professor, Istanbul Technical University, Turkey.

- Dr. Ajeet Jaiswal, Assistant Professor, Pondicherry University, India.

- Dr. Sara Petroccia, Academic Member, ATINER \& Assistant Professor, eCAMPUS University, Italy.

- Dr. Irena Rajchinovska Pandeva, Assistant Professor, Department of Political Science, University Ss. Cyril and Methodius, FYROM.

- Dr. Ilkay Sudas, Assistant Professor, Department of Geography, Ege University, Turkey.

- Dr. Josipa Visic, Assistant Professor, Faculty of Economics, University of Split, Croatia.

- Dr. Jonathan Needham, Associate Teaching Professor, Penn State University-Abington College, USA.

- Dr. Basil A. Akuegwu, Lecturer, Department of Educational Administration and Planning, University of Calabar, Nigeria.

- Dr. Adina Dudau, Academic Member, ATINER \& Lecturer, University of Glasgow, U.K.

- Dr. Susan Stewart, Professor, Western Illinois University, USA.

- Dr. Ibrahim A. Onour, Academic Member, ATINER \& Professor, School of Management Studies, University of Khartoum, Sudan.

- Dr. Dragos C. Mateescu, Lecturer, Faculty of Business, Izmir University of Economics, Turkey.

- Dr. Ercan Kacmaz, Lecturer, Nevsehir Hacı Bektas Veli University, Turkey.

- Dr. Doaa Sayed Abdel Azim, Lecturer of English Literature, October University for Modern Sciences and Arts, Egypt.

- Dr. Eleni Tracada, Academic Member, ATINER \& Lecturer, College of Engineering and Technology, University of Derby, UK.

- Dr. Samodelkin Yakov Aleksandrovich, Lecturer, Urals State of Agrarian University, Russia.

- Dr. Nicholas Rossis, Academic Member, ATINER, Research Associate, Inter Alia \& Institute of International Economic Relations, Greece \& British Ministry of Defence, UK.

- Dr. Zoran Aralica, Senior Research Fellow, The Institute of Economics, University of Zagreb, Croatia.

- Dr. Sofia Gaspar, Postdoctoral Research Fellow, Lisbon University Institute, Portugal.

- Dr. Jonathan Hill, Reader in Postcolonialism and the Maghreb, King's College London, Associate Staff Member, Institute of Middle Eastern Studies, King's College London \& Visiting Fellow, Middle East Centre, London School of Economics and Political Science, U.K. 
- Dr. Monica Sater, Postdoctoral Researcher, Interactive Studio Uppsala, Sweden.

- Dr. Sarmishtha Bhattacharya Dutta, Guest Lecturer, University of Calcutta, India.

- Dr. Tanveer H. Naqvi, Deputy University Librarian \& Adjunct Assistant Professor, Fiji National University, Fiji.

- Dr. Cristóbal Mendoza, Human Geographer, Department of Sociology, Metropolitan Autonomous University (UAM), Mexico.

- Dr. Nimai Chand Saha, Deputy Librarian, Central LibraryVisva-Bharati, India.

- Dr. Joseph Helou, Academic Member, ATINER \& Instructor of Political Science, Lebanese American University, Lebanon.

- Dr. Cristina Lincaru, Academic Member, ATINER \& Researcher, National Scientific Research Institute for Labor and Social Protection-INCSMPS, Romania.

- Dr. Utku Özer, Research Fellow, ATINER.

- Dr. Lamis El Muhtaseb, Post-Doctoral Fellow, School of Advanced International Studies, Johns Hopkins University, USA.

- Dr. Yossef Ben-Meir, President, High Atlas Foundation, Morocco.

- Dr. Mihai Barsan, Assistant Researcher and PhD Candidate, Institute of Political Science and International Relations, University of Bucharest, Romania.

- Ms. Züleyha Sara Belge, Academic Member, ATINER \& Researcher, Centre for Mediterranean Urban Studies, Mersin University, Turkey.

- Mr. Ahmad Abdel-Had, PhD Candidate, Durham University, UK.

- Ms. Zinovia Foka, PhD Candidate, Institute for European Urbanism, Bauhaus University Weimar, Germany.

- Ms. Fairouz Abdullah Megdiche, Architect \& Landscaper, PhD Candidate, ISA Chott-MeriemUniversity of Sousse, Tunisia, \& Lecturer, Design Department, College of Applied sciences- Nizwa, Oman.

- Ms. Sabnam Ghosh, PhD Student \& Teaching Assistant, University of Georgia, USA.

- Dr. Mihai Barsan, Assistant Researcher and PhD Candidate, Institute of Political Science and International Relations, University of Bucharest, Romania.

- Ms Alice Massari, PhD Student in Political Science, European Politics and International Relations, Scuola Superiore Sant'Anna, Italy.

- Ms. Kristina Zábrodská, PhD Student, Institute of Communication Studies, Faculty of Social Sciences, Charles University in Prague, Czech Republic.

- Ms. Sneh Lata Sharma, Senior Manager, TATA Consultancy Services, India.

- Vice President of Publications: Dr Zoe Boutsioli

- General Managing Editor of all ATINER's Publications: Ms. Afrodete Papanikou

- ICT Managing Editor of all ATINER's Publications: Mr. Kostas Spyropoulos

- Managing Editor of this Journal: Ms Fani Balaska (bio)

\section{Reviewers' Board}

Click Here 


\section{President's Message}

All ATINER's publications including the e-journals are open access without any costs (submission, processing, publishing, open access paid by authors, open access paid by readers etc) and are independent of the presentations made at any of the many small events (conferences, symposiums, forums, colloquiums, courses, roundtable discussions) organized by ATINER throughout the year. The intellectual property rights of the submitted papers remain with the author.

Before you submit, please make sure your paper meets some basic academic standards, which include proper English. Some articles will be selected from the numerous papers that have been presented at the various annual international academic conferences organized by the different divisions and units of the Athens Institute for Education and Research.

The plethora of papers presented every year will enable the editorial board of each journal to select the best ones, and in so doing, to produce a quality academic journal. In addition to papers presented, ATINER encourages the independent submission of papers to be evaluated for publication.

The current issue of the Athens Journal of Mediterranean Studies (AJMS) is the fourth issue of the fifth volume (2019). The reader will notice some changes compared with the previous issues, which I hope is an improvement. An effort has been made to include papers which extent to different issues of Mediterranean studies. Two papers are related to history; one to economics and the other to architecture - urban planning.

Gregory T. Papanikos, President

Athens Institute for Education and Research 


\section{Athens Institute for Education and Research A World Association of Academics and Researchers}

\section{3 ${ }^{\text {th }}$ Annual International Conference on Mediterranean Studies 6-9 April 2020, Athens, Greece}

The Center for European \& Mediterranean Affairs organizes the $13^{\text {th }}$ Annual International Conference on Mediterranean Studies, 6-9 April 2020, Athens, Greece sponsored by the Athens Journal of Mediterranean Studies. The aim of the conference is to bring together academics and researchers from all areas of Mediterranean Studies, such as history, arts, archaeology, philosophy, culture, sociology, politics, international relations, economics, business, sports, environment and ecology, etc.You may participate as stream leader, presenter of one paper, chair a session or observer. Please submit a proposal using the form available (https://www.atiner.gr/2020/FORM-MDT.doc).

\section{Academic Members Responsible for the Conference}

- Dr. Yannis Stivachtis, Director, Center for European \& Mediterranean Affairs and Director \& Professor, International Studies Program Virginia Tech - Virginia Polytechnic Institute \& State University, USA.

- $\quad$ Dr. Gregory T. Papanikos, Honorary Professor, University of Stirling, UK.

- Dr. David Philip Wick, Professor of History, Gordon College, USA.

\section{Important Dates}

- Abstract Submission: 9 December 2019

- Acceptance of Abstract: 4 Weeks after Submission

- Submission of Paper: 9 March 2020

\section{Social and Educational Program}

The Social Program Emphasizes the Educational Aspect of the Academic Meetings of Atiner.

- Greek Night Entertainment (This is the official dinner of the conference)

- Athens Sightseeing: Old and New-An Educational Urban Walk

- Social Dinner

- Mycenae Visit

- Exploration of the Aegean Islands

- Delphi Visit

- Ancient Corinth and Cape Sounion

\section{Conference Fees}

Conference fees vary from $400 €$ to $2000 €$ Details can be found at: https://www.atiner.gr/2019fees 


\section{Athens Institute for Education and Research}

A World Association of Academics and Researchers

\section{$18^{\text {th }}$ Annual International Conference on Politics 15-18 June 2020, Athens, Greece}

The Politics \& International Affairs Unit of the ATINER will hold its $\mathbf{1 8}^{\text {th }}$ Annual International Conference on Politics, 15-18 June 2020, Athens, Greece sponsored by the Athens Journal of Social Sciences. The aim of the conference is to bring together academics, researchers and professionals in private and public organizations and governments of Politics and International Affairs and other related disciplines. You may participate as stream leader, presenter of one paper, chair of a session or observer. Please submit a proposal using the form available (https://www.atiner.gr/2020/FORM-POL.doc).

\section{Important Dates}

- Abstract Submission: 11 November 2019

- Acceptance of Abstract: 4 Weeks after Submission

- Submission of Paper: 18 May 2020

\section{Academic Member Responsible for the Conference}

- Dr. Bettina Koch, Head, Politics \& International Affairs Unit, ATINER \& Associate Professor of Political Science, Virginia Polytechnic Institute and State University, USA.

\section{Social and Educational Program}

The Social Program Emphasizes the Educational Aspect of the Academic Meetings of Atiner.

- Greek Night Entertainment (This is the official dinner of the conference)

- Athens Sightseeing: Old and New-An Educational Urban Walk

- Social Dinner

- Mycenae Visit

- Exploration of the Aegean Islands

- Delphi Visit

- Ancient Corinth and Cape Sounion

More information can be found here: https://www.atiner.gr/social-program

\section{Conference Fees}

Conference fees vary from $400 €$ to $2000 €$

Details can be found at: https://www.atiner.gr/2019fees 



\title{
The Contribution of Archaeologists to the Multi-disciplinary Approach in Managerial Studies on Resilience: The Experiences of Sara Santoro ${ }^{1}$
}

\begin{abstract}
By Massimo Bianchi*
The paper wants to discuss the contribution of Archaeology to the multidisciplinary approach in managerial studies on resilience based on the experiences of Sara Santoro, a well-known archaeologist operating in Mediterranean countries and immaturely died. In recent years, the debate on the multidisciplinary approach in managerial sciences expanded due to the technological revolution and multicultural challenges. Another reason of this interest is the increasing attention of scholars to new fields of research and applicative purposes as the management of catastrophes, emergencies and resilience. A particular mention is to be attributed to the scientific and research activities of Sara Santoro, a well-known archaeologist in the Mediterranean area, who recently passed away. Because of the results obtained by this scientist as it concerns the recovering after catastrophic events with a multi-disciplinary approach, the paper aim is to discuss the content of this methodology. The following topics are analysed: the relevance of the survey on the land; the impact of no local staff on the theatre of catastrophic events; the recovering of communities' cultural roots; the role of historical memory in the prevention and management of emergencies, and the management of small teams.
\end{abstract}

Keywords: Archaeology, Multidisciplinary Approach, Interdisciplinary Approach, Resilience Management, Project Management.

\section{Introduction}

This article aims to expose and discuss the contribution of the humanities to the multidisciplinary approach in managerial studies on resilience based on the experiences of Sara Santoro, an illustrious archaeologist operating in Mediterranean countries and immaturely deceased.

Management is a discipline with significant contributions coming from other scientific and technical knowledge. In recent years, the debate on the multidisciplinary approach in managerial sciences expanded due to the technological revolution and multicultural challenges (Tranfield and Starkey 1998). Another reason of this interest is the increasing attention of scholars to new fields of research and applicative purposes as the management of catastrophes, of emergencies and of resilience.

In Archaeology, the debate on the multidisciplinary approach is topical, due in particular to the advancement of ICT-based analytical technologies and tools. The recovery of a community after catastrophic events shows a particular aspect of

\footnotetext{
*Former Full Professor in Management, University of Bologna, Italy.

${ }^{1}$ 1950-2016 Full Professor in Archeology and History of Greek and Roman Art, G.D’Annunzio University of Chieti-Pescara, Italy.
} 
the multidisciplinary approach related to the contribution of the humanistic disciplines, e.g., archaeologists, to the studies on resilience (Koliou et al. 2018).

A distinct mention is attributed to the scientific and research activities of Sara Santoro because of the results obtained by this scientist as it concerns the recovering after catastrophic events with a multi-disciplinary approach. We will examine the multidisciplinary experiences of Sara Santoro on the floor of archaeological excavations and of theoretical assumptions to demonstrate their contribution to the advancement of resilience management. The paper aims to discuss the content of these experiences and its potentials in the advancement of theoretical and applied assumptions on the resilience.

Topics particularly analysed are: 1) the relevance of the survey on the land;2) the impact of no local staff on the theatre of catastrophic events; 3) the recovering of communities' cultural roots; 4) the role of historical memory in the prevention and management of emergencies; 5) the management of small teams.

In these different fields, the multidisciplinary approach means to know how to coordinate different professional skills and specializations, proceeding not by adding or overlapping results that are not completely consistent, but by integrating systematically the contributions that the different methodologies and techniques can produce.

\section{Archaeology and Resilience Management}

Sara Santoro was a classical archaeologist who worked in the period $1980-$ 2016, the year of her immaturely death, in sites mainly located in the Mediterranean area as Pompei (Santoro 2007), Pantelleria (Santoro 2003), Durres (Santoro 2010). Her scientific activity as project manager was also extended to France (the site of Bliesbrook Reiheim) (Santoro and Petit 2007) and to the alpine area at Castelraimondo in Friuli (Santoro 1992, 1995a). Full Professor in Classical Archaeology in the University d'Annunzio of Chieti Pescara, her interests spread on many subjects concerning the Greek and Roman urbanism, the handicraft production, the reception of the image in the ancient art, the methodology of the archaeological research with particular regard to archaeometry and to the recovery of cultural heritage after catastrophic events.

From these activities, it emerges the relationships between archaeology and the resilience management through the pioneering experiences that Santoro developed, in almost forty years of activity for a constant dialogue between the Archaeology and Management, in the relationship between theory and practice of ancient and modern economic activities and in the recovery and enhancement of cultural heritage (Santoro 2017, Thompson Klein 1990). Furthermore she was deepening the relevance of History and Archaeology in the prevention of catastrophic events and in the resilience after disasters. To this purpose, the debates and projects of Sara with the colleagues in managerial sciences of SVIMAP $^{2}$ - an Italian network among researchers on management - created many

\footnotetext{
${ }^{2}$ Network for the development of management in public organizations.
} 
opportunities for comparison, and for the enrichment of knowledge on economic and entrepreneurial activities from an historical perspective (Santoro 1981).

Before I clarify the differences, if they exist, between multidisciplinary and interdisciplinary approach (Knights and Scarbrough 2010). This question, emerged in last decades, was mainly related to education (Alvargonzález 2011, McCulloch 2012) and to management of teams in which different specialists work together to obtain common results. While interdisciplinarity seeks to achieve the synthesis of different disciplines, the multidisciplinary implies collaboration among methodologies and respects specializations without any ambition of integrate approaches. Someone consider not incompatible multi with interdisciplinarity as the interdisciplinarity would be complementary to the existence of multidiscipline regards the management of relationships among disciplines (Ryan and Newman 2010). In the cases we are examining, the methodological perspective it is the multidisciplinary approach that means accepting the usefulness of different disciplines in archaeological studies but not excludes an interdisciplinary management as applied in the resilience management and concretely realized in the work of Santoro (Von Lubitz et al. 2008).

A few decades ago, the resilience was defined, regarding ecological systems, as the ability of a system to return to its equilibrium state after a temporary disturbance (Holling 1973). The term was later considered in engineering, referring to built structures and materials to define the characteristic of recovering the original form after traumatic events. Resilience management defines the ability of a system to resist changes and continue to function. It demonstrates the capability of organizations and communities to endure even intense and sudden changes without permanently undergoing them, but by recovering the previous structures and processes that enable them to function. To this regard the resilience after catastrophic events is located into three main dimensions (Figure 1).

Referring to the arrow of the time in which the event occurred, it is possible to individuate three distinct phases: Prevention, immediate reaction to the emergency and the after catastrophe (Bianchi 2018b, Paganelli 2018). In the prevention, the decision-making horizon is wide as, for example, in earthquakes whose predictability and intensity cannot be foreseen either. This unpredictability makes the measurement of risk uncertain and, consequently, not all prevention activities aimed so much at zeroing the risk but at the reducing the probability of an unfavorable event and the mitigating of its effects. On the other hand, besides protecting cultural assets from damages or destructions, the effects of them can be mitigated through an analytical survey of the sites, buildings, monuments and findings, which allows their recovery, reproduction and, lastly, to retain their memory. 
Figure 1. Main Dimensions of the Resilience Management ${ }^{3}$

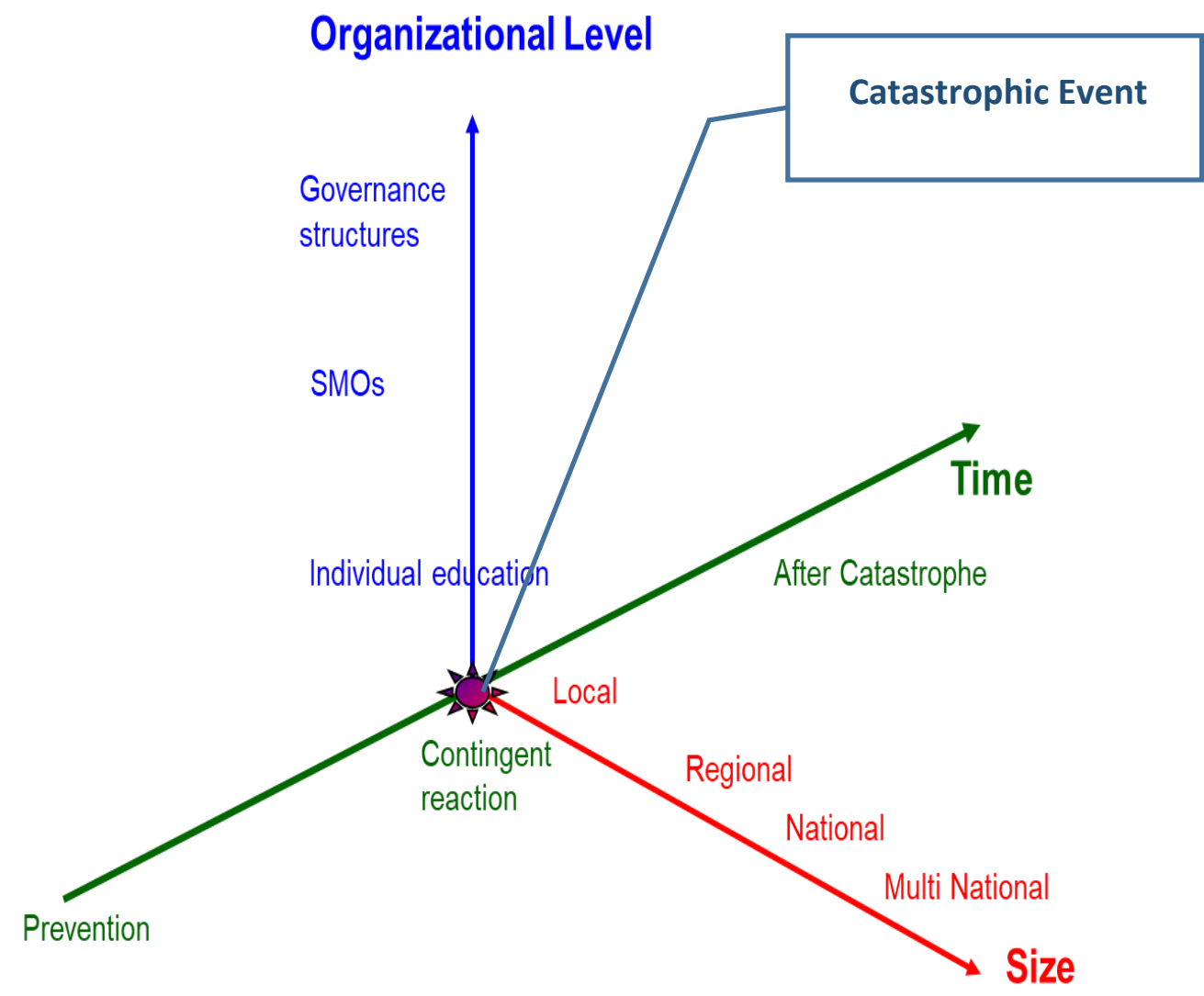

Source: Author.

\section{The Contribute of Sara Santoro to Resilience Management}

Most of the contribute of Sara Santoro to the advancement of Resilience Management originates from her activity for the introduction of new technologies and approaches in Archaeology and in the recovering of cultural heritage.

To this regard is to be mentioned the fight of Sara in favour to the dissemination in Archaeology, of Archeometric disciplines and tools. In 1993 she attracted severe criticisms owing her partnership and support to the constitution of the Italian Association of Archaeometry, which she continued, even later, to give an active contribution. This initiative has allowed her to cultivate the interest in preventive archaeology, the management of emergencies, the restoration, the territorial and urban planning of cultural heritage.

As stated by one of her pupils "She knew how to involve in his research exponents of the most varied disciplines: chemists, physicists, architects, engineers, geologists, restorers etc; she managed with intuition and acumen to keep them all together, through a masterful work of coordination." (Cavalieri et al. 2017).

\footnotetext{
${ }^{3}$ SMOs Small and Medium Organizations.
} 
Sara's multidisciplinary orientation for the use of different tools and disciplines in archaeology has been so decided to suggest "Archeologiae. A plural archeology "as the title of a recent conference dedicated to her memory". Also Barbara Sassi, her close collaborator, mentioned Archeologies referring to Santoro's methodological approach (Sassi 2017).

In parallel, in the eighties, the multidisciplinary of Management received diffused critics, particularly as it concerns the increasing relevance of practitioners and non-academic contributions to the evolvement of managerial studies (AIDEA 1991) and problems concerning the methodological impact of new technologies (Ferraris Franceschi 1990). In these periods, the discussion often misrepresented the true meaning of multidisciplinarity that does not want to create new synthesis or disciplines such as the interdisciplinary approach, but favours the synergistic collaboration among different methodologies and approaches. The undefined boundaries between two approaches was sometime equivocated as authors in resilience management, collecting contributes from different specialists, consider this as an interdisciplinary perspective although it seems really a multidisciplinary one (Kapucu et al. 2013). Just to report about the variety of opinions on the floor, the collaboration inter pares among a variety of specialists realized by Sara in projects like Pompei. Insula del Centenario (Santoro 2007), was defined as a trans disciplinary approach (Coralini 2017). Beyond this terminological question, the application of different disciplines reduces the distances between the theory and the practice of organizations (Ferraris Franceschi 1990) in which different specializations and methodologies coexist to obtain concrete results, in particular in the arena of resilience (Bianchi 2018b).This kind of approach is indicated as essential in the resilience after catastrophic events (Majchrzak et al. 2007, Lucini 2014).

On this subject, almost five main subjects was relating to the activity of Sara in the field of management: 1) the relevance of the survey on the field and of the study of materials; 2) the impact of no local staff on the theatre of catastrophic events; 3) the rebuilding of communities' cultural roots; 4) the role of historical memory in the prevention and in the management of emergencies; 5) the management of small teams.

\section{The Survey on the Field and the Study of Materials}

Sara accepted with difficulty the idea that existed "poor" archaeological sites or of less importance as she was hardly conceives that the solution of problems, considered minor and therefore neglected, could not lead to significant cognitive progresses. It was her belief that apparently scant excavations of materials could produce, through an extensive research, relevant results. As it was recognized "Fascinated by what it represented for her the true connective tissue of the Roman Empire, she was recognized, at national and international level, of the debate on the definition, nature and urbanistic components of the minor settlements and

${ }^{4}$ Archaeologie. A plural story. Studies and Research in Memory of Sara Santoro, Chieti 7-9 Novembre 2017. 
indicators of their economic and social role" (Antonelli et al. 2017). This position was propaedeutic to the assumptions that it is not possible to distinguish surely the very important materials or topics, from the one trivial or insignificant. As she said, during the lessons held in Parma on Methodology and Technique of archaeological research, "the surface survey and the optical examination of the site constitute a different - not a minor - method of investigation, parallel, not only preliminary to the excavation" (Santoro 2005). The same was in the study of the material lying in museums and related deposits. This approach has to be recommended also for the detection of all surrounding elements, traceable to the excavations results.

However, this is also a problem for the Science in which the detection of neglected topics or phenomena can represent an opportunity for significant, if not revolutionary changes, with respect to the knowledge acquired. In the same period, the Management was discussing similar questions. Two majors topics are connected to this perspective: 1) the scarce relevance attributed to Small and Medium Enterprises considered for decades not relevant to understand the functioning of organizations and to offer an effective model for the biggest companies; 2) the scarce interest with which the concrete relationships with customers and suppliers was studied for the structuring of network organizations and, more generally, in the orientation of the managerial science (Bianchi and Tampieri 2013, Diaz et al. 2010 ).

Another significant aspect is given by the direct study of materials. As pointed out by one of her pupils (Guiducci 2018), Sara contributed with the collaboration of the Faenza CNR to the first Italian workshop on the archaeometric analyses of raw ceramics, which was followed by important contributions on the subject (Santoro 1993, Santoro and Fabbri 1998, Santoro and Guiducci 2001). In this occasion, Sara expressed her disconcert in realizing that some authors who also theorized models of interpretation or commented on the results of archaeological research, did not have a direct knowledge of these materials, nor had they analyzed them in depth with all available technologies. Often they have not touched, manipulated, analyzed in person but have spoken about it on the basis of other sources, in turn indirect. Her conviction was, as a militant archaeologist, that the study of direct materials carried out on site and in the immediate vicinity of their discovery, was fundamental for the knowledge of historical facts and in the prevention of catastrophes also made by human beings (Santoro 2016).

In last periods, the introduction in Management of Intelligent Systems testified the increasing relevance of facts, material facts, in the study of organizations and their dynamics (Bianchi et al. 2012) once indicated as the essential elements to individuate organizational boundaries in a dynamic environment (Bianchi 2004). The lack of empirical studies concerning the dynamic capability approach, recently observed, confirms that the direct study of material events is a limit also in managerial studies (Della Corte and Del Gaudio 2013) and in the analysis of business relationships (Srinivasan et al 2011). One reason of this can be attributed to the diffusion of non-standard organization of small business, to the multidisciplinary model of their action and to the difficulty, also for a multidiscipline as the management, in applying a multidisciplinary approach. 


\section{The Impact of No Local Staff on the Theatre of Catastrophic Events}

The intervention of recovering the cultural heritage after catastrophic events can clash, not only with disagreements about its implementation and the methods to be followed, but also with the opposition of not transparent interests aimed to the maintaining of the status quo or to creating competing solutions. This experience was dramatically clear to Sara during the excavations of Castelraimondo whose difficulties are clearly evoked by Ghedini in her essay on the activities of Sara in Castelraimondo (Ghedini 2018), and after replied in Pompei (Bianchi 2018a).

The successive step of Archaeological Park creation, after the excavations and the materials recovering (Santoro 1991, 1995a), was not free from this risk. What the events of other parks seem to teach, is that relations with the local system are not only relevant from the point of view of acceptance and support of the initiative. This concerns also the prevention or at least the mitigation of damage, sabotage or vandalism that may result, not only from interests opposed to the creation of a park, but also from a negative attitude towards what can be interpreted by the local culture as a foreign body (Leila 2015).

Preventing and/or mitigating these reactions is a problem that the agenda of activities consequent to the impact of the staff foreign to the local culture and interests must take into account. It is not by chance that, in the organizational field, the problem is tackled considering each project or innovative initiative in the field of resilience as an arena in which different ideas and subjects of conflicting interests and methodologies collide, capable of producing negative and extreme consequences (Bianchi 2018b).

\section{The Rebuilding of Communities' Cultural Roots}

In Castelraimondo the challenge was represented by the involvement of the local community, decimated by the earthquake occurred few years before. The way to reach this objective was the recovery of its historical roots and in being aware of the work that was taking place on the site by the teams of archaeologists and until then theatre of legends and illegal excavations.

Furthermore, the site was covered by luxuriant and invasive vegetation in which the holes produced by the senseless diggers of the "tombaroli" stand out like open wounds in the ground and in the historical memory.

After the successful excavations, the ambitious project conducted by the scholar was aimed at creating an area equipped for the public, in which archeology was not the only attraction, but dialogued with the suggestive surrounding environment (Ghedini 2018).

An integral part of this project was the creation of an exhibition and a series of popular texts with the assumption of a series of well-chosen communicative choices implemented by drawing on different disciplines and techniques.

Among these are to be mentioned: the creation of an identity logo, the type of panels, the elaboration of the routes, the creation of rest areas and especially the restorations and consolidations carried out in the open air. It should be 
remembered that more than twenty years after its construction and apart from ordinary maintenance, the park remained in perfect working order up until the present day. All this has a name: sustainability and environmental sustainability, a concept to which various disciplines contribute that Sara was able to manage successfully (Ghedini 2018).

Figure 2. Detail of the Durazzo Amphitheater

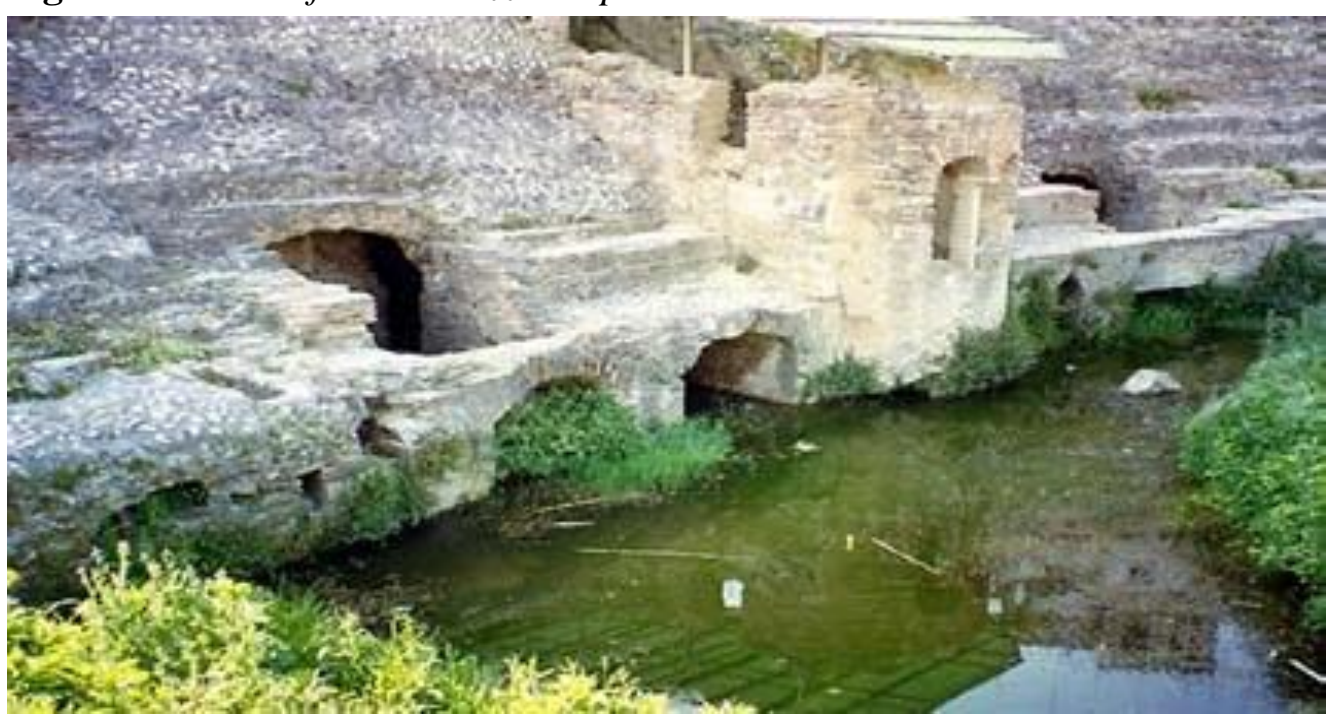

Source: Author (2017).

In Durres there was not only to recover an imperial monument that became an open sewer (Figure 2). The objective was to rebuild the culture of a country seriously damaged by years of disorder during which many sites and museums was stripped of materials very precious for the Albanian history and culture while a wild building cemented areas of great historical value (Hoti 2018). It is not a coincidence that a section of the exhibition organized by Sara in Durres, was dedicated to these havoc and to the project, then realized in the following years, the map of the archaeological risk of Durres (Figure 3) connected to the new urban plan of the city unfortunately till today widely disregarded (Santoro 2003).

In this map were published the results of a project, coordinated by Santoro, with Archaeologists, Historians, Architects, Engineers, Archeometrists, Surveyors together with Public and Private Managers supported by their staffs (Santoro et al. 2010). Once again, Santoro's contribution to the dissemination of new technologies on the archaeological ground in terms of resilience of cultural heritage was crucial and consciously implemented (Buora and Santoro 2004).

\section{The Historical Memory in the Prevention and in the Management of Emergencies}

An additional information inserted in the Risk Map of Durres concerns the studies of catastrophic events occurred in the area in past time. The synthesis 
realized by Sara in the Durres Risk Map allows to glimpse two distinct dimensions of multidisciplinarity, one that extends within the historical and humanistic sciences and another that involves disciplines and approaches external to history but relevant to the study of data and materials from a biological, economic perspective. The first teacher of Sara, Guido Achille Mansuelli (1970), led her on the road to urban planning in ancient cities, while Andrea Carandini's studies on the methodology of the archeological excavation (Carandini 1981), were for her themes of reflection and concrete application. Among the sources of interdisciplinarity, in Sara, it is to remember her friendship with Raymond Chevallier, a forerunner of the use of topography and aerial photography in Gallia Cisalpina and of studies on the road network of antiquity (Chevallier 1972).

Numerous was her contributes to archaeosismology (Santoro 1995b, Guidoboni and Santoro 1995, 1996) and their use to prevent catastrophic events as an early phase of resilience. It is to be mentioned the participation of Sara to the preparation of the RESINT Project ${ }^{5}$ in which she gave the contribute concerning her experience in Practice Management (Simulimpresa) for the start-up of innovative companies in the cultural tourism sector as an opportunity to recover the memory and awareness of cultural heritage after disasters (Santoro 2013).

The didactical model of Practice Firm goes through the reproduction of business functions and departments allowing students to acquire skills and knowledge (Gualdi and Melagranati 2015) about a firm working according to learning by doing principle (DuFour et al. 2010).

In practice management, these experience followed her intervention in the planning and teaching of the Training Courses held in 2009 in Elbasan (Cultural Tourism Business Sector) within the project "Start of vocational training with particular regard to the weak categories", in her Simulimpresa teaching, at the Novosibirsk Technical University, and finally at the CEUB - University Residential Center of Bertinoro of the University of Bologna (RESINT Project). In this direction, within the CHTMBAL Tempus Project ${ }^{6}$, directed by Santoro, was created two masters in cultural heritage for professional purposes (University L. Gurakuqi of Shkoder) and for public managers of superintendence of cultural heritage (University of Prizren).

\footnotetext{
${ }^{5}$ Reformation of Curricula on Resilience Management with Intelligent System in Open Source and Augmented Reality. Knowledge Alliance Project, 2014-2016

${ }^{6}$ Network for Cultural Heritage and Tourism Management Curricula in Balkan Universities. Tempus Project, 2011-2015.
} 
Figure 3. The Degrees of Territorial Protection Adopted in the New 2007 PRG of Durres on the Basis of the Archaeological Risk Map

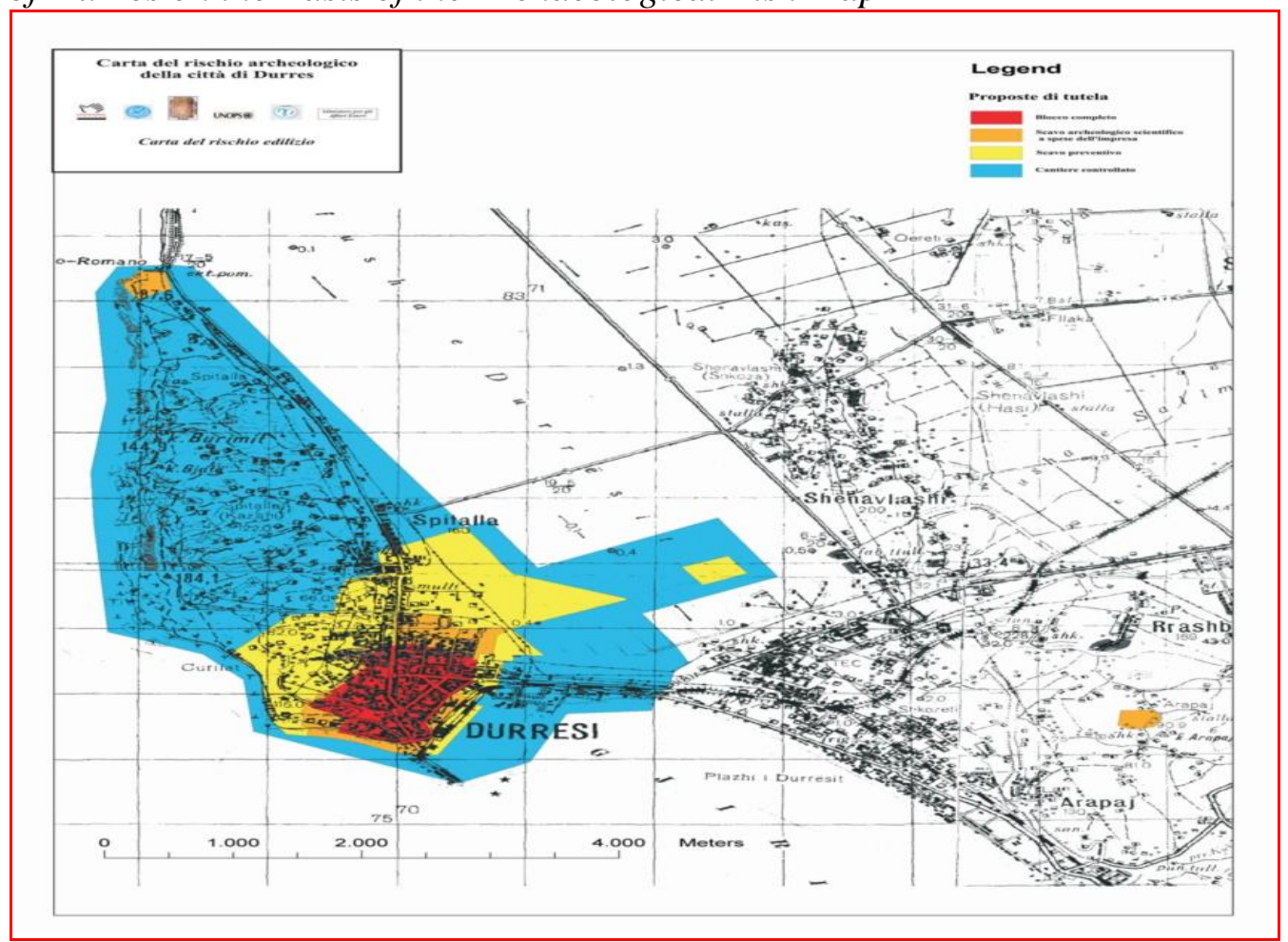

Source: Rovigatti (2007).

This lead directly to the contribution of Sara to empirical studies on the management of small teams which was conducted by the Laboratory of Simulimpresa of the Bologna University during the above mentioned projects (Bianchi and Tampieri 2015).

\section{The Management of Small Teams}

The militant archaeology that distinguished Sara, led her to underline, in the Frédérick manual that accompanied the years of her scientific training (Frédéric 1970), the phrase "the archaeologist is not a solitary worker but needs a myriad of people who they provide information and specialized technicians, both for research and for the study of the land, the analyses and the final documentation" (Frédéric 1970). Confirming the multidisciplinary orientation, the management of small groups directed by our archaeologist, implied the leadership of teams coming from different countries, disciplines and level of studies and normally characterized by a small dimension. At the other side, this experience enforced her vision concerning the role, in economic systems and in cultural events, of small enterprises. It is not by chance that the management of cultural tourism and the role played by small and medium-sized enterprises was the theme of the first Sara's Conference in Tirana, on 2 July 2002, "Cultural enterprise: an opportunity for the development and promotion of Albania. Perspectives and 
initiatives in progress for the training and support of entrepreneurs and cultural operators". This title was a real methodological and programmatic declaration of what she would have done later in the Land of Eagles and in the subsequent initiatives carried out in other areas, not only Balkans and of Central Asia.

A trace of the attention given to managerial problems of organizational units, can be found, on the excavations of the Insula del Centenario of which Sara was Scientific Responsible, in the organizational map of positions involved in the initiative, prepared by Sara and discussed with participants to find the most appropriate solution (Figure 4).

In the Management theory, the position of small and micro enterprises is still quite neglected, compared to the richness of knowledge that someone attributed to this business dimension (Bianchi et al. 2008).

Meanwhile, after so many long and diffused negative experiences in the development of transition countries, many Authors, engaged in this field, clearly declared the inadequacy of tools until now employed to this purpose (Carothers 2002, Thomas 2008, Ballow 2005).

To this regard, as Project Manager, Sara was aware that the development of local systems in transition countries, through the recovering of cultural heritage and related tourism, represented a challenge for project management particularly concerning the short-term sustainability of the project itself and the appropriateness of results to middle and long-term expectations.

The variety of decisional framework that the project manager in cultural tourism sector has to consider includes: 1) the relevance of destination management, to focus the tourism demand on the destinations and on potential entrepreneurial and business perspectives; 2) the changing strategy of the commitment in which the local stakeholders increase their initiatives for the development of local system based on tourism and an extended version of tourism focused on cultural heritage.

To this regard the multidisciplinarity of Sara met the demand of a cross cultural approach (McMurray and Karim 2008) concerning the way to apply western methodologies in different contexts. In Historical and Archaeological field, this subject touches a very attentive sensitivity to the historical location of events like she did in the promotion of the Mosella Park in Bliesbrook Reinheim with the exposition Vivre en Europe Romaine: De Pompei à Bliesbruck-Reinheim (Santoro and Petit 2007). In this experience was applied the methodology of network organization with multiple small teams, strongly committed, which collaborate autonomously with a management by objectives. 
Figure 4. Organizational Map of the Project Insula del Centenario, Pompei 2004

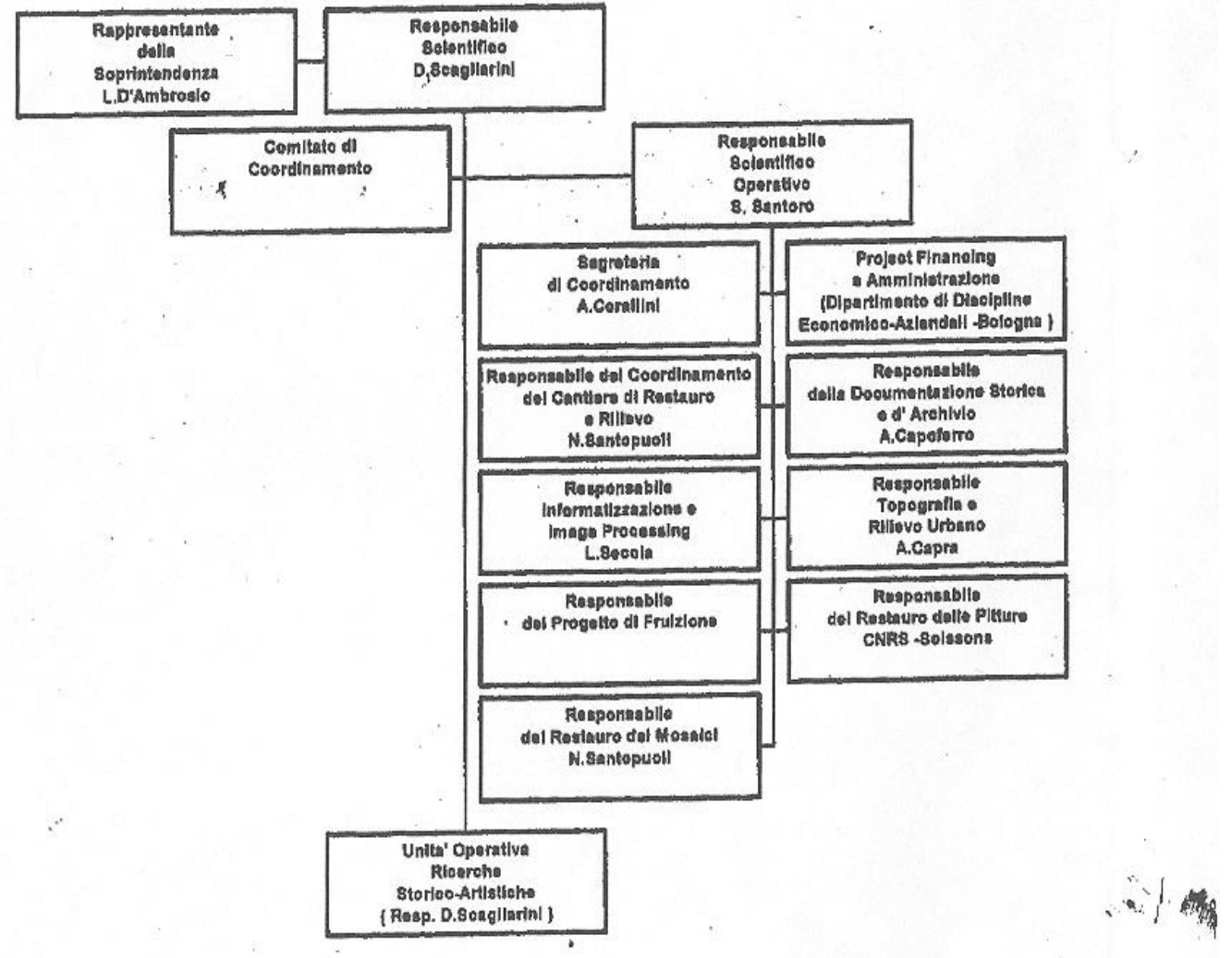

Source: Original notes of Sara Santoro.

\section{Conclusions}

The multidisciplinary approach applied by Sara was not limited to the scientific and popular aspect. In 2012 she participated in the D'Annunzio University of Chieti Pescara, where she held the last period of his career, to the establishment of the DISPUTER, Department of Psychological, Humanities and Territory Sciences ${ }^{7}$. In the following years, she concurred to the consolidation of this experience with conviction and enthusiasm, fascinated as she was from the challenge of collaborating with colleagues working in apparently unrelated sectors. This Multidisciplinarity was particularly appreciated at international level in the positive evaluation of numerous projects in which the multidisciplinary approach was a distinctive quality of the submissions.

The path we are examining was not free from oppositions and dissensions. There are two main orientations of these criticisms. On the one hand, multidisciplinarity can be criticized as a dispersive process and, on the other hand, because in Sara it was focused on doing cultural enterprise, being rejected as a dangerous product of corporatism.

The cultural enterprise was a central subject in the activities of Sara. She believed that the excavations and the next recovering of the cultural heritage

\footnotetext{
${ }^{7}$ Today Department of Psychological, Health and Territory Sciences.
} 
was not only an opportunity to collect useful materials and data for the academic community or for a small group of scholars but also, on the part of local communities, a chance to rediscover their identity and to trig of a new social and economic development after crisis and disasters.

To this purpose, the multidisciplinarity implies the intervention of different competencies and specialities but, fundamentally, the capability to coordinate various professionals and local exigencies.

Those who criticize multidisciplinary observe that, by combining different approaches, in the end they do not deepen any of them, they compromise and lead to the loss of the scientific rigor of a pure method, leading to little meaningful results.

It is also true, however, that the problem is rather that of managing in progress the process of knowledge and continuously improving it. When the barriers between disciplines and specializations become an obstacle, we must not hesitate to bring them down or at least to question them.

The mutual contamination of the archaeology with management, it is claimed, focuses the attention of the scholars on utilitarian and functional objective. In this way, the activity of the archaeologist is distracting or removing from the mission of studying the civilizations and human cultures of the past with the collection, documentation and the analysis of the material traces they have left. Yet the identification of sites, the organization of excavations, the analysis of materials, their interpretation, publication and dissemination of results together with the enhancement of places, should lead the archaeologist to be an "entrepreneur" in the true sense of the word. This means applying the concept of cultural enterprise with its innovative and militant charge as well as Sara did.

Less problems were encountered in management owing its multidisciplinary or interdisciplinary attitude.

Without any doubt, for archaeologists this is a revolutionary point of view as it combines the multidisciplinary with the entrepreneurship and the culture, three topics on which discussions and conflicts are renewed. Moreover, this combination leads to a strong orientation towards innovation that would seem risky for many, creating a worrying attitude, in a discipline considered so classic and fundamentally traditionalist as Archeology.

As Barbanera wrote, "it would be good that in Italian archeology we could reach a middle ground between the drive towards radical renewal and the tendency of the academic structures to reproduce themselves" (Barbanera 1998). Surely, Sara, in her positivism, was inclined towards a profound renewal, which, more than with corporatism, is combined with her entrepreneurial attitude and with the cultural enterprise in particular. Consequently, the limits with the other disciplines, fundamental for the methodological study of techniques and approaches, did not constitute for Sara an obstacle for the progress of knowledge.

In this, she perfectly agreed with Carandini when he observed "The formation of specialized disciplines ...... has therefore no cultural foundation in itself" (Carandini 2000). This last contribution of Sara to the resilience management will be a further reason for reflection for the proliferation of specializations not always 
motivated by the methodological originality and the specificity of the field of study and intervention.

\section{References}

AIDEA (1991) Continuità e rinnovamento negli studi economico-aziendali [Continuity and renewal in economic - business studies]. In Proceedings of the $13^{\text {th }}$ Convention of AIDEA, Pisa 11-12 oct. 1990, Bologna: Clueb.

Alvargonzález D (2011) Multidisciplinarity, interdisciplinarity, transdisciplinarity, and the sciences. International Studies in the Philosophy of Science 25(4): 387-403. DOI: 10.1080/02698595. 2011.623366.

Antonelli S, Bolzoni, G, Dazzi A, Moderato M, Andreetti E (2017) Premessa [Introduction]. In S Santoro (ed) Emptor e Mercator Spazi e rappresentazioni del commercio romano [Emptor and Mercator. Spaces and representations of Roman trade]. Bari: Edipuglia.

Ballow DG (2005) Globalization and Cross - Cultural Issues in Project Management. McKinney: Project Management Knowledge Transfer, Inc.

Barbanera M (1998) L'archeologia degli italiani, [The archaeology of Italians], 191. Roma: Editori Riuniti.

Buora M, Santoro S (2004) Progetto Durrës. Atti del secondo e del Terzo incontro scientifico. Strumenti della salvaguardia del patrimonio culturale. Carta del rischio archeologico e catalogazione informatizzata. Esempi italiani ed applicabilità in Albania. [Progetto Durrës. Proceedings of the second and third scientific meeting. Tools for the safeguarding of cultural heritage. Archaeological risk map and computerized cataloging. Italian examples and applicability in Albania], Villa Manin di Passariano, Udine-Parma 27 ${ }^{\text {th }}-29^{\text {th }}$ March 2003; Alte Tecnologie applicate all'archeologia di Durrës [High technologies applied to the archaeology of Durrës], Durres $22^{\text {th }}$ June

Bianchi M (2004) Trust impact in the renewal of Management Systems: Theoretical problems and empirical evidences for boundary maintaining. Economic Research, Facultet Ekonomije I Turizma, Pula, Slovenia 17(2): 63-82.

Bianchi M (2018a) Il concetto di parco archeologico secondo Sara. Atti del Convegno Archeologie. Una storia plurale, Studi e ricerche in memoria di Sara Santoro [The concept of archaeological park according to Sara, Proceedings of the Conference Archaeologiae. A plural story, Studies and research in memory of Sara Santoro], University D'Annunzio of Chieti-Pescara, Chieti 7-9 November 2017). Forthcoming.

Bianchi M (2018b) The arena of resilience in catastrophic events. Extended Abstract WOA 2018 Meeting. ASSIOA 2018 Conference on The Resilient Organization: Design, Change and Innovation in the Globalized Economy. Papers Track: Organization. n. 22. Rome, Italy, $15^{\text {th }}-16^{\text {th }}$ February.

Bianchi M, Tampieri L, Tesic J, Imoniana JO (2008) Comparing the role of managerial control in micro family business start-up in Bosnia Erezegovina, Brazil and Italy. Corporate Ownership and Control 7(2)-Winter. ISSN 1727_9232, 224-237.

Bianchi M, Kaklauskas A, Imoniana JO, Levy Orelli R, Tampieri L (2012) The evaluation of Network Performance in Cultural Heritage Through Intelligent Systems. In M De Marco, D Te'eni, V Albano, S Za (eds) Information Systems: Crossroads for Organizations, Management, Accounting and Engineering, 387-395. Springer. 
Bianchi M, Tampieri L (2013) Effects of Networking Activities by Internet on the Creation of a Business Network; Experimental Results of Simulimpresa Laboratory. In P Spagnoletti (ed) Organizational Change and Information Systems, 119-127. Springer.

Bianchi M, Tampieri L (2015) The networking in the start-up of SMEs for the development of local system. The role of Tourism Enterprises. In S Santoro (ed) Skills and Tools to the Cultural Heritage and Cultural Tourism Management II Vol. ISBN 978-88-97017-08-0.

Carandini A (1981) Storie dalla terra. Manuale dello scavo archeologico [Stories from the earth. Handbook of the archaeological excavation], Bari, De Donato Cavalieri M, Boschetti C, Mastrobattista, E. (2017) Introduzione [Introduction], in Cavalieri, M. and Boschetti, C. Eds. Il polisemico significato della moderna ricerca archeologica. Multa per Aequora. [The polysemic meaning of the modern archaeological research], Presses Universitaires de Louvain, V.1, 604.

Carandini A (2000) Giornale di Scavo. [Excavation Journal], 188. Torino: Einaudi.

Chevallier R (1972) La photografie aérienne [The aerial photography]. Étude Rurales, No. 48.

Coralini A (2017) Archeologie Alibi: Metodi e Strumenti, Il Caso dell'Insula IX [Alibi Archeology: Methods and Tools, The Insula Case IX. 8], In A Coralini (ed) Pompei IC 8, Vecchi e Nuovi scavi [Pompei IC 8 Old and new excavations] (1879-), Ante Quem, Department of History, Culture and Civilization. Bologna: Bologna New Series.

Carothers T (2002) The End of the transition paradigm. Journal of Democracy Johns Hopkins University Press. 13:1(January).

Della Corte, V., Del Gaudio, G. (2013) Exploring the Co-Evolution of Dynamic Capabilities: From the firm to the Network or vice versa. In P Adinolfi, R Cafferrata, A Tommasetti Management senza confini [The Management without borders], 5158. Bologna: Il Mulino.

Diaz P, Acuna P, Aedo I, Malizia A (2010) A design patterns Catalog for Web-Based Emergency Management Systems. In A D'Atri, A De Marco, AM Braccini, F Cabiddu (eds) Management of the Interconnected World, 387-394. Springer.

DuFour R, DuFour R, Eaker R, Many T (2010) Learning by Doing: A Handbook for Professional Learning Communities at Work TM. Solution, Tree Press, Bloomington, Indiana, 2013.

Ferraris Franceschi R (1990) Informatica e ricerca in Economia Aziendale [Informatics and research in Business Economics]. In R Varaldo (ed) Informatica ed Economia Aziendale [Business Economics and Informatics], 21-47. Bologna: CLUEB.

Frédéric L (1970) Manuale pratico di archeologia [Practical handbook of Archaeology]. Milano: Mursia.

Ghedini F (2018) Valorizzazione e comunicazione nell'attività di Sara Santoro. [Valorization and communication in the activity of Sara Santoro]. In M Cavalieri, C Boschetti (eds) Multa per Aequora. Il polisemico significato della moderna ricerca archeologica [Multa per Aequora. The polysemic meaning of the modern archaeological research]. Presses Universitaires de Louvain, 1, 38.

Gualdi D, Melagranati F (2015) Metodologie innovative nell'accounting education. La simulazione d'impresa. Indagine sulle motivazioni e aspettative degli studenti universitari di Forlì e Parma, Quaderni DEM [Innovative methodologies in accounting education. Business simulation. Survey on the motivations and expectations of the university students of Forli and Parma. Notebooks DEM], 4, 125. 
Guidoboni E, Santoro S (1995) Collapses and seismic collapses in archaeology: proposal for a thematic atlas. Annali di Geofisica XXXVIII (5-6): 1013-1018.

Guidoboni E, Santoro S (1996) Dalla sismologia storica all'archeosismologia [From historical sismology to Archaeosismology], Ocnus No 4.

Guiducci G (2018) Da Castelraimondo al Mediterraneo: ventidue anni di Archeo-metria della ceramica grezza. [From Castelraimondo to the Mediterranean: twenty- two years of archaeometry of raw ceramics]. In M Cavalieri, C Boschetti (eds) Multa per Aequora. Il polisemico significato della moderna ricerca Archeologica [Multa per Aequora. The polysemic meaning of the modern archaeological research], 1, 45-50. Presses Universitaires de Louvain.

Holling CS (1973) Resilience and stability of ecological systems. Annual Review of Ecology and Systematics 4: 1-23.

Hoti A (2018) Il contributo di Sara Santoro allo sviluppo delle ricerche Archeo-logiche a Durazzo [Sara Santoro's contribution to the development of Archaeo- logical research in Durres]. In M Cavalieri, C Boschetti (eds) Multa per Aequora. Il polisemico significato della moderna ricerca Archeologica [Multa per Aequora. The polysemic meaning of modern archaeological research], Presses Universitaires de Louvain, 1, 38 .

Kapucu N, Hawkins CV, Rivera FI (2013) Disaster Resiliency. Interdisciplinary Perspectives. London: Routledge.

Koliou M, Van de Lindt JW, McAllister TP, Ellingwood BR, Maria Dillard M, Cutler H (2018) State of the research in community resilience: progress and challenges. Sustainable and Resilient, Infrastructure Journal, Taylor and Francis on line, Available at: https://doi.org/10.1080/23789689. 2017.1418547.

Knights D, Scarbrough H (2010) In Search of relevance: perspectives on the contribution of academic - practitioner networks. Organization Studies 31(9-10): 1287-1309.

Leila A (2015) Cultural heritage vandalism and looting: the role of terrorist organizations, public institutions and private collectors. Santander Art and Culture Law Review 2: 27-62.

Lucini B (2014) Multicultural approaches to disaster and cultural resilience. How to consider them to improve disaster management and prevention: the italian case of two earthquakes. Procedia Economics and Finance, Elsevier 18: 151-156.

Majchrzak A, Jarvenpaa SL, Hollingshead AB (2007) Coordinating Expertise Among Emergent Groups Responding to Disasters. Organization Science, Published Online: February 1, 147-161.

Mansuelli GA (1970) Architettura e città. Problemi del mondo classico [Architecture and the city. Problems of the classical world]. Bologna: Edizioni Alfa [Alfa Publishing].

McCulloch G (2012) Introduction: Disciplinarity, Interdisciplinarity and Educational Studies - Past, Present and Future. British Journal of Educational Studies 60(4): 295-300. DOI: 10.1080/00071005.2012.744185.

McMurray AJ, Karim A (2008) A perspective on multiculturalism and policing. Cross Cultural Management: An International Journal 15: 4. UK: Emerald.

Paganelli G (2018) Dimensioni organizzative e prospettive del resilience nei lavori di Sara Santoro Atti del Convegno Archaeologie. Una storia plurale, Studi e ricerche in memoria di Sara Santoro [Organizational dimensions and resilience perspectives in the works of Sara Santoro. Proceedings of the Archaeologie Conference. A plural story, Studies and Researches in memory of Sara Santoro]. University D'Annunzio of Chieti-Pescara, Chieti 7-9 November 2017 (Forthcoming).

Ryan S, Newman R (2010) The Rise and Fall of Interdisciplinarity in Management Education, Australian and New Zeeland Academy of Management, $24^{\text {th }}$ ANZAM Conference. 
Rovigatti P (2007) Piano urbanistico integrato della città vecchia di Durazzo [Integrated urban plan of the old city of Durres], Durazzo.

Santoro S (1991) L'indagine archeologica nei siti fortificati del Friuli romano: il caso di Castelraimondo, in Castelli e citta' fortificate. Storia, recupero, valorizzazione", [The archaeological survey in the fortified sites of Roman Friuli: the case of Castelraimondo, in Castles and fortified cities. History, recovery, valorisation"] Atti del Convegno Internazionale di Palmanova 1989, [Proceedings of the International Conference of Palmanova 1989], Universita' di Udine.

Santoro S (1981) I segni dell'organizzazione nelle culture preindustriali, in Bianchi, M.(ed) "Prospettive di Organizzazione Aziendale" Numero speciale, IN.AR.COS - Ingegneri, Architetti e Costruttori [The signs of organization in pre-industrial cultures. In M Bianchi (ed) "Perspectives of Business Organization" Special issue, IN.AR.COS, - Engineers, Architects and Builders] Anno XXXVI,423, Bologna, 41015.

Santoro S (1992) Castelraimondo. Scavi 1988-1990. I. Lo scavo, Cataloghi e Monografie dei Musei Civici di Udine [Castelraimondo. Excavations 1988-1990 I. Computer science, archaeometry and study of materials, Catalogs and Monographs of the Civic Museums of Udine] 2. Roma: Erma di Bretschneider.

Santoro S (1993) Archeometria della ceramica. Problemi di metodo. Atti della giornata di studi [Proceedings of the study day], 8o SIMCER, 12.11.1992 Rimini, Ceramica Acta, Bologna.

Santoro S (1995a) Castelraimondo. Scavi 1988-1990 II. Informatica, archeometria e studio dei materiali, Cataloghi e Monografie dei Musei Civici di Udine, Cataloghi e Monografie dei Musei Civici di Udine [Castelraimondo. Excavations 1988-1990 II. Computer science, archaeometry and study of materials, Catalogs and Monographs of the Civic Museums of Udine], Roma: L' Erma di Bretschneider, 528.

Santoro S (1995b) Ambiguous evidence: earthquakes and ancient building techniques in an alpine example 4th-7th centuries. Annali di Geofisica XXXVIII(5-6): 753- 762.

Santoro S (2003) Ceramics and society in Late Antiquity: Pantellerian Ware, a case history. In S Di Pierro, V Serneels, M Maggetti (eds) Fribourg, Ceramics in the Society. Proceedings of the $6^{\text {th }}$ European Meeting on Ancient Ceramics (EMAC), Fribourg, Switzerland, 3-6 October 2001.

Santoro S (2005) Metodologia e Tecnica della Ricerca Archeologica [Methodology and Technique of Archaeological Research], University of Parma Official Handouts of the Course on the Methodology of Archaeological Research.

Santoro S (2007) Pompei. Insula del centenario (IX, 8). Vol. 1: Indagini Diagnostiche geofisiche e analisi archeometriche.[Pompei. Insula of the Centenary (IX, 8). Vol. 1: Geophysical diagnostic investigations and archaeometric analysis].Ante Quem, Department of Archaeology, Bologna University, now Department of History, Cultures and Civilization. Bologna New Series.

Santoro S (2010) Roman Amphitheatres and Cultural Basins: the Durres case (Albania) in M Bianchi, L Del Bene, L Tampieri, S Zarich (eds) Territorial basins and cultural basins in the development of small and medium-sized enterprises, 229-230. Cesena: Ed. Il Pontevecchio.

Santoro S (2013) Skills and tools to the Cultural Heritage and Cultural Tourism Management. Teramo: Edizioni D'Errico.

Santoro S (2016) Archeologia, isendità e Guerra [Archaeology, identity and war]. Bologna: Il Mulino No 4, 705-714.

Santoro S (2017) Emptor e Mercator. Spazi e rappresentazioni del commercio romano Emptor and Mercator. [Spaces and representations of Roman trade],Bari; Edipuglia. 
Santoro S, Fabbri B (1998) Il contributo della analisi archeometriche allo studio delle ceramiche grezze e comuni di età romana. Il rapporto forma/ funzione/impasto, Atti della $1^{a}$ giornata di archeometria della ceramica. [The contribution of archaeometric analysis to the study of rough and common ceramics of the Roman age. The relation form/function/mixture, Proceedings of the 1st day of archaeometry of ceramics], Bologna 28.2.1997.

Santoro S, Guiducci G (2001) Pantellerian Ware a Pantelleria: il problema morfologico [Pantellerian Ware in Pantelleria: the morphologic problem]. RCRF Acta Lugdunensis Conventum 37(Abindgon): 171-175.

Santoro S, Petit JP (2007) Vivre en Europe Romaine: De Pompei à Bliesbruck -Reinheim. [Living in Roman Europe: From Pompei to Bliesbruck-Reinheim]. Paris: Errance.

Santoro, S., Sassi, B. and Hoti, A. (2010) Una nuova immagine dell'urbanistica diEpidamnos Dyrrachium dagli scavi e dalle ricerche del Dipartimento di Archeologia e della Missione Archeologica Italiana a Durres, Illyria del Sud ed Epiro nell'antichità "L'Illyrie Méridionale et l'Epire dans l'Antiquité", V, Actes du V Colloque international de Grenoble. [A new image of the urban planning of Epidamnos Dyrrachium from Excavations and researches by the Department of Archeologia and the Italian Archaeological Mission in Durres in the Southern Illyria and Epirus in Antiquity"]. In JL Lamboley, MP Castiglione (eds) Proceedings of the V International Symposium in Grenoble] (10-12 October 2008), De Boccard, Paris, vol. I, 299- 324.

Sassi B (2017) Dyrrachium III. Storia e archeologia di una città portuale tra Oriente e Occidente, Biblioteca Archeologica [Dyrrachium III. History and archeology of a port city between East and West,Archaeological Library] $\mathrm{N}^{\mathrm{o}}$ 41, Bari: Edipuglia, 10.

Srinivasan M, Debmalya M Ajai G (2011) Buyer - Supplier Partnership Quality and Supply Chain Performance: Moderating Role of Risks, and Environmental Uncertainty, European Management Journal, $\mathrm{N}^{\mathrm{o}} 25$.

Thomas DC (2008) Cross-cultural management. London: SAGE.

Thompson Klein J (1990) Interdisciplinarity, History, Theory and Practice, 56-75. Detroit: Wayne State University Press.

Tranfield D, Starkey K (1998) The nature, social organization and promotion of management research: towards policy. British Journal of Management 9(4): 341353.

Von Lubitz DK, Beakley JE, Patricelli F (2008) All hazards approach' to disaster management: the role of information and knowledge management, Boyd's OODA Loop, and network centricity. Disaster 32(4): 561-585. 


\title{
Israel and the Arab World - Renewal of the Alliance of the Periphery
}

\author{
By Eyal Zisser*
}

During the seventy years of its existence, Israel's relations with the Arab world have experienced a radical turnabout. What began as deadly hostility to the existence of the Jewish state passed over into resignation and a willingness to coexist, even if this was the result of having no choice. Recently, a new stage evolved, with some Arab states willing to develop ties of cooperation that point in the direction of a strategic security alliance. In the 1950s, Israel's partners to the "Alliance of the Periphery," were the non-Arab states on the periphery of the Middle East, which had to confront the rising Arab nationalism of the time and its undisputed leader, Gamal Abd el-Nasser. Sixty years later, the periphery states, or at least Iran, and to some extent, Turkey, have become influential players in the regional arena, in such a way as to represent a challenge to Israel and many of its neighboring Arab states. Israel came into existence finding itself in a prolonged and apparently insoluble conflict with the Arab states, but now, some of the latter have become Israel's partners in face of the Iranian threat and the Turkish challenge. The present "alliance" reflects the changing face of the Middle East and the deep processes it is undergoing. At the head of these is the decline of Arabism and the decline of the Arab world, while on the other side, Iran and Turkey, and Israel too, are rising in influence and power. Indeed, it is these three countries that today dictate the path the Middle East will take.

Keywords: Israel, Iran, Turkey, Saudi Arabia, Egypt.

\section{Introduction - The Middle East in the Shadow of the Rivalry between Iran and Israel}

In mid-winter of 2010 the "Arab Spring" broke out and spread all over the Arab world. It undermined the stability of many Arab countries and even toppled some regimes that had ruled with an iron fist for decades. At its height, it even brought into question the validity of the borders on the map of the Arab Middle East, which had been fixed by the 1916 "Sykes-Picot Agreement" and held up during the whole course of the 20th century. For a moment, it seemed as if the Arab world was following in the footsteps of other parts of the world, like Eastern Europe or South America, where restless young people led processes of change and even democratization.

However, the Middle East has its own way of doing things. The initial progressive liberal upsurge was replaced by an Islamic tendency advanced by the Islamic forces in region, and the initial protests and revolutions degenerated into bloody civil wars. These led to instability, dangerous insecurity, and in some cases complete chaos. Finally, nearly a decade later, the storm of protest, rebellion, and revolution triggered by the "Arab Spring" has subsided. Many Arab

'Professor and Vice Rector, Tel Aviv University, Israel. 
states, like Tunisia and Egypt, returned to the same situation they had known before the storm struck. In other states, like Yemen and Libya, the "Arab Spring" ultimately led to the collapse of the state institutions and a situation of prolonged anarchy, which still prevails at the time of this writing (Lynch 2012).

In its early stages, the "Arab Spring" was perceived as a positive and welcome outburst of vitality that would lead to a revival of Arabism, that is, the promotion of Arab unity, culture, and identity. The uprising was seen as an expression of the young Arab generation's determination to put the Arab world, and in particular, its Sunni segment, back on the map after several decades during which Arab states sank into themselves (Korany 2012). They had done so in large part on account of the social and economic hardships they suffered and the intervention in their affairs of foreign players, both international and, especially, regional, like Iran, accompanied by Turkey.

Iran was perceived as the state most likely to lose its status or, at the very least, to be damaged by the "Arab Spring". After all, Iran had been working for many years already to become a leading power and source of influence all over the Middle East, and beyond as well, by exploiting the weaknesses of the Arab countries. Many observers in the region tended to view Iran as the representative of the Shi ite Muslims, so its rise to prominence was considered to be a manifestation of the strengthening of the Shi ite camp in the world of Islam. The "Arab Spring", however, which, as noted, was initially perceived as an effort to restore the glory of Arab culture and identity, looked like it would damage and perhaps even block Iran's efforts to increase its influence in the Middle East (Tisdall 2011).

Israel was also perceived as an actor that would be damaged by the "Arab Spring". This was because the upheavals led to the collapse of regimes that were considered to be allies of Israel, and first of all, the regime of Egyptian President Hosni Mubarak. The trend that soon emerged and witnessed Islamic movements strengthening their position - like the Muslim Brotherhood, which seized power in Egypt and held it for almost a year - was also viewed as a development packed with negative and threatening implications for Israel (Friedman 2011).

However, ultimately, the "Arab Spring" not only failed to lead to setbacks for Iran or Israel, but on the contrary, enabled them to improve their status in the region. Both proved wise enough to exploit the chaos and the void created in the wake of the "Arab Spring" events. Thus, Iran took advantage of the chaotic local situations in Iraq and Syria, and in Yemen as well, to gain a foothold. This strengthening of Iran was perceived by many Arab states, first and foremost, the Gulf states led by Saudi Arabia, as a threat to themselves. They thus turned to Israel, which they viewed as an important regional player and even as a possible ally and strategic partner vis-à-vis the growing threat from Teheran.

This contributed to bringing about the establishment of a strategic alliance between the Jewish state and several of the Arab states, led by Saudi Arabia and some of the Gulf States, as well as Egypt and Jordan. This alliance, based upon common interests, is quite reminiscent of the "Alliance of the Periphery" established toward the end of the 1950s, although, perhaps ironically, as its exact reverse. The 1950s version called for Israel to develop close strategic alliances 
with non-Arab Muslim states in the Middle East (in particular, Turkey, prerevolutionary Iran, and Imperial Ethiopia) to counteract the united opposition of Arab states to the existence of Israel and the rising power of Egyptian President Gamal Abd al-Nasser, in particular. In stark contrast, the present version of the alliance is not directed against Egypt. Rather, Egypt is one of its important Arab partners. All the members are united by their fear of Iran's ambitions, and perhaps also by their resentment of Turkey's ambitions for hegemony, and by their desire as well to combat and put an end to the Islamic terror that has arisen in the Arab lands. It goes without saying that this new alliance received additional impetus and significance due to United States President Donald Trump's decision to withdraw American forces from Syria. Trump took this step as part of the general process of detaching the U.S. from the Middle East that began during the previous Administration of U.S. President Barack Obama.

True, the current alliance between Israel and some of the Arab states has limitations and weaknesses, and a kind of glass ceiling that the participants will find it difficult to overcome, especially in the absence of any progress in the Israeli-Palestinian peace process. Still, from this new alliance we can learn a great deal about the changing face of the Middle East and the transformation of Israel's relations with the Arab world. The latter have passed from opposition and hostility to reconciliation and a preparedness to coexist, and from there to cooperation up to the point of forming a strategic alliance. This alliance, moreover, opens the possibility of laying the foundations for wider regional cooperation in the Mediterranean Basin, for both Israel and the Arab countries. Thus, for example, both Israel and Egypt have strengthened their ties with Cyprus and Greece.

\section{Israel and the Arab World - from War to Peacemaking}

In May 1948, the British Mandate on Palestine ended and the State of Israel was born. According to the partition resolution of 1947 an Arab state was to be established alongside it, but never was. Since its' born, Israel's place in the Middle Eastern system and its relations with surrounding Arab countries have been the focus of research by Israeli and Arab researchers as well as researchers from outside the region. The question at stake was a complex one, involving political, ideological and cultural layers. It was political scientists who as early as the 1950's and 1960's laid the theoretical foundations for examining the Middle East as a separate entity, a separate system or an "international subordinate system" with its own characteristics and modes of operation (Binder 1958, Cantori and Spiegel 1970). Those included Israel as a legitimate player in the system. Subsequent researchers considered Israel's Involvement in the inter-Arab system on the basis of the assumption that the role Israel plays in that system is at once unifying and separating, stabilizing and intervening (Perry 1984, Podeh and Kaufman 2006).

Israel's birth in May 1948 was preceded by a violent conflict between the Jewish and Arab populations of British Mandate Palestine that started already 
in November 1947 following the adoption of the partition plan by the UN. When the new state declared its independence it was invaded by the armies of the surrounding Arab states. The 1948 war ended with a severe defeat for the Arab side. Hundreds of thousands fled, and some were expelled, from the territory that became the State of Israel. They became refugees who settled all over the Arab world, and until this very day no solution has been found for them, whether by returning to the places of their birth, or moving to the territories governed by the Palestinian Authority, or becoming settled in the countries where they presently reside.

The War also ended in the defeat of the regular armies of the Arab states that invaded the Jewish state. The fighting ended in 1949 with the signing of shaky Armistice Agreements with the Arab states of Egypt, Lebanon, Jordan, and Syria. The agreements did not prevent the continuation of hostile and violent acts during the following years, mostly by refugees or Palestinian fighters (Fedayeen) who penetrated into Israeli territory (Rabinovich 2003).

The next round of fighting between Israel and the Arabs, or more precisely, Egypt, the biggest Arab country, was in 1956. Israel joined Britain and France in their efforts to overthrow the regime of Egyptian President Gamal Abd elNasser, following his decision to nationalize the Suez Canal and draw close to the Soviet Union. Israel defeated the Egyptians in the military conflict in the Sinai desert. This led to significant political achievements for the Jewish state. First of all, a shipping lane was opened up through the Red Sea to Israel's southern port town of Eilat. In addition, United Nations Observers were deployed along the Israeli-Egyptian border to ensure the quiet. At the same time, however, Nasser improved his status in the Arab world. This was because he was perceived as the victor in the confrontation with England and France, the two colonial powers that had ruled the Middle East high-handedly in the past. After all, Nasser had succeeded in remaining in power despite their attack, and he was able to compel his attackers to withdraw their forces from Egyptian territory (Louis and Owen 1991).

\section{The "Alliance of the Periphery"}

One can understand why the 1950s are considered Nasser's greatest hour, as well as a glorious moment for Arab nationalism. Under Nasser's leadership Arab ideology became predominant throughout the region; millions embraced it. For a while it even seemed as if there was no power that could prevent Nasser from establishing himself, or at least his influence, over the whole Arab world (Vatikiotis 1978).

Israel's Prime Minister, David Ben-Gurion, became gravely concerned in face Nasser's rising popularity and the increasing influence of the Arab nationalism he advocated. Ben-Gurion thus sought other states that felt the same threat and would be willing to cooperate with Israel against Nasser. He found such allies in states on the region's periphery: Ethiopia in the south, Turkey in the north, and Iran in the east. Some Arab monarchies, like Morocco and Saudi Arabia, also established 
very clandestine, and sometimes indirect, affiliations with Ben-Gurion's already relatively covert alliance (Alpher 2015).

The "Alliance of the Periphery" had its own limitations. Each of the partners was relatively weak, especially in face of Nasser's rising power. Furthermore, their willingness to cooperate with each other was limited from the very beginning. Still, the Alliance did give its members some feeling of security, and even some tactical advantages. Thus, for example, the partners exchanged intelligence information about the Egyptian ruler's intentions. In some instances, they even assisted each other in supplying weapons. For example, during the 1958 civil war in Lebanon, Israel enabled Iran to transfer weapons via Israeli territory to the Shi ites in south Lebanon. The aim was to encourage the Shi ites to support the pro-Western administration of Lebanese President Camille Chamoun against his opponents, most of whom supported the pro-Nasser camp in the country (Erlich 2000). Later, in the early 1960s, Israel granted indirect assistance to rebels in Yemen in their war against Nasser, with the closed-mouth knowledge of Saudi Arabia. Indeed, the Saudis were the main supporters of the Yemeni rebels in their struggle against Nasser at the time (Orkaby 2015).

It was clear, however, that the "Alliance of the Periphery" was incapable of changing the regional situation fundamentally. This was not a formal alliance institutionalized by agreements. It remained relatively covert and secretive. In general, the sides maintained secrecy, being concerned that publicity would only harm them. Insofar as Israel was concerned, even though it was one of the major factors urging the establishment of the alliance, this was not enough to affect its status in the region, so it remained a marginal, and even weak, player.

We note that apart from all this, it seems that there was a great deal of exaggeration in the perception of Nasser as all-powerful and a threat to regional stability. After all, his high point in late 1956 was also the starting point of his decline. That decline did not begin in the wake of the June 1967 Six Day War defeat, but rather much before this, on account of Nasser's failure to resolve Egypt's social and economic problems or achieve Arab unity throughout the Arab world. In any case, the weakening of Nasser and the decline of Arabism found clear expression in the Arab defeat of June 1967. The "Alliance of the Periphery" now became superfluous from the point of view of both Israel and its partners. Some of the latter, like Saudi Arabia and Iran, even began to improve their relations with Egypt, which ceased being perceived as an enemy.

We should note in passing that the "Alliance of the Periphery" was just one aspect of Israel's much broader efforts to find allies in the region and outside it. In addition to establishing ties with the "Periphery Alliance" states, Israel also developed ties, and even extended assistance, to other actors. The Kurds in Iraq, who were fighting the regime in Baghdad, were one of these. The black Christian majority of South Sudan, who were fighting the central government in Khartoum, also received Israeli aid. In Lebanon, Israel continued its long-term efforts to establish ties with a number of the various forces in the country, but mainly with parties in the Maronite camp. 


\section{The Decline of Arabism, the Weakening of the Arab States, and the Rising Power of Iran and Turkey}

The late 1960s were marked by the decline of Arabism as a leading force in the Arab world. Egyptian President Nasser's death in September 1970, and even before this, the defeat suffered in the Six Day War, heralded the end of the era of Egypt's efforts to gain influence and even hegemony over the Arab world. The ideology of Arabism, which failed in both its efforts to bring about the unification of the Arab people and to defeat Israel, was replaced by competing ideologies and worldviews, the leading one being Islam. The weakness of Arabism stemmed mainly from the fact that all the Arab countries were becoming ever more embroiled in their domestic social and economic problems. This led each Arab country to concentrate on and give preference to its own particular state interests at the expense of all-Arab interests (Ajami 1978). The result was limited readiness, at least among some of the Arab states, to settle the conflict with Israel and advance mutual political and even economic relations (Sela 1998).

The first Arab state to act in this direction, as is well-known, was Egypt, in the late 1970s, under the leadership of President Anwar Sadat. He went so far as to sign a peace agreement with Israel. The new situation also found expression in the Arabs' willingness to take part in the Arab-Israeli peace process initiated by the United States at the beginning of 1991, after the liberation of Kuwait from Iraq in the Gulf War. The first major event in the peace process was the October 1991 Madrid Conference. It led to the Israeli-Jordanian Peace Treaty (signed in 1994) and the Israeli-PLO Oslo Accords (signed in 1993 and 1995). In the late 1990s, however, the Israeli-Palestinian peace process had run into difficulties on account of the unbridgeable gap between the positions of the sides to the conflict (Quadnt 2005).

Israel was not the only player to benefit from the changes taking place on the map of the Middle East early in the $21^{\text {st }}$ century. During the first decade, two old-new regional powers came to prominence in their efforts to advance their standing in the region, namely, Turkey and Iran. These states are perceived in the region as heirs to two older, long-lived, and rival empires, Turkey, heir to the Ottoman Empire, and Iran, heir to the Persian (Safavid, then Qajar) Empire, which ruled over and battled for dominance in the Middle East for nearly 500 years, from the beginning of the $16^{\text {th }}$ century. World War I put an end to the two old empires, as Britain and France became the dominant powers in the region.

In recent decades, however, Iran and Turkey seem to have gained the opportunity to renew their greatness. Turkey's fate became linked with Recep Tayyip Erdogan, the charismatic leader of the AK Parti. He has succeeded in providing Turkey with political stability, and under its umbrella, with economic prosperity as well. Unlike the leaders of previous Turkish governments, in fact, unlike all the governments since the days of Mustafa Kemal Atatürk, founder of the modern Republic of Turkey in 1923, Erdogan views the Arab and Muslim lands as a preferred field of action. He attempts to exploit the Muslim character of his political party and the weaknesses of the Arab states, as well as the fact 
that Muslim parties associated with the Muslim Brothers have gained strength in them, in order to promote Turkey's position in the Arab world.

Iran also seeks to benefit from the changes occurring in the Middle East. For many decades, going back at least to the time of the Shah, before the ayatollahs, or perhaps even earlier, Iran has had aspirations to gain influence, and even hegemony, over the region, or at the very least, to establish a security belt stretching from the Iranian Heights to the Mediterranean Sea. It goes without saying that Iran benefitted from both of the United States' wars in the region, in Afghanistan (winter of 2001) and Iraq (spring of 2003). This is because the Taliban regime in Afghanistan and Saddam Hussein's regime in Iraq were both tough foes of Iran, and as if in a flash they were eliminated by Washington (Saikal 2019).

Since Iran is a Shi ite country acting in the name of Shiite Islam and expressing commitment to the export of the Islamic revolution to Shi ite communities in the region, its rise to greatness was and is perceived as the rise of that school of Islam at the expense of the Sunni Islam world. Saudi Arabia and other gulf states thus feel threatened on two fronts, first, by the fact that Iran is intervening in the affairs of the Shi ite communities in the Persian Gulf states, including their own, and second, by the clearly alarming fact that Iran is developing nuclear capabilities.

In view of Iran's rising many of the moderate Arab states, like those of the Gulf, started manifesting a greater willingness to expand cooperation with Israel. They became more open to accepting economic assistance and developing security arrangements vis-à-vis Iran. In fact, an Israeli-Gulf state dialogue was begun as early as the 1990s, in the shadow of the Israeli-Arab peace process being advanced by the U.S. In the framework of that dialogue, channels of political and security cooperation were opened between the two sides and trade and economic ties expanded greatly. Two of the Gulf states, Oman and Qatar, opened diplomatic offices in Israel and allowed Israel to establish similar offices on their territory. At the same time, other Arab states began establishing channels for dialogue with Israel (Miller and Zand 2018).

Toward the end of the 1990s, the Israeli-Palestinian peace process came to a dead end. The failure to advance Israeli-Palestinian peace agreement, was followed by a renewal of rounds of violence between the latter two sides. All this blocked, and even set back relations between Israel and the Gulf states, which made it clear that the weak point in their relationship with Israel was their concern over how matters between Israel and the Palestinians were proceeding. Still, the lines of communication were not closed completely. The Gulf states, led by Saudi Arabia, continued in their efforts to put the peace process back on track. In this context, they placed various proposals on the table, the most prominent of which was the Arab Peace Initiative of 2002 (Fuller 2002). The warming relations with Israel found expression sometime later, in the summer of 2006, during the Second Lebanon War between Israel and Hezbollah. Many Arab states almost openly supported Israel in this fight.

Insofar as the Gulf States were concerned, the challenge was right in the Gulf itself, where Iranian antagonism was increasing perceptibly. It seems that 
these tangible difficulties with Iran served as the background for several Gulf States, led by Saudi Arabia, opening channels for dialogue with Israel, and even deepening and expanding them. There were reports, for example, of a meeting between senior Israeli officials, including then-Prime Minister, Ehud Olmert, and senior Saudi officials, including perhaps Prince Bandar bin Sultan. It was also reported that Mossad Head Meir Dagan visited the Saudi capital, Riyadh. Against this background, media reports multiplied about the development of cooperation and security coordination between Israel and Saudi Arabia in connection with the possibility of Israeli military action against Iran's nuclear facilities. Both sides hastened to deny these reports or refused to relate to them (The Guardian 2006).

\section{The "Arab Spring" and Its Failure}

The shockwave that overcame the Arab world during the winter of 2010 was unlike anything it had known for decades. Soon after it began this outburst of turbulence was termed the "Arab Spring." The use of this term reflected the high hopes, and even faith, of many in the Arab world and elsewhere for positive change. They hoped that the upheaval would lead to the collapse of the political and social arrangements existing in most, if not all, of the Arab states, which suffered from various serious maladies and defects. They hopeful looked forward to progress in the direction of democracy and enlightenment, political stability and economic prosperity, security and social justice.

The turmoil began in Tunisia and from there skipped over to Egypt. After them came the turn of Libya, Yemen, and finally, Syria. In Tunisia and Egypt the reigning presidents, Zayn Abadin Ben Ali and Hosni Mubarak respectively, fell from power. For a while, Islamic parties managed to take power. In the end, however, both Tunisia and Egypt returned to the same point they had been at the outbreak of the "Arab Spring". In Tunisia secular forces, some of which had held power under Ben Ali, returned to power. In Egypt the army came back and took control. This occurred in June 2013, when a military coup d'état led by the Minister of Defense, Abd al-Fattah El-Sisi, overthrew the regime of Muslim Brotherhood adherent, Mohamed Morsi. Sisi became president of the country. By contrast, the collapse of the ruling regimes in Libya and Yemen, brought about by the "Arab Spring", led to the collapse of their whole state systems and the outbreak of bloody civil wars.

In Yemen, in September 2014, forces loyal to the Houthi movement took over the government in the capital, Sana'a. The Houthi belong to the Shiite branch of Islam and are named after their founder, Hussein Al-Houthi. Iran became the main supporter of the Houthi in their battle for control of Yemen. The nightmare of the Saudis thus came to life, that is, their fear that Yemen, which is right in the Kingdom's backyard, would become a forward base for Iran. From there, very close by, Iran could threaten to fire missiles on Saudi cities. It could also try to block shipping in the Bab-el-Mandeb strait at the mouth of the Red Sea. 
Because of their concerns about Iran's deepening intervention on the side of the Houthi in Yemen and the aid it was giving to the Hezbollah organization on their territory, the Gulf states were moved to unify under the leadership of Saudi Arabia (Lewitt 2016). In March 2015 they launched the "Determination Storm Operation", which aimed, by means of attacks from the air, at blocking the Houthi takeover of Yemen and depriving the Iranians of the grip they hoped to achieve over the southern Arabian Peninsula and the entrance to the Red Sea. However, the Saudis failed to achieve a complete victory, and Yemen sank into a prolonged state of war, with the price being paid, as usual in the Middle East, by the civilian population of the country (Gordon 2018).

In Syria, President Bashar al-Assad survived the upheaval of the "Arab Spring", but in his struggle for survival he dragged the country into a prolonged and bloody civil war. The price paid was very high. Over half a million Syrians were killed and millions more became refugees. Bashar al-Assad's victory was finally achieved thanks to the involvement of Russia and Iran in the fighting, beginning in September 2015. While Russia struck at Assad's opponents from the air, Iran sent tens of thousands of fighters into Syria, some of them Shiite volunteers gathered from all over the Muslim world, including Iraq, Afghanistan, and Pakistan. Iran made no secret of its intention to establish its presence in Syria, which would continue even after the war ended. The aim was to make Syria part of the long-coveted land corridor leading straight from Tehran to Baghdad, then to Damascus and Beirut, thus establishing Iranian hegemony over this whole expanse (Harris 2018).

The outbreak of the "Arab Spring" was accompanied by the beginning of the end of a long period of "Pax Americana" in the Middle East. This had begun in the spring of 1991, in the wake of the Gulf War of that year, and gathered force with the collapse of the Soviet Union in December 1991. As the "Arab Spring" and the turmoil it produced were happening, America, under Presidents Obama and Trump, sought to detach itself from the region and its problems. In contrast to Washington, Moscow, under the leadership of President Vladimir Putin, found a way to return to the region and play a major role in redrawing its map and determining its character, in a manner that coincided with Russia's interests and age-old historical goals in the Middle East.

Russia did not act in a vacuum or as the only player in the Middle East arena. Serving the Russians as a platform and assistant were Iran and its proxies, all of whom were and are participants in the "radical axis," or "Shi ite axis," that took shape during the previous few decades. As we know, many in the region and abroad sought to see the "Arab Spring" as an expression of an awaking, or even rebirth, of the Sunni Arab expanse in face of the Shiite challenge that had risen up before it. The role Shi ite Iran was able to play in Syria (and elsewhere), however, meant that not only did the "Arab Spring" fail to bring about a weakening of the "Shi ite axis", but, on the contrary, reinforced it. Standing at the side of Russia and cooperating closely with it, Iran became an important player in wide areas of the Middle East (Bolan 2018).

In retrospect, then, it is clear that the Arab Spring actually strengthened Iran, which found a way, with the help of Russia, to exploit the disorder in the 
region in order to advance its own interests in Iraq, Syria, and Yemen. It is no wonder that Iran's moves caused anxiety in the Gulf States. In the face of Washington's tendency to disengage from the Middle East, the anxiety increased. As noted, the U.S. withdrawal began during the time of the Obama Administration, and President Trump has continued it at full speed. Obama was prepared to come to an agreement with Tehran on the nuclear question and did not conceal his desire to avoid using American power against Iran or anywhere else in the Middle East. Trump, for his part, decided to remove the American troops in Syria, thereby leaving most of that country to Russia and Iran, and the northern part to Turkey. Even as it withdrew the U.S. paid lip service to the leaders in the region, saying it would continue to be committed to their security. However, the fear that they could no longer rely on Washington to come to their aid pushed some of the Arab states, in particular the Gulf States, into the arms of Israel. At the same time, they also made efforts to strengthen their ties with Moscow (Hall 2019).

At this point we should note the role of Turkey, which is a large Sunni Muslim, but non-Arab, state. It could have served as the axis of a broad regional undertaking by the moderate and pro-Western Sunni states to stand up against and block Iran. However, that is not what happened. Turkey, in pursuit of its own interests, attempted to exploit the "Arab Spring" and later even ride the Islamic wave that inundated the Arab states for a while. Thus, the defeat of the Muslim Brothers in Egypt, Tunisia, and Syria was also a defeat for Turkey, which ended up only partially satisfied, having limited control over an area in northern Syria (Schanzer and Tahiroglu 2016).

Over and over again Turkish President Erdogan subjected his country's foreign policy to his own personal whims or his personal political interests, and his whimsical moves prevented Turkey from taking advantage of the on-going crisis to strengthen its position. This happened even though Ankara was not at all happy about its largest regional and Shiite competitor, Iran, growing stronger.

Characteristic of Turkey's behavior were the policies it adopted towards Israel and Egypt, both important regional players. Because of the way Turkey tried to use the Palestinian question, its relations with Israel became badly muddied. There was even a long break in relations because of the 2010 Turkish ship MV Mavi Marmara incident and Erdogan's subsequent wildly anti-Israel rhetoric. Regarding Egypt, Erdogan's refusal to recognize the legitimacy of the military coup led by Abdel El-Fattah El-Sisi against the government of the Muslim Brothers resulted in a rift and then a break in relations between the two countries.

The threating shadows cast by Iran and, in the view of some, Turkey, made it imperative for Israel and other nearby countries to increase their cooperation with each other. As in the old "Alliance of the Periphery" of sixty years previously, now too there was no institutionalized or formal alliance, but rather a series of collaborations, mostly relating to intelligence and security matters.

It should be noted that initially Israel took advantage of the war in Syria to attack and destroy weapons shipments from Iran to Hezbollah on Syrian soil, and later, also to attack installations representing Iran's efforts to establish 
bases on Syrian territory. Israel was successful, at least in part, insofar as Iran showed its unwillingness to enter into a direct and all-out confrontation with Israel by slightly withdrawing its forces from the Israeli-Syrian border. The determination shown by Israel in its struggle against Iran's becoming firmly based in Syria as well as its determination in its struggle against Iran's nuclear ambitions has been perceived by other countries as a success and an example to be imitated, and they are inspired by Israel's willingness to confront Iran (Ayman 2018).

Thus, Israel and Egypt have begun cooperating militarily to an unprecedented degree and closely coordinating their fight against the ISIS threat in Sinai. The Egyptian public has not changed its attitude toward Israel, but the Egyptian government has become committed and even willing to cooperate in military matters more than ever before. Thus, for example, it has been reported that Israel, in coordination with the Egyptian army, has attacked targets in Sinai manned by the ISIS branch there, and that Israel helps the Egyptian Army with intelligence in its war against the radical Islamists (Saleh 2019, Al-Jazeera 2019).

A political dimension has also developed in this expanding field of cooperation. For example, Israel showed its willingness to intervene with the Americans on the Saudis' behalf in the case of the killing of the Saudi journalist, Jamal Khashoggi, whose death was being blamed on the heir to the throne, Crown Prince Mohamed bin Salman. From their side, most of the Gulf states stood on Israel's side at the Warsaw "Conference on Peace and Security in the Middle East" sponsored by the U.S. in February 2019 (Holmes 2019). The Gulf States and many other Arab countries were also willing to be enlisted to help in the Americans' effort to promote an Israeli-Palestinian peace process, in order to remove this issue from the regional agenda. It has been reported in the media that these countries have been putting a lot of pressure on the Palestinian Authority, headed by Mahmoud Abbas, to cooperate with the efforts of the Trump Administration to advance its so-called "deal of the century," the American draft proposal for solving the Israeli-Palestinian conflict (Krasna 2018).

Economic relations must also be added to this expanding field of IsraeliArab cooperation. This economic dimension developed thanks to the discovery of natural gas fields along the Mediterranean coastline close to Israel. It was the first to discover and exploit these gas fields, which turned it into an important player on the international scene. Thus, Israel became the supplier of gas to Jordan after having already taken upon itself the obligation to supply the Kingdom with water. Israel also signed agreements to supply gas to Egypt (Macaron 2019). At the same time, efforts to make use of these discoveries for the purpose of improving relations with Turkey did not fare well. Because of Erdogan's hostility, no agreement to export Israeli gas to Europe via Turkey could be reached. As a substitute, Israel chose Greece and Cyprus as channels for exporting its gas to Europe. This economic decision was, in fact, part of a deeper system of ties that were being established between Israel and the two Greek-speaking countries, thanks in large part, undoubtedly, to their concerns over the challenges posed to them by Erdogan-led Turkey (Karbuz 2017). 
Similar to its behavior in the 1950s, Israel in the 2010s began to put together a system of relations with other countries that moved in the direction of a genuine regional alliance in face of the threats and dangers it and they saw themselves facing. As in the 1950s and 1960s, this was a system of relations, not an institutionalized alliance. However, there are clear differences between the 1950s and today. Israel today is a much more powerful and influential regional player than it was then, thanks to its economic and military strength and its relations with the rest of the world. The old 1950s "Alliance of the Periphery" arose at a time when Israel's relations with the U.S. were quite unstable. Today, in contrast, Israel is perceived as a close, solid, and even intimate ally of the American Administration.

In addition to maintaining ties with other actors inside the region, like the Kurds and the South Sudanese, historical allies of Israel, the Jewish state is also working to tighten its relations with Cyprus and Greece, as mentioned previously. Here Israel has an economic and a security interest. It wants to work with the Greek-speaking countries to develop energy resources, and especially the gas fields off the Mediterranean coast. Indeed, there are those who view Israel's relations with such countries as Azerbaijan, Greece, Cyprus, Ethiopia, and South Sudan, and even with other countries in Asia and Africa, as the real analogy to the "Alliance of the Periphery". Finally, there are also observers who would add to the above Israel's friendship with the states of the Visegrád Group (also known as the Visegrád Four or V4, a cultural and political alliance of the Central European states, Poland, Hungary, Slovakia, and the Czech Republic). The friendly relations with the latter came about thanks to the good personal relationships developed by Israel's Prime Minister, Benjamin Netanyahu, with the heads of state of the V4, but also thanks to those leaders' lack of trust in Brussels (as the capital of the European Union) (Ahren 2019).

\section{Conclusion}

During the seventy years of its existence, Israel's relations with the Arab world have experienced a radical turnabout. What began as deadly hostility to the existence of the Jewish state passed over into resignation and a willingness to coexist, even if this was the result of having no choice. Recently a new stage evolved, with some Arab states willing to develop ties of cooperation that point in the direction of a strategic security alliance.

In the 1950s Israel's partners were the non-Arab states on the periphery of the Middle East, which had to confront the rising Arab nationalism of the time and its undisputed leader, Gamal Abd el-Nasser. Sixty years later, the periphery states, or at least Iran, and to some extent, Turkey, have become influential players in the regional arena in such a way as to represent a challenge to Israel and many of its neighboring Arab states. Israel came into existence finding itself in a prolonged and apparently insoluble conflict with the Arab states, but now some of the latter have become Israel's partners in face of the Iranian threat and the Turkish challenge. 
Like the old "Alliance of the Periphery", the current cooperation is marked by clear limitations. First, there is the lack of ability and, it seems, a lack of willingness as well, to make the existing ties public. There is also a lack of willingness to advance beyond the development of security ties between the states' rulers and security establishments to the stage of normalization and a warm peace between the sides.

The present "alliance" reflects the changing face of the Middle East and the deep processes it is undergoing. At the head of these is the decline of Arabism and the decline of the Arab world, while on the other side, Iran and Turkey, and Israel too, are rising in influence and power. Indeed, it is these three countries that today dictate the path the Middle East will take.

The main focus at present is on Iran, but Israel and a number of the Arab states have shared political and security interests apart from Iran. In addition, there is the possibility of expanding the existing cooperation beyond the political aspects that touch the states of the Middle East exclusively. This is attested to by the fact that states like Cyprus and Greece are willing to participate in a direct alliance with Israel and economic cooperation with Egypt.

This development may have been accelerated by the Arab Spring but is not its direct result. It's focus is the conflict with Iran but it has the potential to develop beyond it, as the players involved have political and security interests in common. The involvement of countries such as Cyprus and Greece in a direct alliance with Israel and the economic involvement of Egypt, too, indicate the ability to extend this cooperation to issues beyond political aspects relevant to the Middle East alone .

Should Israel and its partners in the set-up of alliances and understandings now taking place in the Eastern Mediterranean conduct themselves wisely, stability in the region may be enhanced, and efforts for peace promoted. It might also yield significant economic revenues to all regional players. At the same time, should the status quo be preserved instead of moving ahead peace efforts, or even serve as the basis for a provoking or confronting common rivals, like Iran, rather than deter them, the result might be instability in the region that can be developed into rounds of violence. Such a pessimistic scenario might destabilize the foundations of the new peripheral alliance Israel had established with its neighbors which in any case has its limits, to begin with the fact that its being based more on particular interests of regimes and countries and lacks wide public support, as distinct from acceptance, at least on the part of public opinion in the Arab world.

\section{References}

Al-Jazeera (2019) Sisi: Egypt, Israel in close cooperation against Sinai fighters. Retrieved from https://bit.ly/2GwZVz2. [Accessed 5 January 2019]

Ahren R (2019) Israel to host 4 Central European leaders, including Hungary's Orban, Visegrad Group's February summit in Jerusalem marks first meeting of consortium outside of Europe. The Times of Israel. Retrieved from https://bit.ly/2W2nxSC. [Accessed 28 January 2019]. 
Ajami F (1978) The End of Pan-Arabism. Foreign Policy. Winter 1978/79 Issue. Available at https://www.foreignaffairs.com/articles/yemen/1978-12-01/end-pan-arabism.

Alpher Y (2015) Periphery, Israel's Search for Middle East Allies (Hebrew). Tel Aviv: Matar Publishing House.

Ayman DI (2018) Will Israel and Iran go to war in Syria? The Brookings Institute. Retrieved from https://brook.gs/2SAnITc. [Accessed 5 October 2018].

Binder L (1958) The Middle East as a subordinate international system. World Politics 10(3): 408-429.

Bolan, C. J (2018). Russian and Iranian "Victory" in Syria: Does It Matter?. The Foreign Policy Research Institute. Retrieved from https://bit.ly/2SyUPax. [Accessed 20 December 2018].

Cantori LJ, Spiegel SL (1970) The International Politics of Regions: A Comparative Approach, 1-41. Englewood Cliffs, NJ: Prentice-Hall.

Erlich R (2000) The Lebanon Tangle, The Policy of the Zionist Movement and the State of Israel towards Lebanon, 1918-1958 (Hebrew), 488-491. Tel Aviv: Ma'arachot.

Friedman TL (2011) Postcard From Cairo, Part 2. The New York Times. Retrieved from https://www.nytimes.com/2011/02/13/opinion/13-friedman-Web-cairo.html. [Accessed 13 February 2011].

Fuller GE (2002) The Saudi Peace Plan: How Serious. Middle East Policy Council, Volume IX, Number 2. Available at https://www.mepc.org/saudi-peace-plan-howserious.

Gordon P (2018) Saudi Arabia's war in Yemen has failed. The Washington Post. Retrieved from https://wapo.st/2L6pZqy. [Accessed 12 November 2018].

Hall R (2019) Trump Says Syria is 'Sand and Death' in Defence of Troop Withdrawal. The Independent. Retrieved from https://ind.pn/2XvwvIu. [Accessed 3 January 2019].

Harris W (2018) Quicksilver War, Syria, Iraq and the Spiral Conflict. London: Hurst.

Holmes O (2019) Do Netanyahu's Smiles with Arab leaders Signal a New Era?. The Guardian. Retrieved from https://bit.ly/2DFIWZY. [Accessed 14 February 2019].

Miller AD, Zand H (2018) Progress Without Peace in the Middle East. The Atlantic. Retrieved from https://bit.ly/2KUqB2h. [Accessed 1 November 2018].

Saleh H (2019) Egypt tries to block airing of Sisi's '60 Minutes' interview. Financial Times. Retrieved from https://www.ft.com/content/320a08d0-11bc-11e9-a581-4ff7840452 4e. [Accessed 6 February 2019].

Karbuz S (2017) East Mediterranean Gas: Regional Cooperation or Source of Tensions?. Barcelona Center for International Affairs, May 2017. Available at https://www.cido b.org/es/publicaciones/serie_de_publicacion/notes_internacionals/n1_173/east_medit erranean_gas_regional_cooperation_or_source_of_tensions.

Korany B (2012) Egypt and beyond: The Arab Spring, the New Pan-Arabism, and the challenges of transition. In B Korany, R El-Mahdi (eds) Arab Spring in Egypt: Revolution and Beyond. Cairo: Cairo University Press. Available at http://cairo.uni versitypressscholarship.com/view/10.5743/cairo/9789774165368.001.0001/upso-978 9774165368-chapter-14.

Krasna J (2018) Israel and the Gulf States: Some Things Change, Some Stay the Same. The Jerusalem Institute for Strategy and Security (JISS). Retrieved from https://bit.ly/2viE M6x. [Accessed 29 November 2018].

Louis WMR, Owen R (eds) (1991) Suez 1956: The Crisis and its Consequences. Oxford: Oxford University Press.

Lynch M (2012). The Arab Uprising: The Unfinished Revolutions of the Middle East. New York: Public Affairs. 
Macaron J (2019). The Eastern Mediterranean Gas Forum Reinforces Current Regional Dynamics. Arab Center Washington DC (ACW). Retrieved from https://bit.ly/2GBl csT. [Accessed 25 January 2019].

Orkaby A (2015) The 1964 Israeli Airlift to Yemen and the Expansion of Weapons Diplomacy. Diplomacy \& Statecraft 26(4): 659-677.

Perry EG (1984) Israeli Involvement in Inter-Arab Politics. International Journal of Islamic and Arabic Studies 1: 11-1 .

Podeh E, Kaufman A (2006) Arab-Jewish Relations: From Conflict to Resolution?, 93113. Portland: Sussex Academic Press.

Quandt WB (2005) Peace Process: American Diplomacy and the Arab-Israeli conflict since 1967. Washington DC: The Brookings Institution.

Rabinovich I (2003) Waging Peace, Israel and the Arabs, 1948-2003. Princeton: Princeton University Press.

Saikal A (2019) Iran Rising: The Survival and Future of the Islamic Republic. Princeton: Princeton University Press.

Schanzer J, Tahiroglu M (2016) Ankara's Failure, How Turkey Lost the Arab Spring. Foreign Affairs. Retrieved from https://fam.ag/1K8uYjJ. [Accessed 25 January 2016].

Sela A (1998) The Decline of the Arab-Israeli Conflict: Middle East Politics \& the Quest for Regional Order. Albany: State University of New York Press.

The Guardian (2006) Israel 'held secret talks with Saudi royal family. Retrieved from https://www.theguardian.com/world/2006/sep/25/saudiarabia.israel. [Accessed 25 September 2006].

Tisdall S (2011) Iran has been isolated by the Arab spring. The Guardian. Available at https://www.theguardian.com/commentisfree/2011/may/17/iran-arab-spring.

Vatikiotis PJ (1978) Nasser and His Generation. New York: St. Martin's Press. 



\title{
A Mediterranean Lesson for Contemporary Architecture
}

\author{
By Giorgia De Pasquale*
}

\begin{abstract}
Mediterranean landscape has been a great muse for artists of all ages. During the XX century, architects used the Sea - and the land lapped by the sea - as a reservoir of ancient knowledge, using the journey as a tool in a fluid experimentation laboratory in which new ideas about spaces, forms and sites were born. In this paper, I aim to discuss the XX century's Mediterranean lesson in Architecture, following the journeys of Gunnar Asplund, Le Corbusier, Josep Lluis Sert, Louis Kahn, Dimitris Pikionis, Giuseppe Pagano, and Alvar Aalto. Some topics emerge by comparing tracks, paths, attentions and sketches: the adherence of sections to the site, the determining influence of climate in the planning process, the geometric simplification of volumes, the relationship with light, the coincidence of forms of life and spatial structures. We can read these constants as an immaterial patrimony that, in the historical-geographical interpretation of Mediterranean «longue dureè» made by Braudel, tries to deconstruct the myth by decomposing it into architectural archetypes that come up to our days.
\end{abstract}

Keywords: Architecture, Mediterranean, Journeys, Drawings, Landscape.

\section{Introduction}

The Mediterranean area finds its unity in a rich iconographic variety, in a metaphysical place out of time (Braudel 1990). This kind of Mediterranean, a cultural and mythopoeic Mediterranean, was very used by people in the XX century to develop a new, free and modern architecture.

In this paper, I follow the history of this cultural process, analysing eleven journeys made by eight architects in the first half of 1900 century in the Mediterranean area. Notes, sketches, drawings and photographs have been gathered; tracks, paths, attentions and topics have been compared to find the archetypes from which a new Mediterranean culture was born.

\section{Volumes under Light}

Light is essential to all architectures but in the Mediterranean it becomes a key to discover the essence of forms.

"Méditerranée, reine des formes et de lumière. La lumière et l'espace. Le fait, c'est le contact pour moi en 1910 à Athénes. Lumiére décisive. Volume décisif: l'Acropole" (Le Corbusier 1965: 7).

Le Corbusier discovers the importance of light in the planning process during his Voyage d'Orient. On May 20th 1910 he leaves from Berlin and arrives in Istanbul on July 5th, passing through Dresden, Prague, Vienna, Vacz, Budapest,

\footnotetext{
${ }^{*}$ Research Fellow, Department of Architecture, Roma Tre University, Italy.
} 
Baja, Giorgavo, Belgrado, Jnajevaz, Naitscha, Bucarest, Tirnovo, Galvoro, Schipka, Kasanlic, Adrianopoli, Rodosto and Mount Athos. On the 7 September he lands in Daphne and then reaches Athens through the Aegean Sea. He is in Athens from the 14 to the 27 September and then goes to Itea, Delfi and Patrasso. He embarks towards Brindisi, from where he heads up the Italian peninsula travelling through Naples, Pompei, Rome, Tivoli, Florence and going back home via Lucerna. His sketches of the Voyage d'Orient continuously describe what the same architect will later call "the conscious, correct, and magnificent interplay of volumes assembled under light". Not "through" light, but "under" it. Matter expresses a passive role, while the inclination of every ray and its intensity determine the appearance of a space. A unity of landscape shows thanks to light, like the mass of the Parthenon, or the in-between spaces of the Caracalla roman thermal baths.

In the Mediterranean area, architects generate a utopian desire to relate buildings to the plastic way surfaces appear to react under light; while political, religious or ideological factors are overshadowed. It's a new revolutionary aesthetic value that fascinates architects that travel across the Mediterranean Sea, a new value based on ruthless, warm, strong light and precise, sharp shadows. The Mediterranean light shows itself with the intensity of an incision, like when it meets a musharabia, a celosia, or later on a brise-soleil; shadows draw lines and beat time.

In the sketches that Le Corbusier makes in Rome, at Caracalla (Figure 1), the relationship between light and shadows is sharp in the contraposition between dark and heavy masses, and light and fluid voids. The architect draws the masses of walls, heavy and oppressive; meanwhile a warm bright light, made with a yellow pencil, makes the space vibrant and beats the rhythm of the day. The drawing shows the shakiness of the void, which changes visions and proportions because of time, ray inclination and the fading of the contrasts between day light and shadows.

Figure 1. Le Corbusier, Caracalla, 1911

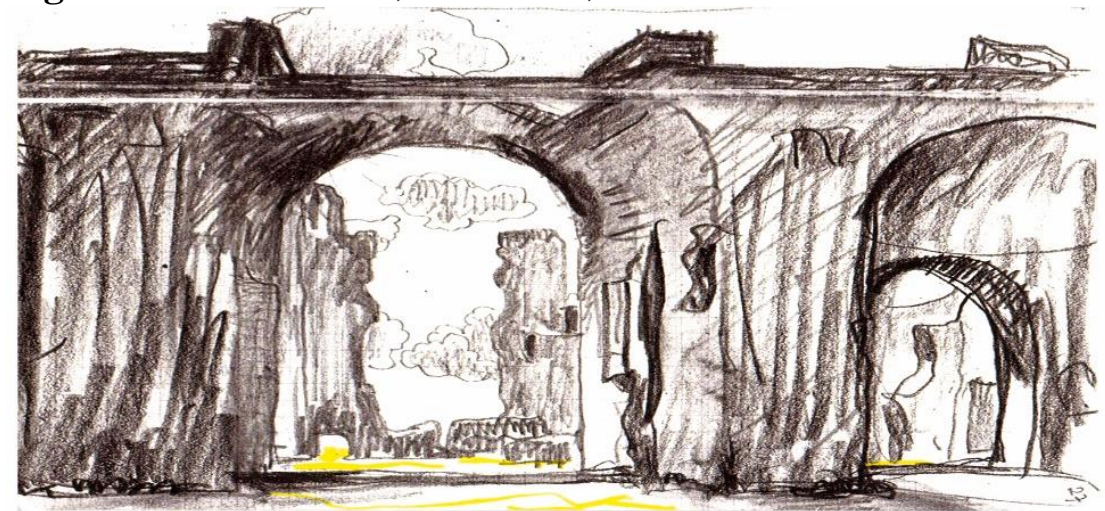

Source: Lotus International, 68, 1991. 
We can see the same attention to the topic of light in architecture in the travel notes and sketches made by Luis Kahn, 40 years after Le Corbusier Voyage d'Orient. In 1950, the architect stays at the American Academy in Rome, visiting many Italian cities like Siena, Florence, Pisa and Venice. In January 1951, Kahn heads to Cairo with a small group of residents at the Academy. From Cairo, they take the train to Aswan and from there the boat to Luxor, Karnak, Deir elbahari and Saqqara. At the beginning of February, they leave for Greece. Kahn stops in Athens. In front of the Parthenon he draws a view with crayons, describing it in its majesty and fullness: a mysterious winter light, a few clouds and the rest of the city just sketched. The sketch underlines the relationship between light and wall mass. Together he writes: "when we think of great buildings of the past that had no precedent, we always refer to the Parthenon. We say that it is a building that grew out of the wall with opening. We can say that in the Parthenon light is the space between the columns (a rhythm of light, no-light, light, no-light) which tells the tremendous story of light in architecture that came from the opening in a wall" (Kahn 1951: 484).

In these Mediterranean journeys, the space becomes more and more absence of material. In this system, taking out material means giving shape to the box, and defining the evolution that light will follow. This discovery defines a planning method: space comes from the subtraction of matter. A horizontal subtraction of material links the inner space of a building to the landscape; a vertical subtraction defines the exclusive relation of the patio that connects the inner space to the sky, and cuts out the surrounding landscape. Each subtraction seems to give a proper answer to a precise task and an innovative appearance to volumes. So, in the planning process, different height openings-in-the-wall substitute the classic window. Architecture becomes a play of "mirabili soluzioni in termini di pieni e di vuoti" (Pollini 1933: 35). The Austrian architect Bernard Rudofky journeys to Greece, Turkey and Italy between 1924 and 1934 and stops to live in Capri for two years (1932-1934). In 1935 he writes that windows are "miserables" and "bourgeois" and he analyses the differences between Nordic and southern ones: "nei paesi meridionali le finestre sono poste all'altezza dei sedili, queste sono ancora le più simpatiche (vi sono sedute delle donne con occhi ardenti). Nelle regioni più nordiche la finestra incomincia dalla mezza persona in su. Lassù è la preferita di uomini sazi che tentano di riempire l'apertura con la testa appoggiata" (Rudofsky 1938).

A consequence of this way of thinking about light and volumes is a reflection on the power of indirect and broken light, as we can see in the sketches of the Canopy (Figure 2) Le Corbusier makes in Villa Adriana. This fascination is clear in his following projects: La Tourrete, Notre Dame du Haut chapel in Ronchamp, Villa La Roche, etc.

An interpretation of the different use of holes can also be seen in another Mediterranean traveller: Adolf Loos' Venetian project for Villa Moissi. Here the architect does not use a regular and symmetrical composition of the facades, but he measures the openings based on the sun: regular windows towards west, balconies and terraces to the east. The south wall is totally blank; to the north small openings guarantee ventilation, thanks to the difference of temperature between 
the two opposite façades. Natural light reaches every room, even if through informal ways, like the small openings on the western facade or the terrace skylight. In its three dimensional modelling, the volume seems to be crossed with light, as if it were a fluid element able to reach even the most remote part of the house.

Figure 2. Le Corbusier, Villa Adriana, 1911

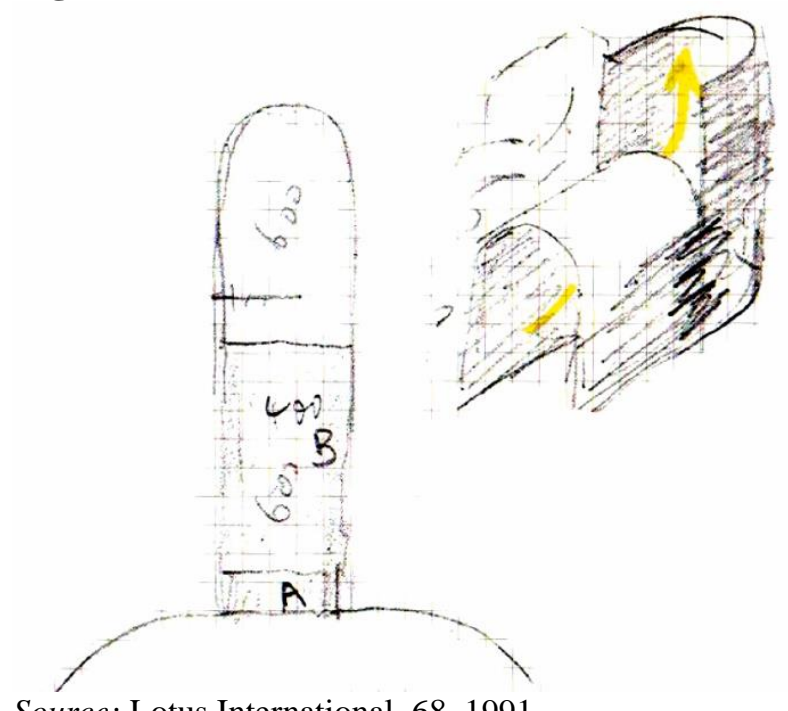

Source: Lotus International, 68, 1991.

Figure 3. Lluis Sert. Casa en el Paseo de la Muralla, Ibiza, 1961

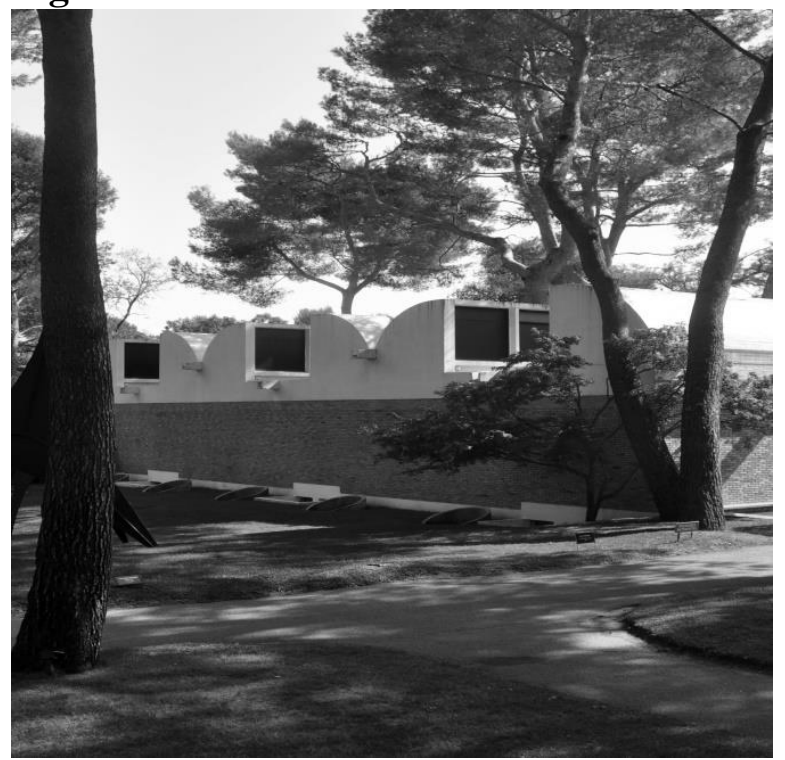

Source: Capitel A., José Luis Sert, Universitad De Valladolid, 2002.

Slight variations of intensity measure the inner spaces. Ibiza dwellings, Mirò Museum and the Maeght Foundation by Lluis Sert (Figure 3), La Tourette by Le Corbusier (Figure 4) or Casa Gilardì by Luis Barragan (Figure 5), have the same natural light coming unexpectedly from above, to generate a metaphysical space. It 
is an inclusive and introvert architecture, which eliminates any possibility of orientation and shows the rhythm of day, where light is a protagonist.

Using the light as a plastic material, architecture becomes a transitional space: from light to shadow, from light to dark, from white to black or, with the words of Spiros Papoalukàs, from light, to dark and "half-light".

Figure 4. Le Corbusier. Convent of La Tourette, 1957

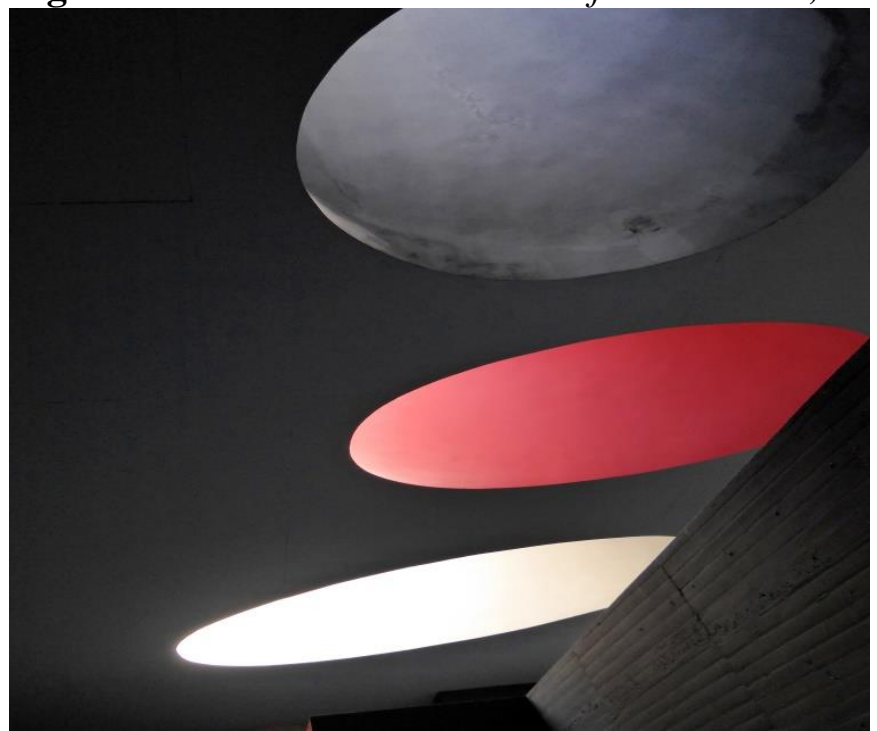

Source: Photo by V. Palmieri.

Figure 5. Luis Barragan. Gilardì House, 1975

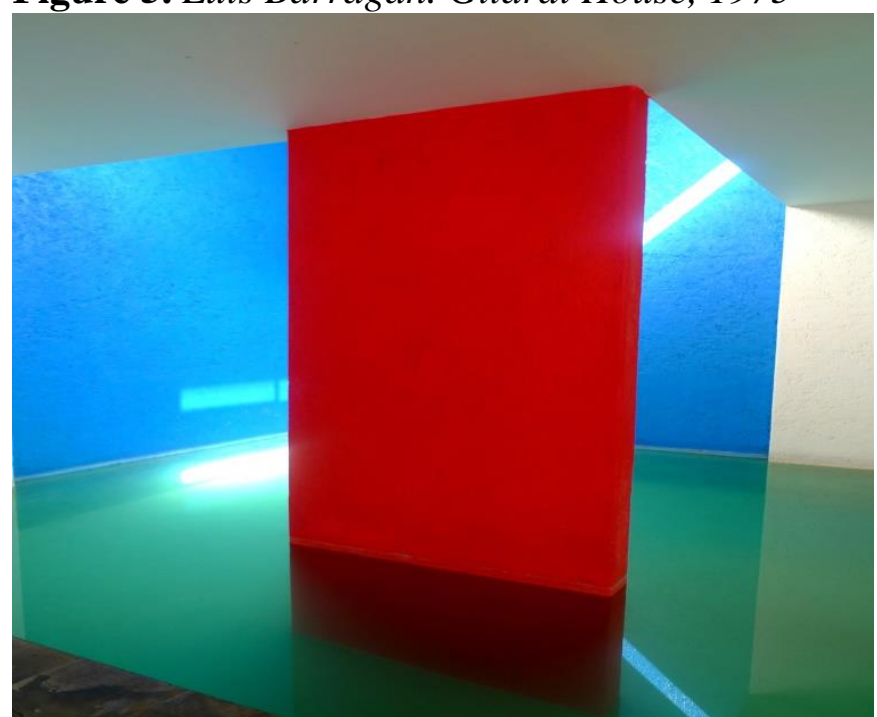

Source: Martinez A. R., 1902-1988 Luis Barragan, Electa, 1996.

\section{Deep-Rooted Architecture}

In the Mediterranean, mountains arrive to the sea. As Fernand Braudel explains, these are young mountains, tall and moved: Alps, Apennines, Balkans, Tauro, Lebanon, Atlas, Pyrenean. Geology, together with a long history of suffered 
drainages, and a slow organization of fair areas always threatened by malaria, explains the paradox that near the Mediterranean area the history of mankind began on mountains and hills. This characteristic influences architecture. Cities are built up on cliffs, laid on rocks, far away from epidemics and incursions. This feature in the geological and historical data affects above all the architects who come from Northern Europe.

In November 1913, Gunnar Asplund (Stockholm, 1885-1940) leaves toward Italy and Tunis. He stops in Rome for nearly a month and then goes to Naples. Along his way, he writes in his notebook: "The road from Rome to Naples is incredibly lovely as it makes its way through the mountains. Vineyards and vineyards and little towns huddled high up the slopes, their roofs and walls and church towers forming the very crests, a rich and peaceful line" (Gunnar 1915).

In 1924, the Finnish architect Alvar Aalto (Kuortane, 1898 - Helsinki, 1976) travels to Italy for the first time and he is impressed by the relationship between anthropological space and morphological characters in the landscape. The architect is charmed by the hard ruthless orography: Alps, more that columns, architraves, cornices and universal canons, are the first to be represented in his notebook during his journey. The real interest is a sudden dialogue between artificial forms, together with nature's organic shapes and the sense of orientation they spread. Urban structures follow the impossible form of the land by refusing a horizontal development. They adapt themselves to topography, and the form of the territory acquires a new result thanks to human action, in a sort of cultural symbiosis (Weston 1995: 102). In 1926 Aalto writes: "The town on the hill...is the purest, most individual and most natural form in urban design. Above all, it has a natural beauty in that it reaches full stature when seen from the level of the human eye, that is, from ground level' (Aalto 1926: 13). Many sketches reveal the interest for this particular landscape whose primary structure is given by the shape of the land, rather than by buildings (Figure 6). The terraced cultivations have the same importance of classical Greek ruins. The architecture capable of modelling the territory, at the same time being modelled by it, is a fascination that we find in his planning experiences which would follow later on: in the Iranian Museum of Modern Art (1970) where the building placed on top of a hill abandons its formal identity to enhance that of the existing hill; in the Muurame Church project the architect forgets the evident geographical facts (a flat area) to propose again the harmonious conditions he saw in Italy, "a sleek campanile, more than twice the height of the nave, complemented the eroic arch, which itself recalls Leone Battista Alberti's Sant'Andrea in Mantua" (Reed and Frampton 1998). 
Figure 6. Alvar Aalto, Italian Trip Sketches, 1924-1948
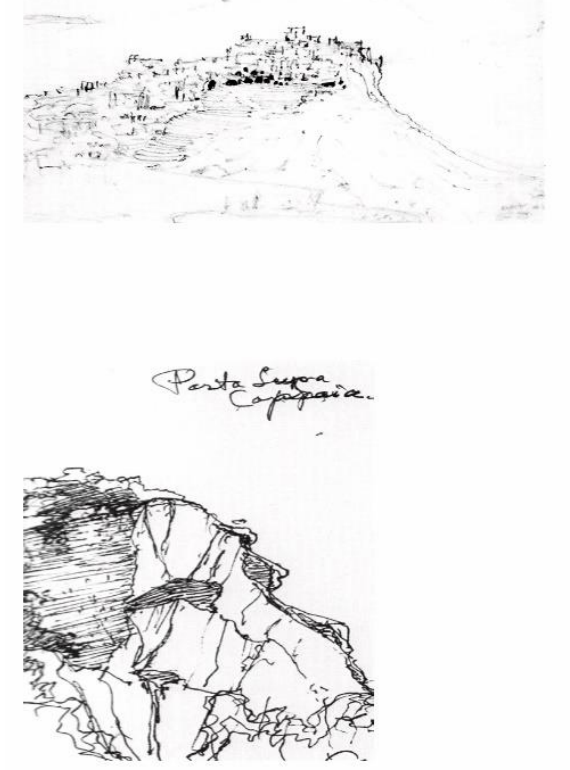

Source: Lotus International, 68, 1991.

Travelling across the Mediterranean is an occasion to investigate the relationship between human and nature, architecture and landscape. Architecture on the top of a sloped hill can represent also a human predominance towards nature, causing unease and pride.

When in Greece, during his training journey, on 7 September 1910, Le Corbusier lands in Daphne, going on a mule to Karie's and getting to the convent of Agiou Pavlou Xeropotamou. There he writes: "From the window lodged at the end of a deep splay, three times, 1 watch at dawn the light invade this endless space, while below, at the foot of the walls, the olive trees looked like tiny lichen. How painful is this inability to record on paper the impression that the patches of earth, the perpendicularity of the red rocks, the expanse of the sea have stirred in the depths of my soul, without opening to them the light of day!" (Le Corbusier 1911: 185). (Figure 7).

Figure 7. Le Corbusier. Monte Athos, Simonos Petra Monastery, 1911

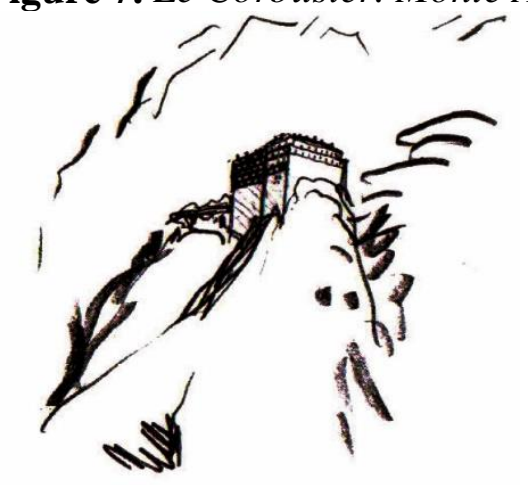

Source: Lotus International, 68, 1991. 
The same lecorbusieran dream appears in the planning process of Luigi Cosenza and Bernard Rudofsky in 1937. They propose a single family house with 22 rooms on a narrow plot 500 meters long in Naples. Villa Oro terraces work as a boat bridge dominating the waves from a 40 meter height; the building is arranged on many levels and is surrounded by a rail explicitly inspired by boats. The metric choice reinforces the abstract image of pure volumes through white plaster, in contrast with the stone podium (Figure 8). In this project the topological research prevails on type affirmations. The volumes succession, made of joints between void and masses, draws a free plan. The view towards the bay undergoes a sort of multiplication. Unexpectedly, an architecture able to keep together the rationalist rules and a potential of freedom ,with respect to rationalist rigour, takes form in a remote corner of Europe, after the travel reflections about ground, light and spontaneous life. The aggressive geographical connotation and the pleasantness of the Mediterranean climate drive the attention of planning towards the creation of open air spaces, capable of breaking up the pure volume geometry, and shaping it as if it were a handmade organism. On that Mediterranean coast a naturalistic version of Existenzminimum develops, as an attempt at using every single space, either open or closed, in every level and direction. Different functions find their place in elementary minimal volumes hosting magnolias and figs, sustained by local calcareous stone. The sequence of rooms and the service path embrace various levels and seem a very mediterranean promenade architecturale. The extreme character of the context and the many limitations coming from the difficulties met during construction become the occasion to realize a rational architecture, new and functional.

Figure 8. Luigi Cosenza, Bernard Rudofsky. Villa Oro, Posillipo, 1937

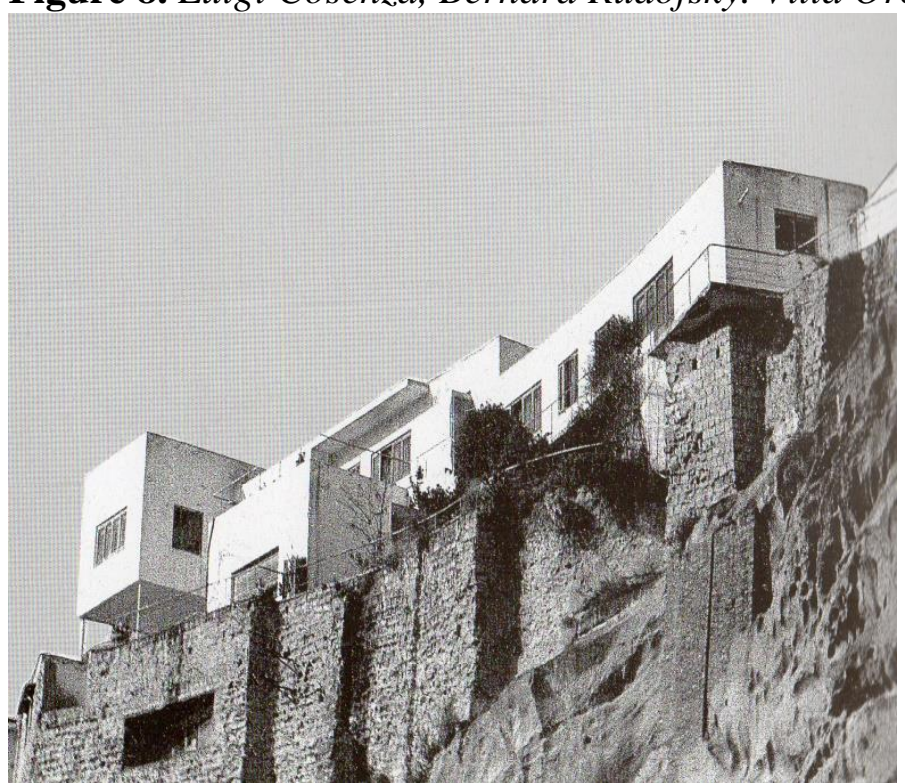

Source: Buccaro A., Mainini G., Luigi Cosenza Oggi 1905-2005, Clean Edizioni, 2006.

The relationship between soil and building in the Mediterranean continuously shows, from either an orographic or an established point of view, in the mixture of 
natural and artificial elements, as well as in the denial of this intimacy that at the same time legitimates it. Human works and landscape merge, as in Kahn's drawings, made in Greece (Figure 9): it is difficult to distinguish in the drawing what is natural and what is man-made, while the contrast between masses and voids, light and colours, is very clear.

Figure 9. Louis Kahn. Delphi, 1951
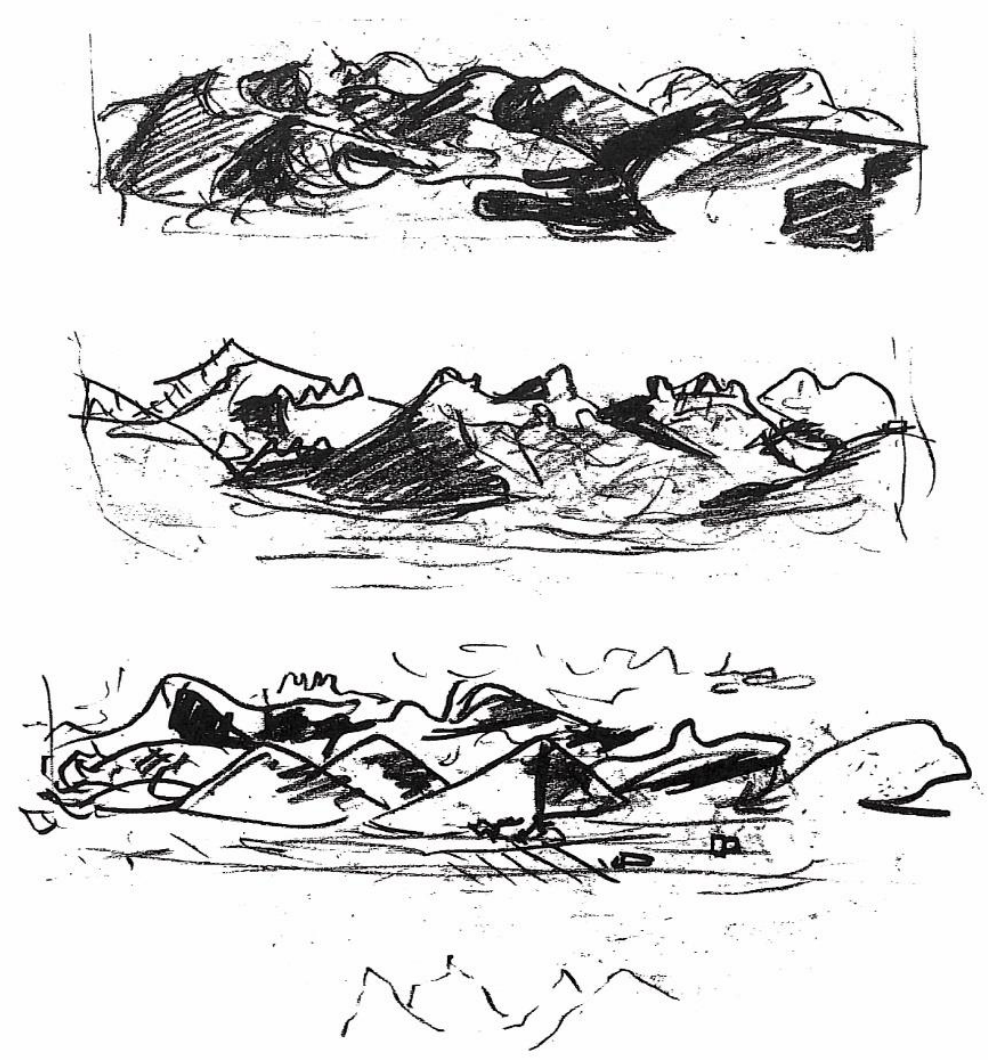

Source: Feldman E., Wurman R.S., The Notebooks And Drawings Of Louis I. Khan, The Falcon Press, Philadelphia, 1962.

\section{Space Sequences and Axiality}

The study of spontaneous architecture during Mediterranean journeys unhinges every a-priori compositional intention. Karl Friedrich Schinkel for example, after his tour between 1820 and 1830, opposes the rigid, static and axial way of planning in the text Das Architektonische Lehrbuch, dealing with tectonic and compositional rules. In the text Schinkel says there is a sort of hidden order, not very well investigated at the time, referring to the asymmetries popular architecture showed. "The order - he writes - has to be linked to the inner space function, and can be reached through the use of symmetry, that anyone can 
understand, otherwise through less evident means, that only the ones aware of primary principle can understand"1.

Geometry and harmony become elusive when they appear in minor architecture, but in modern architects the expression of that apparently ill-formed composition becomes a subject of attention. Le Corbusier suffers the same fascination in Costantinopoli, on the 19 August 1911:

"Wouldn't it take me a lifetime of labour to harness these simple and eternal forces, fraught with the uncertainty of ever attaining the proportions, unity, and clarity worthy of even a little country cottage built in accordance with the invaluable laws of an age -old tradition?" (Le Corbusier 1911: 177).

On this subject, the work of Omada Filòn is very important. This group of Greek artists, which included painters, poets, sculptors, journalists and architects, travel in 1925-1926 around some islands nearby Athens. Aegina Island among them plays a fundamental role, as this is the place where Omada members go around with students to create a great database by taking sketches, documents and objects. They investigate every form of popular art: houses, stairs, terraces, decorations and furniture. The aim is to read Greek landscape and architecture like a privileged place for any sort of artistic inspiration. The group seems very interested in the series of cubic volumes composed in one building, all linked by two crucial factors: life and sensitivity. They study above all a small house on Aegina Island, built without rules by the owner, a peasant named Rhodakis. According to Dimitris Pikionis (Piraeus 1887 - Athens 1968) the L shaped house could be an answer to the modernist «machine a habiter» (Ferro 2004). Rodakis House is composed of a main building, with big rooms for many uses, that is to say living or keeping animals. The only separate volume is the kitchen, placed inside the court. The Omada Filon's description of the house seems to be the easiest way to tell what a Greek 'landscape' is: past experiences, but also needs, traditions and religion. The interpretation of the threshold defines the creative process connecting the building to nature; its limits are not well defined. The threshold can't be clearly identified as it develops along the path between the fence and the entrance to the house.

The house plan lets us approach the building thanks to a series of progressive movements, by taking the visitor among more and more compressed spaces, in a spontaneous but clear rhythm. This entire path is in the open air, developed between the white and tall fence and the independent volumes of the building; it takes from the public entrance to the inner intimate patio, overlooked by the whole of function. This is the place where life develops. In this small Aegina house, we can recognize the anticipation of an architecture that is understood by being walked in and that, in the process, succeeds in giving the visitor an endless number of perspectives.

On the other side of the Mediterranean basin, in Spain, another group of artists called GATEPAC is founded in 1928 and from 1931 it promotes a survey

\footnotetext{
${ }^{1}$ The book was never published, it is cited in J. Francois Lejeune, M. Sabatino, Modern Architecture and the Mediterranean, Routledge, Oxon, 2010, page XVII.
} 
campaign in order to underline formal traditions of popular Spanish architecture. The Catalan architect Luis Sert (Barcelona, 1902 - 1983), one of the co-founders of GATEPAC, after many journeys writes:

"Ni el alzado, ni la planta responden nunca, en la arquitectura popular, a una composiciòn premeditada. El conjunto no es otra cosa que una sencilla justaposiciòn de cuerpos simples con el mayor sentido racional. Primero, es un pequeño añadido con uno o dos dormitorios màs, luego, un porche, después, un establo que hay que ampliar, etc... (...) $Y$ es curioso observar como estas construcciones han servido de modelo a una arquitectura académico popular, artificiosa, que ha encontrado en las manifestaciones populares una fuente de inspiración de donde sacar sus inagotables formas. Faltos de una base moral - puesto que en arquitectura deberia existir una base moral - estos arquitectos han partido del aspecto pintoresco de las construcciones rurales, destruyendo incoscientemente los principios básicos en que estás se apoyan" (Lluis Sert, 1935).

Starting from the Mediterranean, in these years, the attention of architects is directed towards the comprehension of a wisdom in the planning process that architects believe they are about to forget. When in front of the Acropolis, Eric Mendelsohn (Allenstein, 1887 - San Francisco, 1953) is not shocked by the architectural bigness or by proportions, "he was especially impressed by the way in which the approach is so calculated and integrated with the entire complex" 2 . Architects are looking in the ancient heritage for new rules to do architecture. Some years later the Acropolis fascination will come back in Weizmann House (1950), where Mendelsohn breaks the symmetry of the court scheme by introducing dynamic data into the composition. In Mendelsohn's project, to get to the main entrance, you need to discover every single side, and consider the plastic feature of the house while entering the inner space.

The dynamic development of the composition based on the more or less regular succession of different points of view, becomes a leitmotive to those who travelled to the banks of myth. It's a new compositional grammar that comes from the observation of the Mediterranean vernacular architecture.

"Le Corbusier had devoted exceptional attention to Pompeii in his travels: he annotated his Baedeker, kept a list of houses he had examined, and ornate numerous sketches and watercolours on the site. Moreover, he must have been familiar with the reconstructions of Roman atrium-houses as they appeared in the widely published book by August Mau. (...) The facade-like treatment of interior elevations, the open stairs ascending to internal balconies, and the gathering of adjoining spaces around an open core were not totally new to architecture. But the Roman houses Le Corbusier examined in Pompeii combined familiar elements in a decidedly uncommon manner. The axial deployment of the atrium-house afforded a "promenade» from the street to the rear garden across hallways and atria. The sequence of highly differentiated cubicles and the subtle shifts in their alignment are especially remarkable in the Pompeian House of the Tragic Poet. The judicious displacement of emphasis from the central axis recalls immediately the shift of Le

\footnotetext{
${ }^{2}$ S. King, Interview with Mrs. Mendelsohn, quoted in J. Francois Lejeune, M. Sabatino, Modern Architecture and the Mediterranean, p. 188.
} 
Corbusier's little balcony from its originally central position on the La Roche gallery to the extreme left side, as well as the counterbalance between the extrusion of the living room bay in the Jeanneret house and the recessed hall-bay of the La Roche house. The centric entrance to the atrium of the Pompeian house and the lateral displacement of the right-hand walls in front and back of the atrium-corridor imply a comparable relation to the guiding axis of the house in Auteuil" (Forster 1979).

In Villa La Roche (1923) the entrance is placed in a key position, and takes guests from one floor to the other through stairs, as an atrium made of many floors (Figure 10). Canonical axes are not recognizable anymore, and the main space gives a sort of dismay. The Pompei Forum plan, with its many hierarchical axes, provokes a sort of joy of the spirit, even if it would be refused by the Ecole des Beaux-Art. Le Corbusier deduces in his Towards an architecture: "the axis is not dry theory", it ties together the principal volumes which are nearly inscribed and differentiated one from the other; we don't have to put all the architecture on axis, the result would be similar to that of many people speaking all at once. Order withdraws from symmetry, looking for the axis hierarchy, which will later become a hierarchy of aims and a classification of intentions.

\title{
The Economy of Expressive Means
}

Mediterranean traveler architects refused at the same time any sort of historicism, together with the use of predefined styles and eclecticism. Their revolution is made of an out-of-time attitude towards monuments: the historic building is looked at in its most essential form, the square as a sublime synthesis of space and functions. All architects put into practice many forms of abstraction. Every object unchanged over centuries becomes different, as if seen under a different point of view: dovecot towers become vertical episodes on persisting horizontal dynamics, loggias become pure subtractions, external stairs an addition to the original volume. In 1929 the Italian architect Plinio Marconi (Verona, 1893 - Roma, 1974), after many trips to the Italian Tyrrhenian small islands underlines this sort of primitiveness arising in the new architectural sensitivity.

\begin{abstract}
"Lo studio e l'attenta considerazione di queste fabbriche elementari -si riferisce alle architetture minime del mediterraneo- ci giovano invece sotto altri punti di vista più larghi. In primo luogo possiamo assorbire da esse, rimanendo nel nostro piano di uomini attuali, quel senso di aderenza alla costruzione che le ispira nel loro: essere nell'ambito dei nostri mezzi così costruttivi e semplici come il contadino di Capri lo è stato coi propri. Impariamo ancora che, specie nelle piccole architetture, quando il senso del volume, delle superfici e dei profili è nettamente formulato e artisticamente potenziato, quando il colore degli impasti è ben scelto, non è necessario aggiungere membrature non esistenti per fare una cosa bella: ciò è importante ai fini delle tendenze moderne" (Marconi 1929).
\end{abstract}

In Italy, the article by Marconi came out with many other on similar topics, dealing with spontaneous construction in the Mediterranean area: P. Egidi (Appunti su alcune costruzioni di Siria e Palestina) 1921, E. Cerio (L'architettura 
minima nella contrada delle sirene) 1922, A. Maiuri (Architettura paesana a Rodi-La casa di Lindo) 1924, G. Capponi (Motivi di architettura ischiana) 1927, R. Pane (Tipi di architettura rustica in Napoli e Campi Flegrei) 1928.

In Lesson from Rome (1928) Le Corbusier describes the buildings he had seen during his journey, considering the pure volumes as the very starting point.

"The light caresses the pure forms: it renders. The simple volumes unfold vast surfaces that express themselves with a characteristic variety depending on their being domes, barrel vaults, cylinders, rectangular prisms, or pyramids. The surface decoration (openings) is of the same geometric class. The Pantheon, the Colosseum, the aqueducts, the Pyramid of Cestius, triumphal arches, the Basilica of Costantine, the Bath of Caracalla. No verbosity; ordonnance, a single idea, boldness and unity of construction, the use of elementary forms. Sound morality. Let us retain from the Romans the bricks and Roman cement and travertine stone, and let's sell roman marble to the millionaires" (Le Corbusier 1928: 200).

As Omada Filon in Greece and the GATEPAC in Spain, the architect Giuseppe Pagano travels Italy to document the vernacular tradition in architecture. He takes photos and planimetric sketches of the main typologies of rural building, underlining the tectonic and material simplicity of the vernacular in opposition to its picturesque simulation. For him, this constituted a potentially new impetus in the modernist, rationalist design that could lay claim to the traditional values grounded in Italy's agrarian past, and ultimately cast it as a source for contemporary functionalist practice (Sabatino 2008: 350).

"Questi elementi, adesso propri del movimento moderno provengono dalla nostra cultura mediterranea e si sono conservati in tutti i tempi. Il movimento moderno li ha riscoperti. Questa architettura limpida è il linguaggio autoctono della civiltà mediterranea, linguaggio che parla innanzitutto con spregiudicato raziocinio e che, dallo stesso ragionamento funzionale trae motivo di lirica espressione artistica. Questa maniera di esprimersi è assai prossima, moralmente e quasi anche formalmente, al credo degli architetti contemporanei. (...) questa orgogliosa modestia tanto analoga al sentimento dell'architettura contemporanea e per far ricordare quanto sia necessaria la coerenza con il tempo, col clima, con la tecnica e con la vita economica per fare onesto lavoro architettonico" (Pagano 1935).

Vernacular architecture examples, that had received romantic attention in the past century, become masters of building sincerity. The essentiality of a building, born spontaneously and with minimal resources, becomes the aim of modern times.

"Da queste architetture mediterranee anonime, da queste architetture naturali, nate d'istinto, come le agavi giganti e i fichi d'india che le circondano, discende per noi una lezione, ancora oggi valida. Per noi, anonimi costruttori individualisti, figli del progresso meccanico, della tecnica e della cultura, che sapendo tante, troppe cose, ne abbiamo dimenticate tante altre. Lezione di morale e di logica (semplicità, sincerità, modestia, umiltà, aderenza alle necessità, rinuncia al superfluo, adeguamento alla scala umana, adattamento alle determinanti locali e ambientali), lezione di vita (vasto impiego di elementi "intermediari" tra il vivere al chiuso e il 
vivere all'aperto: loggie, terrazzi, portici, pergole, patii, orti murati, ecc..), lezione di stile (antidecorativismo, amore delle pareti liscie e delle soluzioni plastiche elementari, collocazione e inquadramento dell'edificio nel paesaggio)" (Figini 1950).

The adherence to needs, together with the discarding of the superfluous and the attention to human scale, become a key to read contemporary reality. It is a Mediterranean thought. Mediterranean architecture is seen as made of masses and rationality; it is mainly based on two elementary operations: addition and subtraction. The main feature thought is that material modelling very often comes from functional needs: loggias, terraces, porticoes, patios, enclosed orchards. Stairs are elements to pass by, to be built outside the building. Stairs and loggias are taken out from the main building then, and porticos and pergolas are added, never leaving the original form to itself.

\section{The Outdoor Room}

One of the most studied themes by architects in the Mediterranean is the mystery inside the enclosed walls, so well expressed in the introvert character of buildings. Life developing in the outdoor domestic spaces charms Le Corbusier during his Voyage d'Orient: the enclosures break the relationships with the public realm, only to reveal its heart and liveliness once the surprised ranger trespasses.

"In Bursa, in Asia Minor, at the Green Mosque, you enter through a small doorway to human scale; a very small vestibule works on you the change of scale that's necessary to appreciate, after the dimensions of the street and the place you've just come from, the dimensions that are meant to impress you" (Le Corbusier 1928).

During the architects' trips, the patio is rediscovered not only as an element capable of generating a specific climate in its interior, but also as a new, smaller world where human scale lets anyone sit down and enjoy the fresh air during summer time.

What really charms architects, above all Le Corbusier, is the form of discretion typical of the Mediterranean area: urban enclosures, traditional musharabie, women veils.

Now it seems to me they (the girls in Istambul) are ravishing despite and also because of that second skirt flung over their heads that makes an impenetrable veil. You will find real coquettes underneath. I bet you, you old bony fakir (Klip), that almost all of them are young, adorable, with ivory cheeks a little full and with the innocent eyes of gazelles - delicious! After all, these veils conceal a penetrable mystery. It seems to me that there are thousands of them who wish to display their beauty, and devilish as they are, they know how to get around all the codes. They have a touch of genius... (Le Corbusier 1911).

After twenty years, Le Corbusier is again travelling toward the south Mediterranean area. In 1931 he goes to Spain, Morocco and Algeria. When back 
from Algeria, Le Corbusier describes the impressive contrast between M'Zab city centre's architectural bigness and the simple flow of its daily life in patios. The most striking element to him was the strong, apparently impenetrable external walls. They define a system of properly lighted and well working inner spaces.

"The houses are completely closed off from the alleys. But, inside, opening onto the abundance of fertile stands of trees, is completely equipped, perfect, efficient, eminently functional, on a human scale" (Le Corbusier 1931).

In 1952, the Mexican architect Luis Barragan (Guadalajara, 1902- Mexico City, 1988) was also very influenced by the observation of local southern Mediterranean traditions.

"Un viaje que hice al África ha sido el que más me ha impresionado en mi vida; ví las construcciones que se llaman casbah, en el norte del desierto del Sahara. Eso es lo que encontré plásticamente más ligato al paisaje, más ligado a la gente que lo vive, a su ropa, al ambiente, inclusive más ligado a sus propias danzas, a su familia; ahi encontré la integración perfecta de la religión con todo el ambiente en que se vive con las cosas fisicas que se tocan" (Barragán 1984).

The central space surrounded by thick walls and opened on top, seems to be very important for the development of the sort of life that charmed travellers. Patio becomes a symbol of "joy". Once back to México Barragán deals with the topic of housing and, thanks to his travel experience, the architect opposes Guadalajara (his native city) model of growth based on chalets, single family dwellings. The patio acquires a symbolic value, as it becomes the symbol of family unity: the «sense of family» and Mediterraneism become the fundamental mean to get his clients' favour, to conjugate their traditions and their intercontinental desires. In the house he planned for his friend Efrain Gonzalez Luna in 1929, for example, privacy is underlined by using filters such as pergolas, fences and jalousies. The in-out relationship is always exclusive: a long corridor reaches the hearth of the house, the living room has tall windows which let the light in but don't allow people to look out, to underline its intimate and domestic character.

Patio becomes a model to be exported. During his stay at Harvard University, Lluis Sert will also work a lot on it:

"Patio, intriguing word, readily conjures visions in one's mind of sunny skies, blue water, palm trees and balmy breezes. For surely the association between these climatic and geographic qualities and the walled residential yard is inevitable to the average American observer; particularly if he is experienced in any way with the admirable architectural traditions of the Mediterranean area. To the more engrossed observer there is less a geographic limitation since the patio is frequently found in Central and Eastern Asia, Africa, Central and South America and (I am sure) elsewhere. The Mediterranean connotation, however, may be rather formly established in the Western mind' (Sert, c. 1950).

The Patio becomes an «outdoor» room, where all domestic functions can be held. To this extent, in the second half of the 20th century, the patio model 
gains popularity as it represents one of the most valid answers to the architects' interest towards flexibility. The open space can host different functions along the day. The activities change depending on a door left open, or on the possibility of expanding to a room of the house. Open air life, enclosed on its four edges, becomes a universal inspiration; it is confirmed, again, by Le Corbusier project of elevation of Beistegui's flat in Paris. In this case the terrace will be unmercifully surrounded by white walls, ignoring the wonderful view towards Tour Eiffel, leaving only the top part visible.

The outdoor-room is used in very different ways by traveller architects: the big space for the audience of Skandia theatre by Asplund, for example, is opened towards the blue sky, inspired by the one he had experienced in 1913 in Tunis: "Above our heads a sky clear and deep the like of which I have never seen, such a tone in the colour that I constantly imagining the sky as a vast blue-painted dome. All the buildings white, the streets a dazzling chalky white, making the eyes ache and feel like narrow slits" (Gunnar 1913).

\section{Sitting in the Sun as Long as it is willing to shine}

Thanks to the many journeys, in the first part of the XX century a Mediterranean modus vivendi begins to spread in the entire world.

After having lived two years in Capri, Bernard Rudofsky (Suchdol nad Odrou, 1905 - New York, 1988) suggests, in an article published on Domus in 1938 , to go back to the Mediterranean "sapienti usanze senza tempo", that modern culture seems to have forgotten: "il sentirsi vellicare la pianta dei piedi dalla sabbia, da erba ben rasata, da un marmo levigator" (Rudofsky 1938). According to Rudofsky, we need to abolish the act of "lavarsi, barbaramente ridottosi ad una piccola vasca di acqua stantia, ritornare ad avere una stanza dedicata all'uopo", where a lower floor can host water and where the sun can go in during the day. " $E$ la seduta... ritorni ad essere un cline".

Goethe had already told in his Viaggio in Italia (1787) about the sensual and slow rhythm of life of Mediterranean people.

By the time we reached the outskirts of Naples the sky was completely cloudless, and now we are really in another country. The houses with their flat roofs indicate another climate, though I dare say they are not so comfortable inside. Everybody is out in the streets and sitting in the sun as long as it is willing to shine. The Neapolitan firmly believes that he lives in Paradise and takes a very dismal view of northern countries. Sempre neve, case di legno. gran ignoranza, ma denari assai - that is how he pictures our lives. For the edification of all northerners, this means: 'Snow all the year round, wooden houses, great ignorance, but lots of money.' Naples proclaims herself from the first as gay, free and alive. A numberless host is running hither and thither in all directions, the King is away hunting, the Queen is pregnant and all is right with the world" (Goethe 1786-1788: 184).

More than a century later, the German architect Mendelsohn will be a victim of the same fascination in Corsica: "The Mediterranean contemplates and creates; the North winds itself up and labours. The Mediterranean lives; the North defends 
itself. [...]Here one can grow old without work...No comforts, just sun, no desires, just being" (Mendelsohn 1931).

According to the traveller architects, the way in which Mediterranean people live has a consequence in their cities' development. The poetry of the Mediterranean lifestyle becomes a reflection on all open spaces: light, the harmony of the orographic relationship with nature, the concatenation of spaces, visual sequences. Architects steadily look at the use of the public realm, of roads and squares. In the Mediterranean area, each city-system has its own centre, or its medina, whose form comes from the tangle of paths, from the buildings knotting, from past and present merging. Moreover, climate and public space compression helps their use all day long. Architects are fascinated by a public realm, intended as a natural prosecution of domestic space, where one can bring chairs and furniture during summer evenings. They represent the Mediterranean modus vivendi in a succession of sketches and photographs portraying men, women, children and animals that live the most unusual street corners. In Naples Gunnar Asplund writes: "The streets of Naples filled with urchins, so that one can hardly get along, confetti throwing and gay life. In the evening from the boat in the harbour, with the reddish lights reflected in the deep blue of the sea and the moon shining for all it is worth, we threw coins on the quay for the lads to fight over - and all around were Neapolitans singing their pensive love ballads to the strains of the mandolin and the violin, as our boat cast off and we sailed away. A calm sea and a lovely moonlight passage".

In Palermo: "This is indeed the Orient, strong in colours and great in indolence, but a life of movement such as I have never befor seen... Boys are splashing and bathing in the blue waters, the harbour is filled with masts and gaily-coloured boats with lug sails - and then Castellamare, time-worn, red of hue and with a loggia. The plants clinging to the church walls are in bloom, the sun is burning hot, the light is dazzling white". In Siracusa: "We drank coffee and Strega at a little cafè on the cathedral square in the midst of the crowd and the charming and rather impudent Italian carnival figures. Offered cigarettes to ruffians, played ball with children, let people throw confetti in our mouths, made eyes at darkeyed Sicilian beauties chinking their castanet, gathered quite a crowd around us". In Tunis: "Tunis, this is the most amusing I have come across in the 28 years of my existence! Not as a town of art, but for its outstanding gay and lively character. (Of course, I said something much the same about Palermo, but that has faded away now!)". Asplund's is interested in every sort of open air, daily life expression: the anonymous building; the life in the square; the proportions of a public washtub in Cefalù; the Venetian palace's light reflections and their image mirrored in the canal; Naples's carnival; the main road of small Sicilian towns, the "lampare" taking the sea. In his notes it seems that the coastal inhabitant's movements and customs are able to describe places. The way people live a space is what creates its value. The way they move around gives a measure of it and underlines its human scale. During his Italian journey, Asplund never takes photos without portraying people, showing that architecture doesn't exist without its inhabitants, it doesn't exist without the inhabitants' and observer's 
feelings (Mansilla 2008). Architecture and urban scenes are analysed by understanding social principles and community life.

Figure 10. Groundfloor of the House of the Tragic Poet; Groundfloor of Maison La Roche; Le Corbusier. Sketch of the Groundfloor of the House of the Tragic Poet
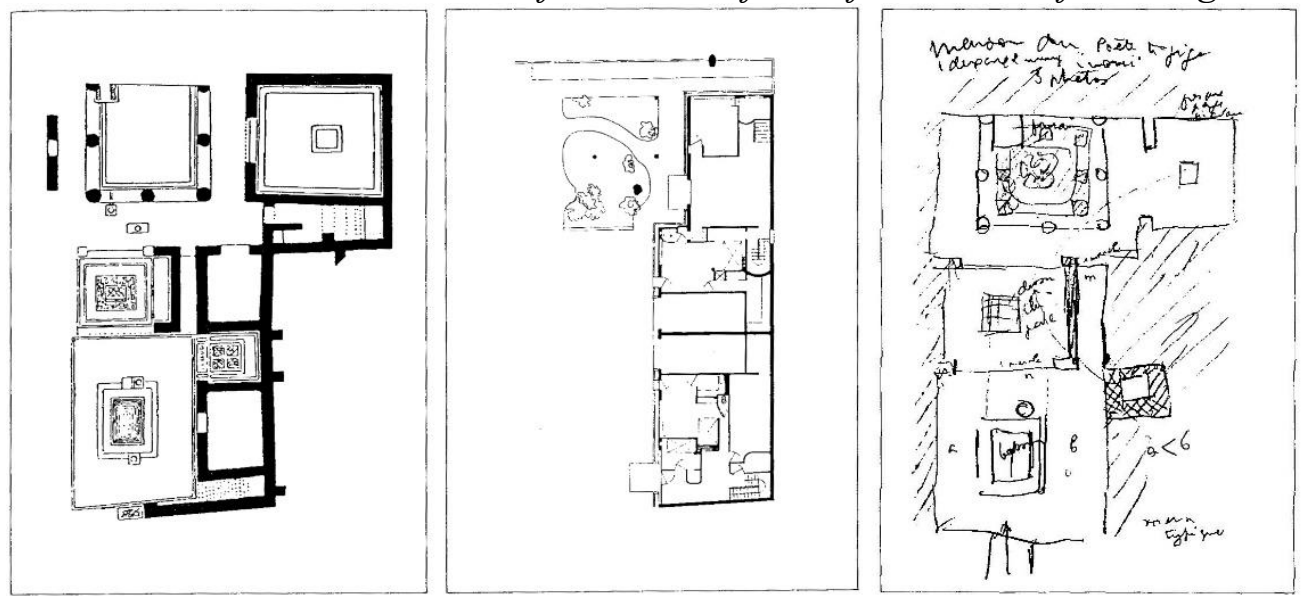

Source: Forster 1979.

Figure 11. Alvar Aalto, Venice, 1924

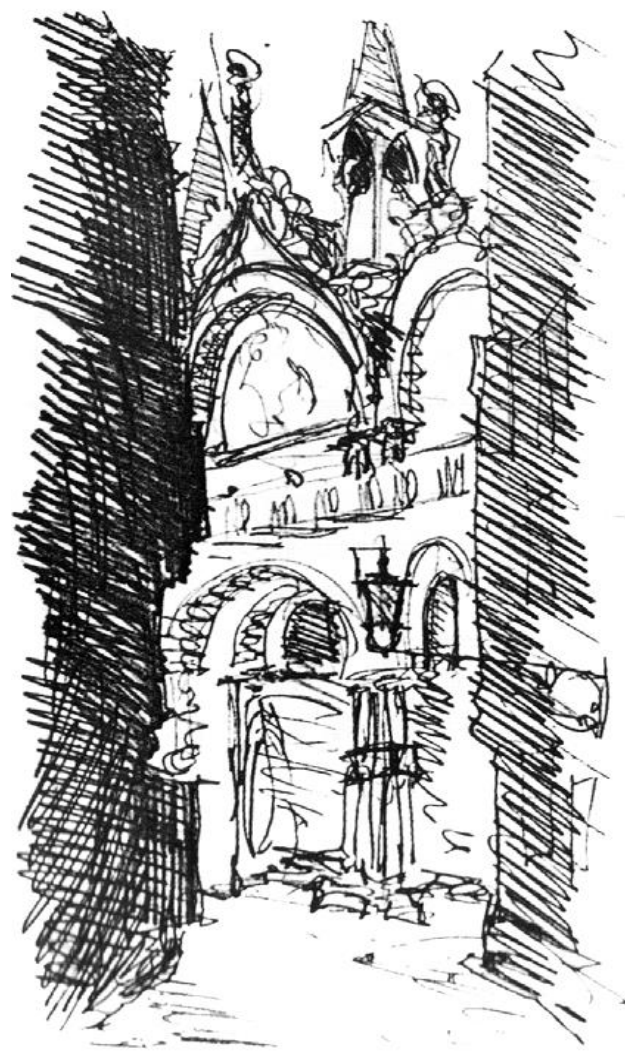

Source: Lotus International, 68, 1991. 
Figure 12. Louis Kahn, Florence, 1950

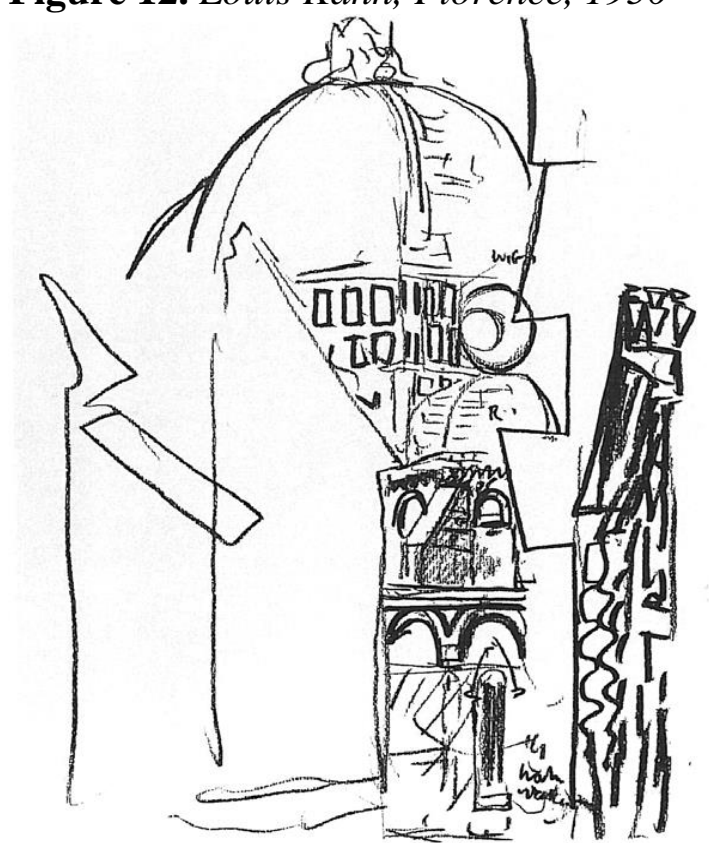

Source: Feldman E., Wurman R.S., The Notebooks And Drawings Of Louis I. Khan, The Falcon Press, Philadelphia, 1962.

Aalto, Kahn, and Alvaro Siza also try to underline these spaces' proportions through their drawings, as if the street narrowness was the main reason for its use; the more it arrived to a greater space, like a square, a "campo", or a widening, the better. Volumes define the rest, together with the way they lay on the ground. Inhabitants and light are the two elements defining the space of the city. Voids become stronger thanks to the dimensional contrast with the urban fabric compression, made of shadows and narrow streets. The relationship between mass and void leads the game and draws big spaces, the position and rotation of volumes give to their negative a better value. The rest is due to light, as if light could not only describe a space, but also define its real proper uses. What happens in urban voids is very important for travellers to understand the unwritten rules of a shifty city, where orthogonal layouts disappear to host ever-changing three-dimensional paths. The key of the rediscovered Mediterranean architecture seems to be in the relationships, in the in-between and in its very measures (Figures 10-11-12).

\section{Conclusions: Crossbreeding in Contemporary Architecture}

The Mediterranean is a complex field that eludes its geographical borders and asserts itself as a cultural landscape through the power of image, from which form and proportions derive. For this reason, the Mediterranean defines a sense of belonging beyond personal data and places of residence; it is based on the perception of landscape and on the capacity of recognizing certain flavours, smells, perfumes, materials, and sounds. 
Many contemporary architects use the topics I have addressed in this paper, a kind of citation aware of the Mediterranean as a landscape translated by human thought. Portuguese architecture discovers the Mediterranean thanks to Aalto, through the figure of Alvaro Siza; traditional topics come back in the basin's contemporary architecture, filtered by strangers and ex-travellers, as for example Barragan, to be later on contaminated and enriched even more. The Mediterranean flows in the veins of contemporary architecture.

\section{References}

VvAa (1991) L'occhio dell'architetto. In "Lotus", 68.

Aalto A (1926) Fragment. In G Schildt (1986). Alvar Aalto: The Decisive Years. New York: Rizzoli.

Asplund G (1913) Notes. In VvAa (1981) Gunnar Asplund Architect 1885-1940: Plans, Sketches and Photographs. Stockholm: Byggforlaget.

Le Corbusier (1965) Fragment. VvAa (1987) Le Corbusier Et La Méditerranée. Marseille: Editions Parenthèses.

Barragan L (1984) Fragment. Ramìrez Ugarte A (1984) Los jardines de Luis Barragan. Mexico en el Arte, 5. Mexico: Nueva Epoca.

Braudel F (1990) La Méditerranée et le monde méditerranée à l'époque de Philippe II. Paris: Armand Colin.

Buccaro A, Mainini G (2006) Luigi Cosenza Oggi 1905/2005. Napoli: Clean Edizioni.

Capitel A (2002) José Luis Sert. Valladolid: Universidad de Valladolid.

Capponi G (1927) Motivi di Architettura Ischiana. Architettura e arti decorative, 11. Milano: Bestetti e Tumminelli.

Cerio E (1922) L'architettura Minima Nella Contrada Delle Sirene. Architettura e Arti Decorative, 4. Milano: Bestetti e Tumminelli.

Egidi P (1921) Appunti su Alcune Costruzioni di Siria e Palestina. Architettura e arti decorative, 5. Milano: Bestetti e Tumminelli.

Feldman E, Wurman RS (1962) The Notebooks and Drawings of Louis I. Kahn. Philadelphia: The Falcon Press.

Ferro L (2004) In Grecia, archeologia architettura paesaggio. Boves: Araba Fenice Edizioni.

Figini L (1950) Architettura Naturale a Ibiza. Comunità, 8. Ivrea: Fondazione Adriano Olivetti.

Forster KW (1979) Antiquity and Modernity in the La Roche-Jeanneret- House of 1923. Opposition, 15/16. San Francisco: The Institute for Architecture and Urban Studies.

Frampton K, Reed P (1998) Alvar Aalto: Between Humanism and Materialism. New York: Museum of Modern Art.

Goethe JW (1816) Italian Journey. Ed. Ingl. (1992). London: Penguin books.

Le Corbusier (1911) Fragment. I Žaknić (1987) Le Corbusier, Journey to the East. London: MIT Press.

Le Corbusier (1928) Toward an Architecture. Ried: Getty publication.

Le Corbusier (1931) Fragment. Plans 8. Paris: Revue Plan.

Lejeune JF, Sabatino M (2010) Modern Architecture and the Mediterranean. Oxon: Routledge.

Maiuri A (1924) Architettura Paesana a Rodi-La Casa di Lindo. Architettura e Arti Decorative, 9. Milano: Bestetti e Tumminelli. 
Mansilla LM (2008) Apuntes de viaje al interior del tiempo. Barcelona: Editorial Gustavo Gili.

Marconi P (1929) Architetture Minime Mediterranee e Architettura Moderna. Architettura ed Arti Decorative, I. Milano: Bestetti e Tumminelli.

Martinez AR (1996) 1902-1988 Luis Barragan. Milano: Electa.

Mendelsohn E (1931) Letter to his wife. Lejeune JF, Sabatino M (2010) Modern Architecture and the Mediterranean. Oxon: Routledge.

Kahn LI (1951) Fragment. McCarter R (2005). Louis I. Kahn. London: Phaidon.

Pagano G (1935) Documenti di Architettura rurale. Casabella, 8, 95. Torino: Arnoldo Mondadori Editore.

Pane R (1928) Tipi di Architettura Rustica in Napoli e Campi Flegrei. Architettura e Arti Decorative, 12. Milano: Bestetti e Tumminelli.

Pollini G (1933) Corsivo n. 40. Quadrante, 5. Milano: Modiano.

Rudofsky B (1938) Non ci vuole un nuovo modo di costruire ci vuole un nuovo modo di vivere. Domus, 16. Rozzano: Editoriale Domus.

Sabatino M (2008) Ghosts and Barbarians: The Vernacular in Italian Modern Architecture and Design. Journal of Design History, 21, 4.

Schildt G (1986) Alvar Aalto: the decisive years. New York: Rizzoli.

Sert L (1935) Fragment. Pizza A (1997) Sert y el Mediterraneo. Barcelona: Col-legi d'arquitectes de Catalunya.

Sert L (1950) Fragment. Pizza A (1997) Sert y el Mediterraneo. Barcelona: Col-legi d'arquitectes de Catalunya.

Weston R (1995) Alvar Aalto. London: Phaidon Press. 



\title{
Religious Terminology as Consolidating and Mediating between Ethno-National Groups: A Case-Study of the Arab Communists in Mandatory Palestine and in Israel (1925-1967)
}

\author{
By Maysoun Ershead Shehade*
}

This paper uses a qualitative text analysis to examine the use of religious terminology (RT) as a tool for national engineering and achieving of political gains, by the Arab leadership and activists of the Communist Party in mandatory Palestine and thereafter in the State of Israel. Based on the framework posited by Antonio Gramsci, the paper examines how a group of "organic" intellectuals used religion as a tool for inserting ideas and for influencing the public arena, and presents a typology examining the changing circumstances that dictate the modes and purposes of RT usage. The main conclusion from this study indicates that $R T$ was used in order to achieve legitimacy, presence, and dominance in the Palestinian and Arab ethno-national space, the Arab-Jewish joint space, and the cosmopolitan space identified with communism. RT seems to serve as a consolidating and mediating tool in and between the three spaces.

Keywords: Religious Terminology (RT),Communist Palestinian Arabs in Israel, National Engineering Tool, Marxism and Religion, Organic Intellectuals.

\section{Introduction}

In general, it can be said that the connection between religion, communism, and nationalism was always present in the Arab world. Most communist political activists in the Arab states have their roots deeply entrenched in religious culture. The leaders of the Arab left wing are mostly Muslim believers, and most leaders who were defined as socialists demonstrated loyalty to socialism that draws its ideas from Islam. For this reason, they tried to formulate a certain type of "Arab socialism", which integrated Marxist ideas and Islamic Arab National foundations (Ginat 2008). Not only Muslim, but also Jewish and Christian political leaders and activists opened the door to communism, primarily because they found it a practical way of implementing the idea of social justice, idea concept that is well anchored in religious tenets (Froese 2004, 2005, Ginat 1996).

The Communist parties in Palestine, Egypt, Syria, Lebanon, and others were founded only after these countries transitioned from Ottoman rule, which lasted about 400 years, to the British and French Mandates (in 1918, following the Sykes-Picot agreement) and soon after gained independence. Although the Communist parties in Iraq and Sudan were the largest Arab parties in their respective countries, neither they nor other Communist parties within Arab states managed to maintain power. It seems that the main reason for the failure of the Arab Communist parties to achieve political power was their disability to link

"PhD Candidate, Department of Political Science, Bar Ilan University, Israel. 
religion and communism by constructing a local doctrine adapted to the national, social, class, and especially cultural circumstances of the region (Abu Khalil 2009).

Religious terminology (RT) was used by Arab communists as a tool, with which to influence the masses. Even if the goal of RT users is attaining political and social gains, there is no doubt that they do so when motivated by the system of religious beliefs from which they emerged (McClelland 1966, Wright 1978, Baldwin 1989). Use of RT is employed in the knowledge that its power lies in bearing stable, unchallengeable, "Divine" content, and that it has enormous ability, more than any other instrument, to strike emotional and sentimental chords (Appleby 2012). Nonetheless, the use of RT by politicians is not something that is utilized freely and with no restrictions. It has its own rules and limits: (a) Use of RT might become a "double-edged sword" against users; leaders who rely on religious legitimacy or who utilize RT are more exposed to criticism directed at them by other actors who try to undermine their religious legitimacy or reply with a counter-religious message that could weaken their position; (b) A discourse that includes RT is only effective among those with similar religious beliefs. When the religious beliefs differ, the legitimacy and RT lose their effectiveness; (c) The RT of politicians with a religious, moral, and pious reputation produce more benefits (positively effects) than those of politicians who lack such reputation; (d) RT do not hold equal effect; in other words, not every use of RT is beneficial; the impact of RT on the political opinions of community members is limited and affiliated with the speaker's personality and with the importance and content of the RT use (Fox 2018, Fox and Sandler 2004).

This paper examines the motives and purposes of using Religious terminology (RT) by Arab communists in Mandatory Palestine and later in the State of Israel. The Palestinian Communist Party underwent many upheavals during the period of the British Mandate over Palestine; over this period, it was alternately a Jewish mono-national party; a bi-national Arab and Jewish party; separated into two mono-national parties, one Arab and one Jewish; and after the establishment of the State of Israel, unified once again as a binational party. The paper will try to answer the following questions:

a) Under which circumstances could the Arab communists in Mandatory Palestine and in the State of Israel use RT?

b) For what purpose was RT used by the Arab communists in Mandatory Palestine and in the State of Israel?

c) How could the Arab communists in Mandatory Palestine and in the State of Israel use RT when the ideology they preached was stained by atheism?

The following section will present a review linking religion and the Marxist approach, and then a historical path dependent review of the Palestinian Communist Party during the British Mandate and after the establishment of the State of Israel. 


\section{Literature Review}

\section{The Marxist Approach and Religion}

Even before the publication of the Communist Manifesto, Marx succeeded in implanting an ambivalent display regarding the role of religion, stating that: "Religious suffering is, at one and the same time, the expression of real suffering and a protest against real suffering."

In his essays on Hegel's philosophy (1844), and probably influenced by his "teacher" von Feuerbach, Marx introduced a not-truly Marxist viewpoint, in fact a dialectic leftist neo-Hegelian viewpoint, that ambivalently saw in religion alienation, acceptance, and legitimization of the existing conditions, and at the same time a protest against those conditions.

Aside from this ambivalent reference to religion, Marx seldom wrote about religion, and his writings on this subject were published in his early years, the Marxist view towards religion as a social reality became clear. Religion was presented as one of the many forms of ideology - the spiritual production of any people, the conceptual production and of representations of consciousness, which necessarily depend on the production of materials and of parallel social relationships.

Despite the fact that Engels was a materialist, an atheist, and an uncompromising enemy of religion, he showed great interest in religious phenomena and in their historical role. Like Marx, he grasped the ambivalent role of religion, but added and provided an expanded analysis of the relationship between religious representations and the class struggle. It is well-known that in "Ludwig Feuerbach and the End of Classical German Philosophy" (Engels 1886: 366367), Engels dealt with the question of whether God created the world or has the world been in existence forever. He concluded that the answers given by philosophers to this question split them into two great camps. Those who assert the primacy of spirit over nature comprise the idealist camp. The others, who regard nature as primary, belong to the various schools of materialism. Engels, from a Marxist materialist viewpoint, argued that humans are part of nature, and that human thought stems from the material world. In fact, Engels provided a utilitarian and instrumental interpretation of the religious movements, presenting the clerics as a non-homogeneous social group that sometime features in the feudal pinnacle and is sometimes part of the revolutionary peasant movement (see Engels' book, "Socialism: Utopian and Scientific" (1880), in which he indicated the material and concrete interests underlying any affiliation with religion). Both Marx and Engels may be said to have referred to the revolutionism hidden in religion as a phenomenon of the past that has no influence or importance in the modern class struggle. This determination was highly criticized, especially in the camp of Marxist sociologists. Thus, for example, Michael Lowy (1996, 2005) and John Molyneux (2008) criticized the fact that the two philosophers did not distinguish between the religious beliefs of people in imperialist countries and the beliefs of oppressed people, and that they did not make sufficient effort to analyze specific 
religious consciousness in order to understand the real human needs and the hidden psycho-social conditions that formed this religious consciousness.

Like Marx and Engels, Lenin maintained the same ambivalent attitude towards religion. In his essay "Socialism and Religion" (1905), he called for the use of rational methods of persuasion and pure ideological logic, using the press and other information materials to combat the exploitation of the masses under the influence of religion and clerics. As we know, Stalin intensified this war against religion, and during his time the Soviet Union knew a difficult history of political atheism (Dawkins 1993). However, as atheism rose so did the voice of small religious movements, until it was discovered that religion was part of the national identity in Gorbachev's time, thus the Orthodox Church took on the status of a public institution, regained control, and reduced the activities of the small religious movements through cooperation with the state (McAnulla 2012).

\section{The Communist Party in Mandatory Palestine and in Israel Historical Path Dependent Review}

Foundations (1919-1925): The roots of the Israeli Communist Party originated in the PKP - the Communist Party of Palestine (in Yiddish: Palestinishe Komunistishe Partei), and the roots of the latter are rooted in the MPS (Socialist Workers Party) that was founded by a group of activists who withdrew from the Poalei Zion (Workers of Zion) movement and its new organization, Ahdut HaAvoda (Labour Unity). This group withdrew because they regarded Poalei Zion as a movement that clung to bourgeois and capitalist elements and renounced its commitment to socialism (Vilner 1970, Dotan 1991). The first conference of MPS, held in Jaffa (in March 1919), was considered the first constituent assembly of the Socialist Workers Party and the First Congress of the Communist Party in Palestine. At this assembly, it was decided that this party would encompass all laborers in Palestine, regardless of their nationality (Jizmati 2015).

Beginning of the Arabization process (1925-1933): Although the Comintern (international union of Communist parties that was controlled by the Soviet Union) was aware that members of the PKP maintained an adequate level of Marxist awareness, and were willing to sacrifice themselves for realization of the revolution, it was suspicious their deviation to the right, their isolation within the "Jewish ghetto", and their contempt for the anti-imperialist spirit, and lacked confidence in the Arabs' ability to join the Communist camp (In 1928, the number of Arab workers in the party was thirty. see: Letter from the Comintern to the executive committee of the PKP, 7.12.1928, in Zehavi 2005: 147, see also Ben Zaken 2006). As a result of these suspicions, the Comintern sent a letter (November 26, 1929), in which it strongly criticized the PKP leadership and instructed them to immediately begin a process of Arabization (Zehavi 2005). Correspondence from the 1930s attests to the removal of Jews from leadership positions and their transfer to advisory positions to the Arab leaders (Najati Sidqi and Mahmud Al-Mughrabi were among the first communist PKP leaders to emerge among the Palestinian Arab population, despite their training, they did not last long in their new roles in the PKP leadership and were deported by the 
British in early 1931 . The deportation of the two created a leadership vacuum, see: Kabha 2018), and as a result, many of PKP Jewish members who did not accept the Arabization process left the party.

The process of Arabization (1933-1937): Under the warnings and harsh criticism of the Comintern (see letter from August 27, 1933. see Zehavi 2005 : 304-305) the European Jewish leadership was dismissed and replaced by two Jewish natives of Palestine (Meir Slonim and Simcha Tzabari) and a Palestinian Arab from Jaffa (Radwan al-Hilu). Under their leadership, the party's connection to the Arab increased, and the party was no longer isolated. The Arabization process was opposed by Jewish objectors and Trotskyist advocates. However, this opposition was marginalized with the outbreak of the October 1933 events, following the Wadi al Hawarith lands issue and the ensuing violent clashes between Palestinian demonstrators and British police forces. For the first time in the history of the British Mandate, the anger of the Palestinian masses was directed only against the authorities. The PKP saw these events as an opportunity to ride the anti-imperialist waves in order to strengthen the party's hold on the Arab populace. However, these efforts were unsuccessful due to the presence of national parties that filled the national-political void, the party's underground activities, and its partnership with Jews who were suspected by the Arabs (During the 1920s and until the outbreak of the 1929 riots, the British Mandate operated agents within the PKP in order to ascertain the Party's connections with the Communist International and the Arabs. see: Spiegel 2002).

The presence of Slonim and Tzabari alongside Radwan al-Hilu (at that time, he was also Simcha Tzabari's companion), symbolized an era of "demographic territoriality" and partnership between native Arabs and Jews rather than a colonial immigrant community. Such a reunification pushed aside the national problem and drew attention to the cultural aspect.

The Arab majority in the party's Central Committee (until 1939 the only Jewish committee members were Simcha Tzabari and Meir Slonim) and the joining of new Arab members (Amin Aref and Bulus Farah), completely rejected any right of Jewish settlement in Palestine. The expansion of the Jewish settlement following the Fifth Aliyah (fifth wave of Jewish immigration), Comintern support for violent struggle, the denial of the national right of the Jews, were all factors that widened the schism of national separatism within the party. The rift expanded even further with the outbreak of the 1936-1939 Arab revolt in Palestine, when the PKP presented itself as one of the leaders of the struggle and a supporter of the Arab Higher Committee, while Hebrew leaflets emphasized to give up the option of force so that the Jews would have some peace and quiet (Zehavi 2005: 355369). In fact, these conditions paved the way for the next inevitable stage - the split.

The national conflict that led to a split (1937-1943): After the 1936-1939 Arab revolt in Palestine, the Palestinian communists began to develop a policy that corresponded with the circumstances of their political reality. This was also aided by the Comintern's announcement (in its seventh conference, summer 1935) regarding its abstention from direct interference with the internal organizational problems of each branch. Once the centrality of the Comintern was diminished, 
conflicts immediately emerged between the PKP leaders from the two national groups. The background of the conflict was national and there were many factors that contributed to its eruption. Among these factors we may mention the national alliance with the moderate Zionist parties, initiated by Jewish communists in 1937; the harsh treatment of the Palestinian Arabs by the Mandate government, and at the same time, their lenient treatment of the Jews; the alienation and polarization that began to develop between the two national groups, which escalated in the wake of the Great Arab Revolt of 1936-1939; the national awakening and the development of the idea of a bi-national state on the part of the Jews with the end of World War II, etc. The conflicts continued until 1943 when the party was expelled from the Comintern due to its cooperation with the Histadrut in strikes and demonstrations. This led to the final split.

The split - The National Liberation League in Palestine (1944-1948): After the split, the Arab members of the Palestine Communist Party founded the National Liberation League in Palestine (uṣbat at-taḥīr al-wațaniyy fi filasținn). The Jewish members, led by secretary-general Shmuel Mikunis together with Meir Vilner and Esther Vilenska, continued to lead the PKP. In 1944 Simcha Tzabari and Meir Slonim established the Communist Educational Union - later known as the Hebrew Communists, which was a Zionist organization. Additional factions were established and most of these united after the establishment of the State of Israel to form Maki (The Israeli Communist Party) (Miron 2011: 68).

The leaders of the National Liberation League, established in January 1944, initiated Marxist study groups that were initially deployed in urban centers such as Jerusalem, Hebron, Acre, Haifa, and Nazareth. These groups became small cells that were mainly attended by intellectuals who constituted the core of the revolutionary proletarian consciousness (the Avant-garde) according to MarxistLeninist thought. The National Liberation League was formed at a time when Jewish immigration accelerated. This was also a period when the Zionist movement and the Histadrut urged the implementation of two goals: the "conquest of soil" and the "conquest of labor" from Arab hands. The league struggled against the "conquer of soil and labor" but at the same time emphasized its position, which was contrary to that of the traditional national movement headed by Mufti Haj Amin al-Husseini, especially in regard to the forming of relations with the Axis countries (Italy and Germany) during World War II (Al-Ittihad: September 10, 1944) .

The league discussed the Palestinian problem and even issued a detailed memorandum to the UN (in August 1947) in which it insisted that the Jewish problem should not be solved at the expense of the Palestinian problem. It stressed that the Palestinian problem is an issue of independence, of liberation of the land from imperialism and foreign domination. The league noted, in more than one document (see: The National Liberation League in Palestine: 19451948 - Three Historic Documents (2001). Fu'ad Nassar Center. (Ramallah, pp. 84-85), that its political activity will only take the form of unarmed struggle.

It is well-known that the UN resolution on the Partition Plan for Palestine (November 29, 1947) was adopted in the General Assembly with the surprising support of the Soviet Union. Since then, and throughout the 1948 Independence 
War, the league embarked on a campaign to persuade the Arab residents to agree to the Partition Plan; it also called upon Arab residents to hold onto the land and expel the Arab armies from the homeland. In this persuasion campaign, the league relied on the proclamation of Communist parties in Arab states, distributed in early May 1948. Later, when the sight of refugees, deportations, and killing were still evident, the leadership of the league convened (at the end of September 1948) and announced its return to the Israeli Communist Party - Maki.

1948 - onward - a joint bi-national party: After the establishment of the State of Israel, Maki's Jewish character and dominance became prominent: 700 of its 1000 members were Jews, and the party leadership was also entrusted to Jews. Gradually, however, Maki became a political body expressing the national protest of the Arab citizens. A large part of the Arab public identified with Maki because of its vehement opposition to the Zionist idea and its harsh criticism against Israel's policy and martial rule over the Arab population, and due to its platform of finding solutions to the socio-economic problems of the Arab population in Israel. As a political organization that operated within the legitimate framework of the Israeli parliamentary, Maki was able to build itself an image as guardian of the problems of the underprivileged minority. The communist platform on the issue of Arab nationality appealed to a large part of the Arab public in Israel and helped consolidate the party within this population. In May 1965, on the eve of Maki's 15th Conference, the Jewish-Arab partnership was once again divided into two groups: a Jewish faction and a faction that included both Jews and Arabs (the New Communist list - Rakah) .The main factor behind the split was ideological: the Jewish faction adopted a balanced approach towards the JewishArab conflict and recognized the existence of two national movements in the region (Zionist and Arab), while the opposing faction adopted a distinct pro-Arab approach. After the elections in November 1965, it became clear that Rakah had won three Knesset seats versus the searing defeat incurred by Maki, which won only one seat. The Israeli communist camp was split along ethnic lines: the Arab voters gave Maki less than 5\% of their votes, while $85 \%$ of them voted for Rakah. During this period, Rakah was the main factor in the political leadership of the Arab citizens of Israel. Rakah leaders were the main proponents of the Land Day demonstrations in 1976 and of its organization. They were those who led to the establishment of the Democratic Front for Peace and Equality (Hadash) in 1975. After 1977, Rakah was part of Hadash from the 9th to the 12th Knesset elections. In 1989 it changed its name again to Maki and remained part of the Hadash list (Rudinzky 2014).

As we have seen, along the historical path dependent that has been reviewed, the tensions surrounding national identity were the main issue in the history of the relationship between the two national groups (Arab and Jews). These tensions were enhanced by those resulting from the act of taking command and control. 


\section{Methodology}

From a microscopic approach (Laughlin et al. 2000; Lozano et al. 2008), this study examines the discourse of the Palestinian Arab activists and leaders who belonged to the Communist Party prior to the establishment of the State of Israel and continued to belong to it within the Israeli Communist Party. The research group consists of those Arab political leaders, intellectuals, authors, and journalists in the Communist Party who belonged to the political settings of the National Liberation League (1943-1947), Maki, Rakah, and Hadash (from 1948 until the end of the period studied, 1976). The study will relate to this distinct group as a group of public intellectuals who were given the opportunity to represent, embody, and express a message, outlook, approach, philosophy, or opinion to and for an audience (Said 1994).

Based on the framework posited by Antonio Gramsci (1971: 54), the research group is related to as a group of "organic" intellectuals, who similar to other Communists in the Middle East (see, for instance, the cases of Egypt: Ginat 2008, 2011, Iraq: al-Kaysi 2012, Syria, Lebanon and Sudan: Jazmati 2015) used the "politics of the street" as raw material, reformulated and reshaped it, and on this basis created an ideological mass that was presented in the public arena and contributed to the development of civil society and of the national movements (Bamyeh 2012, Said 1994). The study examined: a. the ideas they formulated for their audience (ideas reflecting social feelings and the audience's thoughts and wishes were not explored with regard to this study); $b$. use of religious messages as a way of influencing the insertion of these ideas.

Based on a qualitative approach that relies on analyzing textual content, which is a technique for the systematic identification of messages in a text and drawing valid conclusions in their broad context (Holsti 1968, Krippendroroff 2004), a thematic analysis and a critical discourse analysis were performed (Shanthi et al. 2015: 159).

Examination of the public discourse focused on "intersections", which are constitutive events related to the Palestinian Communist Party during the British Mandate and after the establishment of the State of Israel.

The analyses focused on opinion columns and articles published in AlIttihad (The Unity), the Communist Party organ in Arabic, between 1943-1967, correspondence between the party members and the Comintern, the Nidal al Shaab newspaper, which was the Party organ in Arabic in the years 1940-1943, and official publications during the period of the party's Arabization process in 19351937, that is, after the appointment of Radwan al-Hilu as secretary-general.

The underlying assumption of critical discourse analysis is that the text reflects the authors' ideological perceptions and, accordingly, the perceptions they wish to promote (Hart 2011). The thematic analysis intended to identify repetitive patterns in the text and to identify the motifs that characterize use of religious messages (Van Dijk 2003). While the critical analysis intended to examine the religious messages themselves, their contents and their targets (their use), special attention was given to linguistic components such as the selected vocabulary, the types of argumentation, metaphors, and images, polarity, 
repetitive use of words, hyperbole (exaggerations), etc. (Van Dijk 2003, Meyer 2001, Wodak 2001).

\section{Findings and Interpretation}

When the party (PKP) was under the control of a dominant Jewish bloc with an Arab minority, there were only few traces of RT by Arab communists (According to a letter dated January 1, 1933, the number of Arabs in the party was 150. see Al-Sharif 2006: 343). One of the many items of correspondence is a letter written in French under the pseudonym "Hassan". The author of the letter is unknown, but the use of French often indicates his identity as a nonArab writer. This letter was sent from the Central Committee of the Palestinian Communist Party on October 7, 1931 (Al-Sharif 2006: 322), and contained harsh criticism directed to the General Islamic Congress in Jerusalem. The congress, which was held to discuss the conditions in the Holy Places and the establishment of an institute for Islamic religion in Jerusalem, was given a reactionary description as intended to serve the British imperial forces. Obviously, this letter is not sufficient to reach a decision concerning the attitude of the Arab communists to religion or their use of RT in that era.

About the period of 1933-1937, during which the Arabization process began, one can learn from a letter of the Palestinian Communist Party to the national parties in Palestine (October 16, 1935). This letter (Al-Sharif 2006: 435), written in fluent Arabic (Unlike the previous period when letters were written in Russian, German, Yiddish, and more, only a few letters were written in Arabic and these were full of spelling and syntax mistakes), began with the Islamic preface "Peace, mercy, and blessings of Allah be upon you". The letter is replete with quotations from the Quran and appears to have been written by an educated Muslim communist who knew and was familiar with the contents of the Quran and was influenced by them. This letter came to the attention of the Communist Party in Syria, raised the wrath of its members, and compelled them to respond with a letter opposing the use of RT. The Syrian communists' protest against this letter can be interpreted as emanating from two main reasons: (a) The knowledge that a writing style filled with religious quotations would annoy the superiors in the Comintern; and (b) The desire to preserve the good relations between the Jewish communists and the communists of the Syrian and Lebanese parties (most of whom were Christians and Armenians, whom the Jewish communists helped establish their parties), as the letter was directed against the Jews in general and not against the Zionists as was customary. Al-Sharif 2006: 439) In response to this criticism, the Palestinian Arab communists replied in a letter to their Syrian party brothers saying that for communists like them, religion is the root of morality and it does not deter them. They explained that their use of RT was done in the knowledge that this terminology would affect the poor, which constitute the majority in Palestine ( Al-Sharif 2006: 440).

This letter leads to two conclusions: (a) The Palestinian communists used RT to connect with the masses, even if it came at the expense of their relations 
with the Jewish communists or communists in Arab countries; (b) They maintained their identity and demonstrated a high degree of religiosity.

Nevertheless, it seems that the use of RT was very restrained and was employed only in situations where the party sought to expand its influence among the masses. A review of the pamphlets of the party organ, Nidal al-Sha'ab, between 1940 and 1943, when the Arabization process was already established, shows complete abstention from any religious issue or use of religious quotations/ language that does not serve expanding the party influence among the masses. This can be interpreted as an aspiration of the Arab communists (most of the newspaper's writers, headed by the party's secretary-general, were Muslims who had been educated in the traditional Islamic culture) to present themselves as equal to the Jewish camp that was committed to the atheist character of Marxism, and that used no religious language, therefore almost no religious identity was evident among the Arab camp. It should be noted, that the Arab communists' reluctance to give up the religious motifs was not hidden from the eyes of the "atheists" in the Comintern at the time (The Palestinian press of that period reported the closure of two-thirds of the churches in Russia. At the beginning of 1930, 540 churches, 18 mosques, and 63 synagogues were reported closed in a period of two months (see Al-Karmil Newspaper, January 9, 1930). The correspondence between Nadav, the contact person of the Palestinian Communist Party (PKP), who was a Jew, and the Central Committee of the Comintern from March 10, 1930, is one interesting example. In this correspondence, Nadav reports on taking the opportunity when Gazan Muslim communist intellectual Hamdi al-Husseini went on a pilgrimage to Mecca to hold meetings and create contacts with national elements in neighboring countries (Al-Sharif 2006: 260). Tepper (a Jew from the PKP) also discovered that the return of the Hejaz railway to Muslim hands made it possible to send propagandists from Russia to Mecca during the pilgrimage in order to spread propaganda, mainly about class issues such as working hours and the just distribution of lands to peasants (see: letter from March 8, 1927, in Batatu 1978: 386).

Between 1943 and 1948, the party was mono-national, and the Christian members took over the leadership of the National Liberation League. These leaders completed their high school studies at missionary schools(Apart from Bulus Farah and Fuad Nassar, who did not graduate from high school, the other four Christian founders, Hanna Nakara, Emile Touma, Tawfik Toubi, and Emil Habibi graduated from the prestigious Bishop Gobat High School in Mount Zion, Jerusalem). The Christians in Palestine at that time numbered at about $140,000(8 \%$ of $1,750,000)$ and therefore this leadership turned to increased use of RT deriving from Islam, with the aim of (a) blurring Christian religious affiliations; and (b) presenting themselves as contained within the Muslim majority, without giving up their religious identity. The Christian leaders, who were educated intellectuals, were aided by the cultural atmosphere and the local customs and traditions, the literature in which they were raised and educated, and the press, all of which were enriched by an atmosphere that was based on Muslim religious culture. 
Table 1. Use of RT by Historical Periods

\begin{tabular}{|c|c|c|c|c|}
\hline & $\begin{array}{l}\text { Before the } \\
\text { Arabization Process }\end{array}$ & $1935-1943$ & $1943-1948$ & $1948-1967$ \\
\hline Degree of use & Rare & Restrained & Massive & Massive \\
\hline Leadership & Jewish & Muslim secretary general & $\begin{array}{l}\text { A group of Christian intellectual leaders } \\
\text { in the Arab bloc }\end{array}$ & $\begin{array}{l}\text { A bi-national Jewish and Arab party; in the } \\
\text { Arab bloc the leadership was Christian and } \\
\text { later joined by Muslims as well. }\end{array}$ \\
\hline Goal of use \#1 & & $\begin{array}{l}\text { Receiving legitimacy and } \\
\text { competing for leadership } \\
\text { with other national parties. }\end{array}$ & $\begin{array}{l}\text { Integration: blurring the ethnic } \\
\text { (Christian) affiliation and integrating the } \\
\text { Christian minority into the Muslim } \\
\text { majority. }\end{array}$ & $\begin{array}{l}\text { Integration: blurring the ethnic (Christian) } \\
\text { affiliation and integrating the Christian } \\
\text { minority into the Muslim majority. }\end{array}$ \\
\hline Goal of use \#2 & & $\begin{array}{l}\text { Recruiting members from } \\
\text { the poor masses }\end{array}$ & $\begin{array}{l}\text { Legitimacy: removing the demon of } \\
\text { atheism, presenting the Soviet Union as a } \\
\text { liberal power that supports religious } \\
\text { freedom. }\end{array}$ & $\begin{array}{l}\text { Legitimacy: implanting the party as a } \\
\text { national party that grew from the workers' } \\
\text { movement, as opposed to the bourgeois } \\
\text { national movement that ruled before } 1948\end{array}$ \\
\hline Goal of use \#3 & & & $\begin{array}{l}\text { Dominance: A covert competition } \\
\text { between the national and religious leader } \\
\text { Haj Amin al- } \\
\text { Husseini and Stalin }\end{array}$ & $\begin{array}{l}\text { Dominance and control: creating an image } \\
\text { of an impostor and a traitor for the national } \\
\text { and religious leader, Haj Amin al-Husseini. }\end{array}$ \\
\hline Goal of use \#4 & & & $\begin{array}{l}\text { Coronation of a supreme leader: placing } \\
\text { Stalin as the head of a super-power and } \\
\text { as commander of an army that guards the } \\
\text { interests of the Muslims and the } \\
\text { establishment of world justice. }\end{array}$ & $\begin{array}{l}\text { Coronation of the Soviet Union as } \\
\text { bequeathing universal justice and as } \\
\text { fighting the reactionary dominating forces } \\
\text { and the forces of imperialism. }\end{array}$ \\
\hline Goal of use \#5 & & & $\begin{array}{l}\text { Softening and silencing objections on } \\
\text { ethnic or social status grounds within the } \\
\text { party }\end{array}$ & $\begin{array}{l}\text { Justifying the support for the partition } \\
\text { plan and legitimizing the existence of the } \\
\text { State of Israel }\end{array}$ \\
\hline $\begin{array}{l}\text { consolidation } \backslash \\
\text { bridging }\end{array}$ & & $\begin{array}{l}\text { Ethno-national consolidation } \\
\text { and maintaining a bridge } \\
\text { between the two } \\
\text { nationalities. }\end{array}$ & $\begin{array}{l}\text { Ethno-national consolidation: } \\
\text { Palestinian, Arab; Cosmopolitan bridge } \\
\text { to the Muslim space that is connected to } \\
\text { the Russian superpower; Cosmopolitan } \\
\text { lateral bridge to the Communists in the } \\
\text { Soviet Union and its allies. }\end{array}$ & $\begin{array}{l}\text { Consolidation within and bridging between } \\
\text { three systems: the Palestinian-Arab ethno- } \\
\text { national system; the broad system of the } \\
\text { Arab and Jewish binational party; the } \\
\text { cosmopolitan system which identifies with } \\
\text { communism. }\end{array}$ \\
\hline
\end{tabular}


The height of the use of religious language by Arab communists in Mandatory Palestine at the time was embodied in their decision to open the first issue of their newspaper, Al-Ittihad (May 14, 1944), with a headline that was a verse from the Quran - the holy book of Islam(The headline of the first newsletter was taken from Sura Al-Ra'ad, verse 17, and reads "As for the foam, it vanishes, [being] cast off; but as for that which benefits the people, it remains on the earth"). Also, in the festive newsletter of the second year (May 13, 1945), the same verse from the Quran was featured in the editorial headline. Similarly, the opening of their third-year festive newsletter (May 1, 1946), signed by Christian communist Emil Habibi, also had a religious flavor; the second Muslim caliph, Umar ibn alKhatțāb, is quoted as swearing to the god of the Kaaba (the holy place in Mecca) to lead his Muslim nation to the safe road.

Careful examination of the newspaper's leaflets (years 1943-1948) indicates that the contents of the articles lacked RT unless it was carrying a democratic sociological value that conformed to the values of communism. In addition, a review of the bulletins easily shows that emphasizing religious identity was a tool by which the Arab communists on one hand kept the atheist demon attached to the communist thinkers and the party leaders at a distance, and on the other hand touched emotional and sentimental chords among the believers sought by the Communist Party. Emile Touma, the Palestinian Christian intellectual from Haifa, can be held responsible for the decision to open the first issue of the Al-Ittihad newspaper with a quote from the Quran. Touma, as the newspaper's owner and editor-in-chief, also chose to report in this bulletin on the visit of the secretary of the Russian embassy in Cairo, Abd al-Rahman Soltanov, to Jerusalem (in May 6, 1944), where he was given a tour of the AlAqsa Mosque and the Supreme Islamic Council. This report had no other purpose than to encourage Muslims to join the party, with the emphasis that the Soviet Union is represented by devout Muslim representatives. This mantra repeated itself in many other reports.

It is interesting to raise one other point that relates to the desire of the Arab communists to emphasize and display the top leadership and the party's philosophers as "prophets" of a just and egalitarian world, while religious leaders have not succeeded in doing so. During the British Mandate, the head of the ruling national leadership, Haj Amin al-Husseini, was both a religious and a national leader. In an ambivalent manner, the Arab communists presented the atheist leader of the Soviet Union - "Stalin", as someone who had been crowned by the Muslim monotheistic believers. The bulletin dated June 8, 1944 brought a letter from the conference that had been sent by the Muslim representatives of Armenia, Azerbaijan, and Georgia to "Marshal Stalin". In the letter, they stressed their love to the motherland and their loyalty to their leader Stalin and called upon all Muslim believers to join the Red Army in its "holy war" against Hitler and the Nazis. It should be noted that, frequently and repeatedly, the communists were not deterred from using biased reports and distorted facts in order to present Lenin and Stalin as the leaders of justice entrusted with world order - especially the order in the Islamic world. The bulletin from January 4, 1945 published Lenin and Stalin's manifest, dated to the period of the Red Revolution and published in the Pravda 
newspaper (December 5, 1917). In this manifest, aimed at Muslims in Russia and in the East, Turkey, India, and other countries, Lenin and Stalin announced that after the revolution the injustice will end, there will be no more destructions of mosques and temples, freedom of belief will not be prevented (as conducted by Tsarist Russia), and national rights will be granted - something that contradicted the truth and the reality.

The league also used RT to silence any opposition to its action. The main article of a bulletin from January 14, 1945, includes a description of a comprehensive conference held for all representative offices of the Arab organizations, committees, and movements in Palestine, in which serious disagreements around the selection of delegates to the International Congress in London were reported. At the end of the conference, an agreement was reached to select three representatives: Sami Taha, who was a Muslim and well connected to the Histadrut and the British government; Hanna Asfur, who was Christian and was chosen with the intervention of the Histadrut; and Bulus Farah, who was Christian and one of the leaders of the National Liberation League. A review of pamphlets related to the conference shows that many of the other representatives protested against the choice of Bulus Farah, both because his religious identity and because of his social status. RT was immediately employed, and from within the league and through its journal it was a Muslim, Muhammad Bader Al-Din alKhatib, who scolded the other Muslim representatives, protesting the selection :"On the pilgrimage to Mecca, where you were all present, you were all in homogenous outfits and in one class, with no difference; you were all equal except for the amount of darkness within you as human beings [...] The evil spirit biases the spirit of a human being so that he can only see the difference between people and not the human unity".

The period after joining Maki in 1948: After the establishment of the State of Israel and after the communists joined the Israeli Communist Party (Maki) in late September 1948 (see declaration in Al-Ittihad: October 18, 1948), three factors were added that led the communists to use religious language: The agreement on the Partition Plan despite their strong opposition to it before the party supported the resolution; The agreement to grant the right of self-determination in the form of a state for the two nationalities, without considering the consequences of such recognition; The establishment of the Jewish state (Israel) and the nonestablishment of the Palestinian Arab state. These three prominent factors forced the Palestinian communists to be present as consolidating agents within their ethno-national sub-system, while at the same time as mediators within the broad system of the bi-national party. In and between the two systems, RT was used as a consolidating tool and/or as a mediating tool. Within a short period of time, the Arab party members became part of the United Party (Maki) and were joined by immigrant Jews who came from Arab countries, mainly Iraq, who spoke and wrote in Arabic and soon became partners in decisions about contents published in the communists party newspaper (see Kabha 2006 2018). At that time, Al-Ittihad also served and connected the Jewish immigrants who came from Arab countries and who had not yet mastered the Hebrew language. 
Use of RT in the period of 1948-1967 now had new goals. (a) Emphasizing the pan-Arab sentiment, embraced by the Russian superpower; (b) Mediating between Arabs and Jews under a cosmopolitan communist identity; (c) Granting legitimacy to the State of Israel; (d) Bypassing a direct confrontation with forces from the Jewish right-wing and joining forces with the Jewish left-wing. These sub-goals can be grouped together to form one overall purpose: The use of religious terminology (RT) as a consolidating tool in and between the three systems: the Palestinian Arab ethno-national system; the broad system of the binational party; and the wide cosmopolitan system headed by the Soviet Union.

Immediately after joining Maki (Emil Habibi's speech on October 22, 1948), the communists in leadership positions, mostly Christians, made sure to highlight their movement as a national liberation movement whose leadership had grown from the ranks of the working class, while presenting the Palestinian national leadership before 1948 as a bourgeois movement that had taken control of the people. Now that the dominant traditional national leadership from before 1948, mostly Christians as well, was outside the borders of the Jewish state, leaving the political and national space almost empty, the experienced communists immediately took a stand and placed themselves as responsible and as speakers on behalf of the Arabs who remained within the borders of the State of Israel. They used RT to assume the position of national patrons, in order to justify their consent to the Partition Plan, as opposed to the disaster inflicted upon them by the Mufti, who had joined Hitler and refused to agree to it (Al-Ittihad: March 10, 1967). Regarding the national disaster and loss of the homeland that had befallen their people, the Arab communists now connected with the Jewish camp within the party, made sure not to place any responsibility on the newly established Jewish state, and instead blamed the reactionary forces of Anglo-American imperialism and the Arab states that had allied with them (Al-Ittihad: November 8, 1948).

As in the previous period, the Arab party leaders of the Israeli Communist Party tried to distance themselves from the ethnic affiliation and from their connection to the church. In the first page of the November 1948 bulletin, we can find the Arab communists' strong opposition to the joining of the Clergy from all Christian communities for the establishment of the Nazareth Workers' Union that organized workers according to their communal affiliation. The communists continued to highlight this issue in the following bulletins as well, criticizing religious leaders and questioning their integrity and efforts (Al-Ittihad: October 25, 1948). In order to emphasize the distancing of the ethnic demon, the communists also elaborated on the rumor that the city of Nazareth, similar to Jerusalem, would become an area under international supervision because it is a holy city for Christians (Al-Ittihad: December 26, 1948):

\footnotetext{
"The transformation of Nazareth (according to the Partition Plan, was to be part of the Arab state) into an international zone puts it under the control of Anglo-American imperialism. [...] The relations between the residents will be based on ethnic and religious discrimination and there will be a separation between Nazareth and the surrounding villages [...] We are fighting for the establishment of an independent and democratic Arab state, of which Nazareth will be part".
} 
However, avoidance of identifying with the Church had not always been maintained, especially when it served the interests of the communists themselves. For example, the party's newsletter emphasized the restoring of relations between the Orthodox Church in Palestine and Israel and the Soviet Union. In this case, religious faith connected the three entities: the Palestinians in Israel and in the area that was under the control of Jordan and Egypt, the State of Israel, and the Soviet Union (Al-Ittihad: December 13, 1948).

The Arab communists in Israel continued to portray the superpower as a guardian of religious freedom and the holy places, and as very far from atheism. More than once, they emphasized the visits of Russian Muslim clerics on their pilgrimage to Mecca, and also their visit to Egypt and the surrounding Arab countries ( ${ }^{*}$ see, for example, Al-Ittihad: Bulletin from September 23, 1955). There were also reports of Christian Arab delegations attending congresses held in the territory of the Russian superpower, who used their visits to attend Sunday and public services in the Russian Orthodox churches. Thus, for example, there was a report of a visit of a delegation from Israel in a cathedral in Sofia, capital of the People's Republic of Bulgaria, on October 28, 1955, and on gifts that were given by the Bishop to the Orthodox Church in Nazareth.

A review of texts in the newspapers reveals that RT played a role in legitimizing the existence of the State of Israel and in calling upon Arabs in the surrounding countries to maintain peaceful relations with it. The October 18, 1955 bulletin included an article with the heading:

"Cairo - One of the reporters asked a senior official in the Islamic al-Sharia, sheikh Abd al-Wahhab Khalaf, whether the laws of Islam prohibit a peace agreement with Israel, and the sheikh replied in the negative".

The above news gives some legitimacy, coming as it did from a leading country where nationalism and Arabism were flourishing under the patronage of Gamal Abdel Nasser, and not only that, it emanates from a city that symbolizes Al-Azhar, which is a respected source of the Sharia - the Islamic legislation.

In circumstances in which national sentiments arose, especially in times of war and direct confrontation between Israel and the Palestinians and/or the neighboring Arab countries, and against the background of the policy of discrimination and oppression by the government towards its Arab citizens, the communists used religious terminology (RT) in order to soften the confrontation and mediate between the Arabs and the Jewish Right, and to mobilize the Jewish Left to support the Arab struggle against the government and its policy. In this context, we may present the example of the Kafr Qasim massacre, carried out by an Israeli Border Police unit on October 29, 1956, during which 49 residents of the village were shot dead. Following this incident, the communists mobilized Yeshayahu Leibowitz's (in his religious thought he held that the essence of Judaism was practical commandments (mitzvot), and not faith) letter to the Ha'aretz newspaper. Leibowitz was an Israeli Orthodox Jewish intellectual and polymath who demanded that the soldiers who had committed the massacre be judged the same way Nazi soldiers were sentenced following the massacres they committed against Jews (Al-Ittihad: October 31, 1958). 
"Our country is the land of return and prophecy and is considered a lighthouse for the rest of the nations. There is no doubt that my proposals will find positive echoes among the readers. The redemption of Zion will be done only by good deeds and justice".

The above quotation is an example of cases where RT was used to emphasize rights and elimination of injustice, and especially as a tool for mediating between the Jewish majority and the Arab minority. The same phenomenon was observed in every incident of confrontation with the Israeli military or police forces, in which national sentiments arose among the Arab residents of Israel.

It should be noted that, at that time, the party's interests also set the tone and the relations between the two national groups, the Arab and the Jewish. The support for the Partition Plan by the Arab communists, after initially rejecting it, clarifies the fundamental significance of loyalty to the leadership of Soviet Union by the communists at that time and subsequently.

\section{Conclusions}

Throughout this paper, religious terminology (RT) was presented as a powerful tool that Arab communists could use, although they advocated an ideology of scientific atheism that was promoted by the Communist Party's ideological thinkers and leaders.

In an Islamic Middle East, where minorities enjoyed freedom of faith and worship, the secular atheism of Marxism did not penetrate the minds of the Arab communists in Mandatory Palestine and later in Israel; not even of those who had completed their academic studies at the Communist University of the Toilers of the East (КУТВ) in Moscow. Their religious education and culture prevented them from connecting to scientific atheism but did not prevent them from joining communism in the sense of practically realizing the religious values of social justice.

The Comintern, which promoted scientific atheism, together with the Palestinian Communist leaders, was aware of the fact that it would be hard to instill any modern or revolutionary socialism among a population of believers if it were to lack recognition of and reliance on religious foundations. For this reason the Arab communists, with the approval of the Comintern, often emphasized their religious identity and affiliation, in order to remove the atheist demon that clung to the ideology and to the superpower under which their party acted, and thereby succeed in advancing their political, class, and national interests. Nevertheless, throughout the party's different incarnations, total avoidance was practiced with regard to providing a platform for any religious discussion or emphasis of any religious orientation.

The Palestinian Arab communists knew that RT is a powerful tool that strikes emotional and sentimental chords among the masses. Therefore, they used it as a tool for national engineering; as a basis for establishing Communist ideology and instilling a Marxist education among the masses; to crown the Soviet Union and its leaders, instead of the religious leaders, as custodians of world order; to 
obtain legitimacy vis-à-vis the competing national parties; and to consolidate their status and attract the masses to the bosom of the party; to regulate relations within the party, including silencing any vagaries of opposition on the basis of ethnicity or social status; to blur any differences in religious identity of the Christian minority within the Muslim majority; to meditate and consolidate between and within the three systems: the Palestinian Arab ethno-national system, the broad system of the Arab and Jewish binational party, and the cosmopolitan system that identifies with communism.

The study showed that the use of RT played an ambivalent role in consolidating the Palestinian Arab collective under the ethno-national identity and in mediating with the communist Jewish collective, under the lateral cosmopolitan communist identity. Use of RT for the purpose of ethno-national consolidation was more direct and open, at a time when the Arab communists were free from partnership with the Jews within the party (in the Arabization period and the National Liberation League period) and more restrained and indirect during other periods, in which the Jews controlled the party (before the Arabization, and during the Maki period). The use of RT to consolidate with the communist and non-communist Jewish collective became more massive in circumstances when there was a need to ask the Arab masses' legitimization for joining a party with Jewish partners. Moreover, the frequency of the ambivalent use of RT as a tool for consolidating and mediating between the two ethnonational groups (the Arabs and Jews in Israel) increased when national sentiments became prominent against the backdrop of a direct national confrontation between the two collectives.

The study also showed that the Palestinian Arab communists adapted the use of RT to the circumstances of each period, which can be separated according to significant junctions (the establishment of the party; the Arabization process, the split of the party, the acceptance of the Partition Plan, the 1948 war, and the joining of the Israeli party), and as a response to the events of previous junctions. The following components dictated the change in the purpose of RT use between one junction and the next: the balance of power and relations with the Jews within the party and the composition of the party (bi-national/mono-national); the ethnic composition of the leadership; the competing forces of the traditional national movement; the policy of the Soviet Union regarding the relations within and outside the party; the strength and interests of the Soviet Union and its presence in the global space and in the surrounding Arab space; and the prominence of national sentiments in a time of confrontation or of direct or indirect war between the two national camps - the Arabs and the Jews.

\section{References}

Abu Khalil A (2009) Arab Communism: Some Reasons for Its Fall (Arabic). Angry Arab News. Retrieved from https://al-khbar.com/Archive_Articles/145790. [Accessed 13 January 2019].

Al-Karmil Newspaper. (Was a bi-weekly Arabic-language newspaper founded toward the end of Ottoman imperial rule in Palestine). The National Library of Israel. Retrieved 
from http://web.nli.org.il/sites/nlis/ar/jrayed/pages/press03-2017.aspx [Accessed 13 January 2019].

Al-Kaysi S (2012) The History of the Communist Party in Iraq from Fahd's Execution until the Revolution of July 14 1958. Damascus: Dar al-Hasad (Arabic).

Al-Sharif M (2006) Palestine in the Secret Archive of the Comintern. Damascus: Al Mada Publishing House (Arabic).

Appleby S (2012) Religious Violence: The Strong, the Weak, and the Pathological. Practical Matters 5: 1-25.

Baldwin D (1989) Paradoxes of Power. New York: Basil Blackwell.

Bamyeh M (2012) Intellectuals and Civil Society in the Middle East: Liberalism, Modernity and Political Discourse. London: I.B. Tauris.

Batatu H (1978) The Old Social Class and The Revolutionary Movement in Iraq. Princeton, NJ: Princeton University Press.

Ben-Zaken A (2006) Communism as Cultural Imperialism: The Affinities between EretzIsraeli Communism and Arab Communism 1919-1948. Tel-Aviv: Resling (Hebrew).

Dawkins R (1993) Viruses of the Mind. In B Dahlbom (ed) Dennett and His Critics: Demystifying Mind, 13-27. Hoboken NJ: Blackwell.

Dotan S (1991) Reds - The Communist Party in Eretz Yisrael. Kfar Saba: Shevna Hasofer (Hebrew).

Engels F (1880) Socialism: Utopian and Scientific. MECW Volume 24, pp. 457-9. First published: in F. Engels, Die Entwicklung des Sozialismus von der Utopie zur Wissenschaft, Hottingen-Zurich, 1882.

Engels F (1886) Ludwig Feuerbach and the End of Classical German Philosophy. In: Foreign Language Press Peking (1976). http://www.marx2mao.com/M\&E/LF86.ht $\mathrm{ml}$. [Accessed 13 January 2019].

Fox J and Sandler sh (2004) Bringing Religion into International Relations. Culture and Religion in International Relations. New York: Palgrave Macmillan.

Fox J S (2018) An Introduction to Religion and Politics: Theory and Practice, $2^{\text {nd }}$ ed. New York: Routledge.

Froese P (2004) After Atheism: An Analysis of Religious Monopolies in the PostCommunist World. Sociology of Religion, 65(1): 57-75.

Froese P (2005) I Am an Atheist and a Muslim: Islam, communism, and ideological competition. Journal of Church and State 47(3): 473-501.

Ginat R (1996) Soviet Policy towards the Arab World, 1945-1948. Middle Eastern Studies 32(4): 321-335.

Ginat R (2008) Stages in the History of the Communist Movement in Egypt: The Jewish Perspective. Hamizrah Hehadash 47: 155-187 (Hebrew).

Ginat R (2011) A History of Egyptian Communism: Jews and Their Compatriots in Quest of Revolution. CO: Lynne Rienner Publishers.

Gramsci A (1971) Selections from the Prison Notebooks of Antonio Gramsci. New York: International Publishers.

Hart Ch (2011) Moving beyond Metaphor in the Cognitive Linguistics Approach to CDA: Construal Operations in Immigration Discourse. In: Hart, Ch. (Ed.), Critical Discourse Studies in Context and Cognition: 171-192. Amsterdam: John Benjamins.

Holsti O (1968) Content Analysis. In: Lindzey, G., Aronson, E. (Eds.), Handbook of Social Psychology, 2 : 596-692. Reading, MA: Addison-Wesley.

Jizmati N (2015) The History of the Arab Communist parties. Damascus: Dar Ninawa (Arabic).

Kabha M (2006) The Arab Press in Israel 1948-2006, as an Apparatus in the Identitybuilding Process. Sectoral Communication in Israel. Tel-Aviv University: Herzog Institute of Communications (Hebrew). 
Kabha M (2018) The Life of Jewish Immigrants from Muslim Countries in the Transit Camps as Reflected in the Arabic Journalistic Discourse in Israel, 1950-1967. Israel Studies at 70, Special Issue: Version and Reality 23(3): 123-131.

Krippendorff K (2004) Content Analysis: An Introduction to Its Methodology ( $\left.2^{\text {nd }} \mathrm{ed}\right)$. Thousand Oaks, CA: Sage.

Laughlin R, Pines D, Schmalian J, Stojkovic J, Wolynes P (2000) The Middle Way. PNAS 97(1): 32-37.

Lenin V (1905) Socialism and Religion. Collected Works 1965(10): 83-87.

Lozano S, Arenas A, Sanchez A (2008) Mesoscopic structure conditions: the emergence of cooperation on social networks. PLOS ONE 3(4): e1892.

Lowy M (1996) The War of Gods: Religion and Politics in Latin America. London-New York: Verso.

Lowy M (2005) Opium of the People? Marxism and Religion. International Viewpoint. Online Magazine of the Fourth International. Retrieved from http://www.interna tionalviewpoint.org/article.php3?id_article=807. [Accessed 8 January 2019].

Marx K (1844) Contribution to the Critique of Hegel's Philosophy of Law. in Karl Marx and Frederick Engels, Collected Works, volume 3. Retrieved from www.marxists. org/archive/marx/works/1843/critique-hpr/. [Accessed 8 January 2019].

McAnulla S (2012) Radical atheism and religious power: new atheist politics. Approaching Religion 2(1): 87-99.

Meyer M (2001) Between theory, method, and politics: positioning of the approaches to CDA. In R Wodak, M Meyer (eds) Methods of Critical Discourse Analysis. London: Sage McClelland.

Miron L (2011) A Red Star in the Israeli Flag: The Communist Movement in Eretz Israel and its Attitude Towards Zionism During the Yishuv and the First Decades of Independence. Jerusalem: The Hebrew University, Magnes Press (Hebrew).

Molyneux J(2008). More Than Opium: Marxism and Religion. International Socialism 119. Retrieved from www.isj.org.uk/?id=456. [Accessed 8 January 2019].

Rudnitzky A (2014) Arab Citizens of Israel Early in the Twenty-First Century. Tel-Aviv: The Institute for National Security Studies (Hebrew).

Said E (1994) Representations of the Intellectual. The 1993 Reith Lectures. New York: Pantheon Books.

Shanthi A, Kean Wah L, Laijum D (2015) Discourse Analysis as a Qualitative Approach to Study Information Sharing Practice in Malaysian Board Forums. International Journal on E-Learning Practices (IJELP) 2: 159-169.

Spiegel Y (2012) Agents of the criminal investigations department (CID) in the communist party. Iyunim Bitkumat Israel 12: 271-2.

Van Dijk T.A (2003) Critical Discourse Analysis. The Handbook of Discourse Analysis. 18: $352371 \mathrm{~W}$.

Vilner M (1970) 50 Years of the Communist Party in Palestine/Israel. Tel-Aviv: Central Committee, Communist Party of Israel (Hebrew).

Wodak R (2001) What CDA is about: a summary of its history, important concepts and its developments. In R Wodak, M Meyer (eds) Methods of Critical Discourse Analysis, 1-13. London: Sage.

Wright E (1978) Class, Crisis, and the State. London: New Left Books.

Zahavi L (2005) Apart or Together: Jews and Arabs in Palestine according to the Documents of the Comintern (1919-1943). Tel-Aviv: Keter Books (Hebrew). 


\section{$\underline{\text { Archives }}$}

Memorial and Heritage House archive, Nazareth, Israel (2019).

The National Library of Israel. Retrieved from https://bit.ly/2JnmbPZ [Accessed 8 January 2019]. 